Portland State University

PDXScholar

1984

\title{
Spies in America : German espionage in the United States, 1935-1945
}

Joan Irene Miller

Portland State University

Follow this and additional works at: https://pdxscholar.library.pdx.edu/open_access_etds

Part of the European History Commons, and the Military History Commons Let us know how access to this document benefits you.

\section{Recommended Citation}

Miller, Joan Irene, "Spies in America : German espionage in the United States, 1935-1945" (1984). Dissertations and Theses. Paper 3579.

https://doi.org/10.15760/etd.5463

This Thesis is brought to you for free and open access. It has been accepted for inclusion in Dissertations and Theses by an authorized administrator of PDXScholar. Please contact us if we can make this document more accessible: pdxscholar@pdx.edu. 
AN ABSTRACT OF THE THESIS OF Joan Irene Miller for the Master of Arts in History presented October 26, 1984.

Title: Spies in America. German Espionage in the United States, 1935-1945.

APPROVED BY MEMBERS OF THE THESIS COMMITTEE:

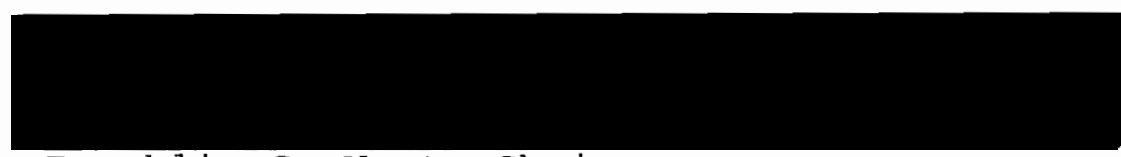

Franklin C. West, Chairman

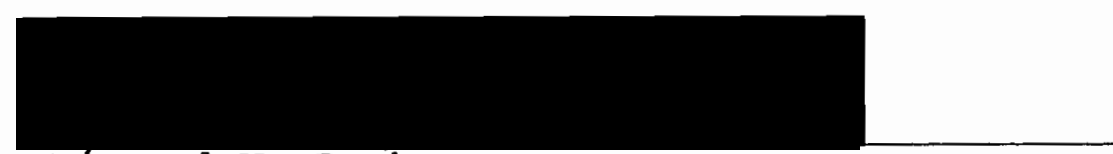
Bérnazd v. Burke
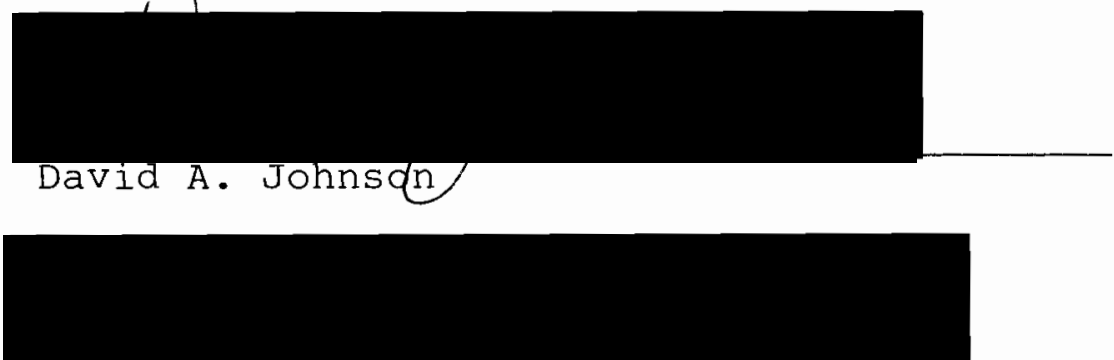

William B. Fischer

This thesis addresses the topic of German espionage in the United States between 1935 and 1945. It examines what the expectations were for Germany's spies in America, their activities, and the success or failure of their operations. In addition, the reaction of the American public to these spies is also studied, as well as the response to what was perceived as a threat to the United States from Nazi 
Research on this subject reveals that there were a number of German espionage agents involved in several different spy rings operating in the United States before Pearl Harbor. Information obtained by these individuals primarily concerned the transportation of war materials to the Allies, and America's industrial and military production. Much of the information sent to Germany was not of a highly classified nature and could be found in technical journals and publications, through verbal affirmation and visual sightings. Most of these individuals were arrested in the summer of 1941.

During the war years, German military intelligence attempted two separate missions involving three different landings of agents from submarines on America's Atlantic shores. All of these agents, a total of ten, were caught by the FBI before any spying or act of sabotage could be accomplished.

The available information and source data reveals that German espionage operations in America were replete with mistakes, bad organization, involved poor agent selection, and ultimately fulfilled few of the expectations of the Third Reich's spymasters. However, the beliefs held by many Americans concerning German spies and their operations, contradict what is seen now as the overall failure of German spying in the United States. This was due in part to the media--newspapers, magazines, nonfiction books, popular fiction, and Hollywood movies--which exaggerated and 
sensationalized the danger presented by Nazi espionage agents in America. For much of America, the media reinforced an image of the insidious but resourceful Nazi spy, and suggested accomplishments far exceeding their actual performance and success. Thus there was a great difference between what many American's believed, and the true achievements of German agents and their operations in the United States.

Primary sources valuable in the production of this paper include the volumes of Documents on German Foreign Policy, statements pertaining to individual agents, spy rings and sabotage operations furnished by the Federal Bureau of Investigation, and the vast microfilm collection of German records seized following the end of World War II held by the National Archives. Also used were personal memoirs, information compiled and released by the U.S. Navy's Office of Naval Intelligence, the volumes of the Trial of the Major War Criminals Before the International Military Tribunal, and the 1938-1945 volumes of Foreign Relations of the United States: Diplomatic Papers.

Important secondary sources include what proved to be the invaluable contemporary works written between 1935 and 1945 about the German espionage menace in America. These included not only nonfiction books, but magazine articles and news items from the New York Times. Also very useful were Heinz Höhne's excellent biography of Wilhelm Canaris, David Kahn's well-researched book on German military 
intelligence in World War II, and Ladislas Farago's the Game of Foxes. 


\section{SPIES IN AMERICA}

GERMAN ESPIONAGE IN THE UNITED STATES 1935-1945

by

JOAN IRENE MILLER

A thesis submitted in partial fulfillment of the requirements for the degree of

\section{MASTER OF ARTS}

in

HISTORY

Portland State University

(C) 1984 Joan Irene Miller 
TO THE OFFICE OF GRADUATE STUDIES AND RESEARCH:

The members of the Committee approve the thesis of Joan Irene Miller presented Cctober 26, 1984.

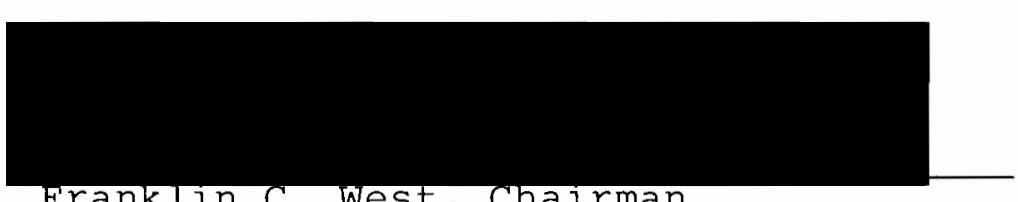

Frankin c. west, chaırman

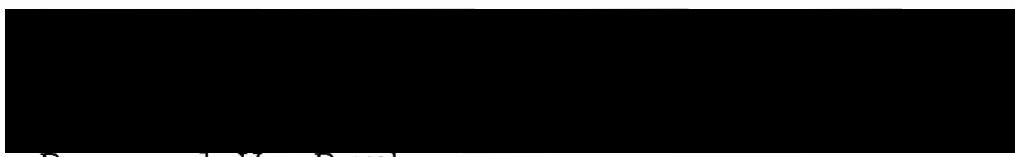

Bernard V. Burke

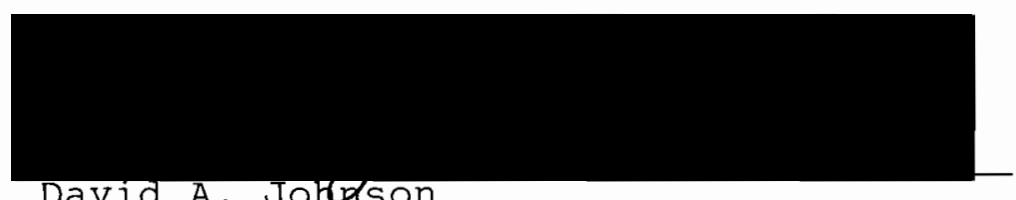

David A. Jorpison

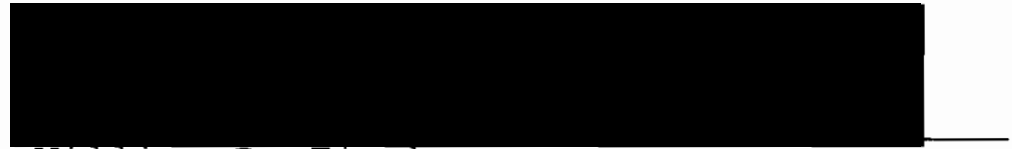

Willam B. Fischer

APPROVED :

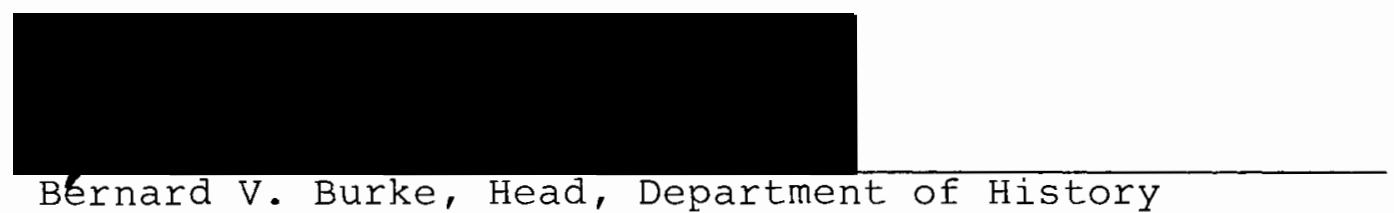

Bernard v. Burke, Head, Department of History

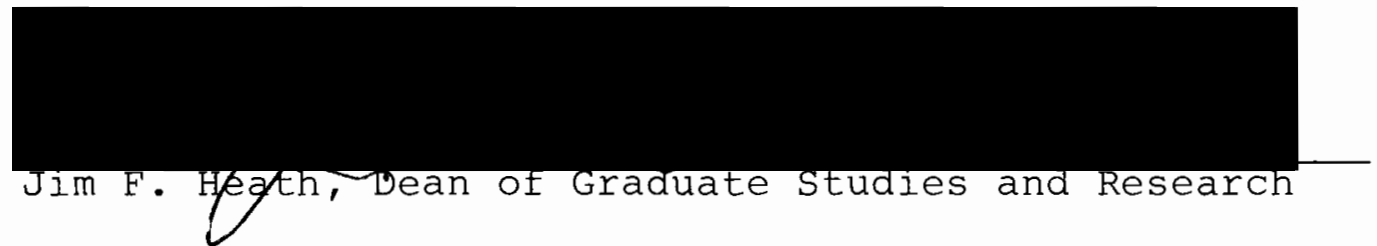


TABLE OF CONTENTS

CHAPTER

PAGE

I INTRODUCTION • • • . . . . . . . . . . . 1

I I THE STRUCTURE OF THE AMT/AUSLAND ABWEHR • • 5 NOTES FOR CHAPTER II . . . . . . . . 15

I I THE CRACK IN THE WALL . . . . . . . . . . 17

NOTES FOR CHAPTER III • • . • • • • • • 35

IV ANATOMY OF A SPY NETWORK . • • . . . . . . . 38

NOTES FOR CHAPTER IV . . . . . . . . 61

$V$ "THE GREATEST SPY ROUNDUP IN U.S. HISTORY" • 65

NOTES FOR CHAPTER V • . . . • . . . 79

VI OPERATION PASTORIUS • . . . . . . . . . . . 81

NOTES FOR CHAPTER VI • . . . . . . 120

VII THE FINAL REMNANT • . . . . . . . . . . . . 124

NOTES FOR CHAPTER VII • • • • • • • . 137

VIII A LAST EFFORT • • • • • • • • • . • • . . 140

NOTES FOR CHAPTER VIII • • • • • • . . 155

IX RESPICE FINEM • • • • • • • • • • • • • 157

NOTES FOR CHAPTER IX . . . . . . . . 169

A LIST OF WORKS CONSULTED • • • • • • • • • • • • • 170 
CHAPTER I

\section{INTRODUCTION}

Following World War I, the United States emerged as one of the great powers of the world. America's assistance to the Allies exemplified its capability in war. It also revealed the strength of the country's industrial capacity, which was certain to give it a decisive edge in future conflicts. Military intelligence operations--the gathering of sensitive information concerning the condition, resources, and plans of other countries--had long played a crucial role in the victory or defeat of nations. Because of its increased status and developed power, post-World war I America tempted many as a lucrative espionage target, particularly the military intelligence agents of Germany. Germany was at the end of the power scale from the United States. Having lost the war in 1918, it was at the mercy of what many Germans viewed as an extremely punitive peace treaty engineered by the victors. The Treaty of Versailles assigned Germany responsibility for the war, and for all the civilian losses and damage suffered by the victorious Allies. According to terms of the Treaty, Germany was to make monetary compensation for all the damage it had done, and was also required to forfeit to the Allies, large amounts of goods, including steel, coal, and timber. 
Its army and navy were limited to no more than token forces. The military air force was eliminated entirely. The manufacture of most offensive military weapons and equipment was forbidden. The Allies had refused to negotiate a peace settlement with the German military or the monarchy, except to demand unconditional surrender if these forces were not removed from power. In Germany, war-weary citizens demonstrated, demanding peace. Revolution erupted, culminating in the Kaiser's abdication and the declaration of a German Republic by the majority Socialist party. The German people had little experience or understanding of this democratic form of government, and most of the country's citizens disliked and distrusted the new Republic. Quite on purpose, Germany was reduced in power and authority by the Treaty and the victorious Allies.

This enforced reduction in status was difficult for many Germans to accept. The country's military leaders were particularly indignant. They formulated plans to evade the disarmament terms of the Versailles Treaty by secretly rearming and rebuilding Germany's military forces. Inevitably these plans led Germany's military intelligence organization to the United States. There its agents worked to gather information, designs, and samples to aid clandestine rearmament and buildup of the then illegal German air force.

By 1933, the National Socialists were in power in Germany and the fiction of disarmament was cast aside. In 
1935, Admiral Wilhelm Canaris was appointed head of Germany's military espionage and counterespionage organization--the "Amt Ausland/Abwehr"--and found a small cadre of agents already employed in the United States on behalf of the Abwehr. Ten years later, the Abwehr was essentially absorbed into the "Reichssicherheitshauptamt"--the Central State Security Bureau of the Nazi Party--or RSHA. Between Canaris' appointment and the fall of the Third Reich in 1945, German intelligence infiltrated the United States with additional agents and landed saboteurs on America's Atlantic shores. The effectiveness of these agents fluctuated widely between success and failure. But, irrespective of concrete results, Germany's intelligence agents and their espionage activities in the United States had a significant effect on America and its citizens. Public response to the specter of enemy agents was rarely dependent on what their work in America had actually produced. Instead, the reaction of many Americans was dictated by what they believed was the purpose and intention of Nazi spies in the United States. These beliefs, encouraged by the federal government, and enlarged on by the media, translated into an almost irrational fear of covert activities fostered by the "evil" Third Reich.

Consequently, there emerge two important questions regarding German espionage activities in the United States between 1935 and 1945. First, what did the intelligence 
agencies of Germany--the Abwehr and the RSHA--expect from their agents in the United States, and what was ultimately accomplished by these agents? Second, were the fears of Americans about German spies in the United States and the results produced by these spies contradictory? It may be, in the final analysis, that the effectiveness of Germany's espionage agents and the overall success or failure of German intelligence in the United States was of less consequence than what Americans believed. 


\section{CHAPTER II}

\section{THE STRUCTURE OF THE AMT/AUSLAND ABWEHR}

The German military intelligence system, which had operated since the days of Frederick the Great, was dismantled after Germany's defeat in World War I. However, it was almost immediately resurrected. The purpose of this intelligence service was ostensibly to combat leftist extremism and revolution within the new and unsteady Weimar Republic, and to counter attempts of foreign interference in German governmental operations. The clandestine aim of this revived intelligence group was to aid Germany in circumventing portions of the Versailles Treaty restricting foreign intelligence operations. The title of the new intelligence and reconnaissance service was "Abwehr" from the verb "abwehren," which means literally "to ward off or defend," a designation intended to camouflage the real purpose of the Abwehr--to spy for Germany.

Captain Wilhelm Canaris became the head of the Abwehr on January 1, 1935. Canaris was forty-eight years old when he took over the Abwehr. A career navy man, he entered the Imperial Naval Academy in 1905. He served on the light cruiser "Dresden" in World War I, until the ship was scuttled near Chile in 1915. Canaris first became involved in intelligence work in 1916, operating in Spain as an 
espionage director, choosing agents for assignments. He supported right-wing elements in the $1920^{\prime}$ s, and had no real loyalty to republicanism and the Weimar Republic. Canaris alternated duty on land and sea, rising to command the battleship "Schlesien" in 1932. However, in late 1934, Canaris received the dead-end appointment as commander of the naval station at Swinemünde, where he was supposed to serve out his days until retirement. (1)

It was Conrad Patzig, appointed head of the Abwehr in 1932, who recommended Canaris as his replacement. Patzig was fired, primarily because of his differences with Reinhard Heydrich, Heinrich Himmler, and the Nazi Party's security agency, which tended to encroach on spheres of operation assigned to the Abwehr. Patzig suggested Canaris' name to Admiral Raeder, and Raeder nominated him for the position in late 1934. Canaris was thought to be capable of handling the antagonism of the rival intelligence organization of the Nazi Party, the "Sicherheitsdienst des Reichsführers-SS," or SD, under Reinhard Heydrich. Heydrich, a former naval officer, had served under canaris when both men had been assigned duty on the cruiser "Berlin," and the two men maintained an outwardly friendly relationship until Heydrich's death in 1943. Heydrich was interested in expanding his own power base and wanted all intelligence services in the Third Reich to be put under his command. His SD was primarily concerned with political espionage and internal security, while the Abwehr was 
responsible for military intelligence and counterespionage. However, divisions between the two were often unclear, and competition and duplication were inevitable. The SD consistently attempted to interfere with the Abwehr's area of control, but Canaris was able to hold off Heydrich, and for a time maintained the Abwehr as an independent agency of the military outside the Party's jurisdiction.

Following his appointment as chief of the Abwehr, Canaris restructured and enlarged the agency. By 1939, what had been a six-department organization when Canaris took over in 1935 had been consolidated and centralized into three major operational groups; espionage, sabotage and counterespionage. In addition, the organization included a foreign information division and a central branch. Known collectively as the "Amt/Ausland Abwehr," by October, 1939, Canaris' intelligence service was the military's central agency for espionage, sabotage, and counterespionage, with all the powers of a full department of the "Oberkommando der Wehrmacht"--Armed Forces High Command--or OKW. (2)

As the Abwehr grew, Canaris found it increasingly difficult to supervise his intelligence organization. He was not interested in the bureaucratic paperwork necessary to run the Abwehr, and it was hard for him to delegate responsibility. (3) He preferred visiting the Abwehr field stations, where he could feel a part of the actual intelligence operations. To the consternation of his field commanders, he often issued instructions contradicting their 
basic policies, almost assuring chaotic upheaval at each of his visits. (4)

Canaris eagerly and personally sought new recruits for the Abwehr, often choosing them for their availability rather than their talent for intelligence work. His personal choices included military men, civilians, monarchists, vehement anti-Nazis, and avowed National Socialists. Many of Canaris' new recruits lacked the necessary experience to do their jobs effectively, and in-house training was limited. (5)

In part due to Canaris' poor personnel selection and his bad management skills, the Abwehr lacked political cohesiveness and needed a foundation of internal guidelines to insure and maintain quality. Inefficiency among personnel was never really controlled. While this may not have been detrimental in Canaris' early years with the Abwehr, it took its toll later when ill-thought-out intelligence operations marked by confusion, overlapping targets, and misinformation became more and more frequent.

Abwehr I was the espionage division and the coordinating head for espionage activity in the field. Its function was to collect information of military value to the Third Reich. It had sections that dealt specifically with naval, army, air force, and economic intelligence.(6) Abwehr II handled sabotage in enemy territory, infiltration, and subversion. Abwehr III dealt with counterespionage and security. The "Ausland" branch was the foreign liaison 
division, and it preserved contact between the oKW and the Foreign office. It evaluated information from the foreign press and kept the OKW apprised of developments in Germany's foreign policy and of the domestic and foreign affairs of other countries as far as they affected the military situation. (7) A Central Group was also formed by Canaris within the Abwehr. The "Zentralabteilung" was the administrative division which handled personnel records and finances. It also kept the agent information files and the central index of agents. (8)

All military espionage operations were the responsibility of Abwehr I. Its operative sections were broken into geographical divisions, each dealing with a particular country or area. Within the zone of German military jurisdiction--that is, Germany and its occupied territories--Abwehr I was the coordinating force behind Abwehr field offices known as "Abwehrstellen" or "Asts." (9) However, Abwehr I usually did not direct the day-to-day operations of the field units, nor did it evaluate incoming intelligence. Information was routed to the office which had requested it, or to the agency which held jurisdiction. (10)

These major intelligence centers had subposts designated "Abwehrnebenstellen," which were augmented by intelligence outposts known as "Abwehraussenstellen."(11) The field units, in conjunction with Abwehr headquarters, were responsible for all aspects of military espionage, 
including the recruitment, training, and assigning of espionage agents. Theoretically, individual agents recruited by a particular "Ast" were sent to the country or area for which the "Ast" or its subpost were responsible. For example, agents enlisted by "Abwehrstelle" Hamburg or its subpost "Nebenstelle" Bremen were, in theory, responsible for espionage against the United States.(12) The "Asts" maintained divisions corresponding to the foreign territories they operated in. But these geographic assignments were not strictly observed. Several "Abwehrstellen" might send agents to the same place, while others might not have dispatched any agents at all. These factors contributed to the inefficiency of the operation and of the organization.

In neutral countries or those allied with Germany, the Abwehr station was referred to as a "Kriegsorganisation" or KO. Generally, the KOs operated out of the individual German embassies or consulates, usually with some form of diplomatic immunity.(13) The country in which the KO was located served as a base for its various agents' operations and as a communications link for agents abroad. KO Spain, for instance, transmitted reports from its agents in Great Britain and Washington, D.C. to Abwehr headquarters in Germany • (14)

As in the case of the "Asts," espionage activity in an area monitored by a specific KO was sometimes jeopardized because of duplication and the lack of a centralized policy. 
Because of this confusion, apparently inherent in the overall Abwehr organization, work of the KOs often suffered. KOs did not have exclusive responsibility for espionage activity in their individual territory, thus interference between agents from different "Asts" or KOs was frequent. (15) Lack of communication and mismanagement of Abwehr operations and personnel caused overlapping of target choices and duplication of collected information.

The structure of both the "Asts" and the kOs corresponded to that of Abwehr headquarters; each had sections for espionage, sabotage, and counterespionage, as well as for the various geographical and technical subdivisions. The existence and survival of the "Abwehrstellen" and kOs was largely dependent upon Germany's political and military success. Military gains or losses meant the addition or loss of an "Ast" or its subpost. Neutral countries and German allies were more tolerant of the kOs as long as Germany remained a major power to be feared. Indeed, it seemed the major criticism of the KOs came from members of the German Foreign Missions, who complained over the large number of Abwehr personnel with diplomatic passports who worked out of the consulates and jeopardized work of the genuine diplomats. Kos were not required to inform the consulates of incoming Abwehr personnel, their local formation, or operations and information gathered.(16) However, when the war began to go badly for Germany, the Allied victories encouraged those 
neutral countries with German diplomatic missions to expel Abwehr personnel working under diplomatic immunity.

The agent network was under the direction of Abwehr I, which dispatched agents on intelligence missions through its "Asts" or KOs. The agents were divided into categories designated by letters which signified their position in the Abwehr. An agent employed in peacetime was known as an "Friedensagent" or F-agent. Generally, F-agents watched over military movements and the defense capabilities of the country in which they were stationed, and also gathered technical, political, economic, and scientific information not readily available to Germany. "Spannungsagenten" or s-agents were those who worked in times of international crisis or political tension. They watched for an increase of military movement. Wartime agents, "Kriegsagenten," designated as A-agents, worked behind enemy lines during actual hostilities. A "Reiseagent" was an Abwehr scout or mobile informant, and was designated as an R-agent. (17) Others were known as "V-Männer" or "Vertrauensmänner", confidence men or trusted persons.

A second category of agents, not directly employed by the Abwehr, operated under code-names. "Tramp," "Crown," and "Sex" are examples of code-names used by German agents in the United States. Code-name agents worked through either a "V-Mann" or a KO, and submitted their intelligence reports directly to these contacts. Sometimes they were employed, through their supervisor, as wireless operators 
for groups of agents in foreign countries. (18)

"Hintermänner" or "Unter-V-Männer" served as subagents and contact persons. The Abwehr had no direct dealings with these individuals, as they acted only as informers or couriers for certain Abwehr agents, sometimes unaware that they served as information sources for spies. (19)

Agent recruitment and information resources for the Abwehr were greatly varied. In Germany, many organizations and individuals were enlisted, often with mixed results, since the division of responsibility between the government, party, and private organizations was frequently vague. The Abwehr utilized any means available in its effort to aid Germany in the intelligence contest. Military and naval personnel, diplomatic missions, trade delegations, and scientific institutes, which shared industry secrets, were a part of the Abwehr's network. Additionally, organizations such as the "Deutsches Ausland-Institut," which connected German emigrants and those of German heritage with the Fatherland, and the Nazi party's "Auslandsorganisation" for party members abroad, were also used, sometimes without the knowledge of these organizations. In addition, there were free-lance agents who operated independently and offered themselves to the Abwehr in the hopes of selling whatever they could obtain. There were also those whom Abwehr personnel approached and convinced through coercion, blackmail, or patriotism to act as spies. The United States was an unwitting host to many of 
these individuals. Some were actively involved as Abwehr agents; others knowingly acted as intelligence sources. A third group innocently provided information to the Abwehr, often through institutions without apparent espionage ties. Although America attempted to maintain itself apart from the rest of the world's preoccupation with Hitler and National Socialism, its protective shell was cracked early in 1938 with the arrest of a man accused of passing information to the Germans. His apprehension resulted in the first Nazi spy trial in the United States. This first arrest, and others that followed soon after, awakened Americans to their vulnerability to forces abroad. The gravity of National Socialism in Europe and German espionage in America became more than a subject for discussion and unsubstantiated fears; it acquired sudden tangibility and a frightening reality. Germany had embarked on an aggressive espionage program; its threats were genuine. Americans found themselves vulnerable and subject to doubts concerning their country's defense. It seemed that rather abruptly the United States had been drawn into Nazi Germany's ever-widening circle of interest, as a military target for its intelligence agents. 
1. David Kahn, Hitler's Spies (New York, 1978),

2. Stanley E. Hilton, Hitler's Secret War in South America (Baton Rouge, Louisiana, 1981), 16; Kahn, Hitler's Spies, 238 .

3. Karl Abshagen, Canaris, trans. Alan Broderick (London, 1956), 93.

4. Ibid., 95; Heinz Höhne, Canaris, trans. J. Maxwell Brownjohn (New York, 1979), 197.

5. Höhne, Canaris, 196.

6. United States Navy Department, Office of Naval Intelligence, Espionage-Sabotage-Conspiracy: German and Russian Operations 1940 to 1945 (Washington, D.C., 1947), Appendix III/I; National Archives and Records Service, Guides To German Records Microfilmed at Alexandria, Virginia., No. 80. Records of the German Armed Forces High Command, Part VI, Amt Ausland/Abwehr (Washington, D.C., 1982), xv; Hilton, Hitler's Secret War, 17.

7. Kahn, Hitler's Spies, 47; National Archives and Records Service, No. $80, \mathrm{x}$.

8. Höhne, Canaris, 303.

9. United States Navy Department, Office of Naval Intelligence, Op 32-E, German Naval Intelligence (Washington, D.C., 1946), 10.

10. U.S. Navy, Espionage-Sabotage-Conspiracy, 9.

11. U.S. Navy, German Naval Intelligence, 10.

12. "German Espionage and Sabotage Against the United States," ONI Review, I.3:34 (January, 1946).

13. Ibid., 33.

14. U.S. Navy, German Naval Intelligence, 41 . 
15. Kahn, Hitler's Spies, 243.

16. Memo from the German Foreign Ministry to the German Missions, February 13, 1942, German Foreign Ministry Archives, Serial 707, frames 264235-264239; National Archives Microfilm Publication T-120, roll 357.

17. Höhne, Canaris, 199-200, 662-671.

18. U.S. Navy, German Naval Intelligence, 10, 42-43.

19. Ibid., 43; Ladislas Farago, The Game of Foxes (New York, 1971), 382. 
After 1918, the United States retreated from its involvement with other nations and returned to its national policy of isolationism. Although America had been a latecomer to the war, its money, supplies, and manpower were decisive factors in the Allied victory. The United States emerged a world power, and a nation to which much of the world owed a large financial debt. However, many Americans were disillusioned, saddled as they were with inflation, influenza, and war debts their former allies were very vocal about not wanting to repay. Having fought to "save democracy" in the "war to end all wars," Americans were left with a world that was neither entirely democratic nor without conflict. Americans, bitter over what was seen as a senseless war and disgusted with their Allies' postwar attitudes, reacted by turning their backs on Europe and European problems.

But isolationism in America turned into an illness. The symptoms were clear: fearing the country would be beseiged by hordes of people escaping the aftermath of war, Congress passed the restrictionist immigration laws of 1921 and 1924, which greatly reduced the number of immigrants 
allowed into the United States. America refused to adhere to the Treaty of Versailles, preferring to make separate peace treaties with Germany and its allies, primarily to avoid joining the League of Nations. The League was seen as a mechanism which would force Americans to deal with Europe's problems and fight European battles. The "Red Scare" of 1919-1920 and the raids against Communists and subversives in the United States were connected by some Americans to the 1917 Russian Revolution and to fears of spreading Communism. But this witchhunt for Communists was rooted in America's growing intolerance of foreigners and "radicals."

While the United States rated itself a world power following World war I, it shunned world leadership and participation in world affairs in a tragically short-sighted way. America had cooperated in war but refused to commit itself to postwar efforts to insure peace. National isolationism was strengthened throughout the $1920^{\prime} \mathrm{s}$ by these postwar attitudes. American's greatest desire was to forget the great crusade of the World war and the problems in Europe, and return to the less complicated prewar days of peace and comfort. Warren G. Harding called this a return to "normalcy." For many others, this era of conservatism, intolerance, and isolationism was remembered fondly as the prosperous days of the "Roaring Twenties."

The advent of the Great Depression in late 1929 accentuated America's fear of foreigners and foreign 
entanglements and contributed to its restrictionism and isolationism, as did the increased militarism in Europe and Japan. In his first inaugural address, Franklin D. Roosevelt likened the Depression to a foreign invader, and demanded "...broad Executive power to wage a war against the emergency...."(1) Cognizant of its domestic problems above all else, the United States attempted to close ranks. The Depression fostered a mood of national despair and confusion, marked by disappointment and disillusionment with the state of world affairs. Americans wanted only to stay out of foreign wars, and at first saw no danger to themselves from the belligerents across the Atlantic and the Pacific. Congress accepted the isolationist mood of the country and, beginning in 1935, enacted a series of Neutrality laws to keep the nation from becoming involved in any war "over there."

However, public opinion in America was increasingly offended by the domestic policies of the Nazis, which were dominated by intense anti-Semitism. In addition, Germany's growing cooperation with Italy and Japan--indicated by mutual adherence to the Anti-Comintern Pact and the Tripartite Pact--alarmed many Americans, who feared an international conspiracy against democracy. Of the three nations that threatened world peace and security, Nazi Germany was the most violent in its hatreds and the most powerful in the resources and technology of modern war. Consequently, it seemed the most dangerous to the United 
States.

Aggressive rhetoric emerging from Germany seemed to confirm this view, as did the growth of fascist-related organizations in the United States. The Friends of the New Germany preceded the German-American Bund, whose members openly wore a Nazi style uniform complete with swastika emblems. William Pelley's Silver Shirts, even Father Charles Coughlin's Social Justice Movement, and the revivified Ku Klux Klan, which sported an ideological alliance with the Bund, were the purveyors of a strain of violently abusive propaganda that at once vilified the "enemies" of the new Germany and lauded the National Socialist state.(2) This type of endorsement of the Third Reich generated fear in the minds of some Americans about the importation of National Socialist ideals and of Nazi subversion in America thought to be financed from Germany. Feelings against Germany were strong as early as June of 1935, when the German ambassador to the United States reported to Berlin that anti-German propaganda had increased and that America had become "one of the main centers of anti-German agitation." (3)

News of the capture of the first German spies since World War I broke across the United States in February, 1938, in a wave of publicity. The reputed size and range of the Nazi espionage ring in America shocked many. Even more startling was the discovery of the apparent ease with which these agents had operated, the majority without any 
professional training.

Guenther Gustav Rumrich brought about the unmasking of this particular group. A naturalized American of German birth, an unmitigated failure in civilian life, and a deserter from the United States army, Rumrich found his niche after reading the memoirs of Colonel Walter Nicolai, who had headed German military intelligence during World war I. (4) In January, 1936, Rumrich wrote to Nicolai in care of the Nazi Party newspaper, the Volkischer Beobachter. He volunteered himself as a spy for Germany, stating that if the Germans could use his services, they should insert an advertisement in the New York Times addressed to "Theodor Koerner."(5) Nicolai forwarded the letter to the head of Abwehr I, Colonel Hans Piekenbrock, who in turn gave it to the Hamburg branch which acted on Rumrich's proposal. On April 6, 1936, the New York Times contained an advertisement which read: "Theodor Koerner-Letter received, please send reply and address to Sanders, Hamburg 1, Postbox 629, Germany." (6)

Rumrich was enlisted as a spy and worked under the direction of Dr. Erich Pfeiffer of the Hamburg branch of the Abwehr. Rumrich's small group had the cover name of "Crown" and operated in conjunction with a larger ring codenamed "Ilberg."(7) "Crown" operated for approximately twenty months, during which time Rumrich was able to gather various bits of information, such as the number of cases of VD in the United States Army and the signal code the army used in 
ship-to-shore communications. He sent the information back to Pfeiffer by way of Karl Schlueter, Abwehr courier and a steward on the German ocean liner "Europa."(8)

Much of the mail sent to Germany by the spy ring in the United States first went to a mail drop in scotland, where the letters were routed on to the Abwehr. (9) The mailman delivering to the drop, a beauty parlor in Dundee owned by a woman named Jessie Jordan, noticed the large quantity of foreign mail and reported it to British counterintelligence. Since many of the suspicious letters were sent from New York, the British notified the FBI, which found upon reading the mail, evidence of the "Crown" operation in New York.(10)

At the same time, Rumrich had been asked by Pfeiffer to get a number of blank American passports for Nazi agents abroad, and had been promised $\$ 1000$ for the delivery. Unfortunately, Rumrich did not understand the difference between blank passports and passport blanks, the latter merely the form used when applying for a passport. Pretending to be "Edward Weston, Undersecretary of State," Rumrich called the New York branch of the passport division and demanded that 50 passport blanks be sent to him at his hote1.(11)

Because the request was so contrary to procedure, because no one knew an Under Secretary of State named Edward Weston, and because passport blanks were available to anyone who wanted them, the clerks notified Federal authorities, 
who prepared a fake package for "Mr. Weston." What followed next was a comedy of hide-and-seek, with Rumrich rerouting the package by telephone and the Alien Squad of the New York police department tailing after. Rumrich was finally arrested on February 15, 1938, and was turned over to the FBI where he faced evidence the FBI had amassed concerning activities of the "Crown" ring. (12)

Rumrich not only confessed to his own position in the "Crown" ring, but turned state's evidence and implicated others, including those agents he knew who were involved in "Ilberg." The ramifications of Rumrich's arrest and confession were significant in that he exposed the activities of agents who had since left the country. "Ilberg" and its predecessor "Sex" had had long and successful operating careers prior to the confession of Rumrich, dating back to 1927, when the first agent of "Sex" entered the United States. (13)

"Sex" was an abbreviation of an alias, "William Sexton," one of many used by William Lonkowski. Lonkowski joined the Abwehr shortly after the first World War. Because of his background in aviation he was sent to the United States in the late twenties to gather intelligence for the German airforce, which was forming secretly. Lonkowski and two co-agents worked in the American air industry under this operative code name.(14) In the late twenties and early thirties Lonkowski and his two confederates, Werner Georg Gudenberg and Otto Voss, were 
able to send the Abwehr aircraft secrets copied and stolen from the various plants where they had worked. These included the Curtiss Aircraft plant in New York, which at the time, was producing equipment for the government.

In 1934, Lonkowski merged his ring with that of Dr. Ignatz Griebl, who used the codename "Ilberg." Griebl had come to the United States after World War I, where he set up a physician's practice in New York and became an American citizen. Like Guenther Rumrich, Griebl volunteered his services as an espionage agent through a letter, in this case to the Nazi Propaganda Minister, Joseph Goebbels. (15) In order to recruit suitable individuals to help him, Griebl involved himself in the Friends of the New Germany, the organization which preceded the German-American Bund, through which William Lonkowski heard of Griebl's activities. The two joined forces, using Lonkowski's friends and the courier system developed by Griebl, which utilized the German ocean liners of the Hamburg-American and North German Lloyd lines and selected crew members as a transmission service to and from Germany.(16) In addition, they acquired contacts at American defense installations and manufacturing plants, and over an extended period of time, were successful in obtaining military information for the Abwehr. Their intelligence coups included: obtaining specifications from the Sikorsky plant at Farmingdale, Long Island, of pursuit planes reputed to be the fastest in the world; plans for a navy scout bomber being built by Vought 
Aviation; bombers being developed by Boeing and Douglas; blueprints of three destroyers; drawings for a new anti-aircraft gun and for an experimental army plane for night bombing; and classified U.S. Army maps.(17) All information was sent by way of courier to pfeiffer in Germany.

It was on one of his deliveries to the courier on board the "Europa" in September, 1935, that Lonkowski was stopped and searched by U.S. customs guards. His pockets and the violin case he was carrying were found to contain documents, drawings of planes, and film negatives which detailed an airplane that turned out to be a new Curtiss light bomber.(18) Lonkowski was questioned and, oddly enough, released with instructions to return the next morning for further interrogation. With Griebl's help, Lonkowski escaped across the Canadian border and from there boarded a German freighter that returned him to Germany. Why Lonkowski was allowed to leave remains unclear, unless the importance of the documents and films he was concealing was not immediately recognized, though American intelligence personnel had been called in to examine the material. What is certain is that American officials exhibited a high degree of naivete in this incident. Aside from his name and the information he was carrying, Lonkowski yielded nothing in questioning. In fact his position, the success of "Operation sex," and his escape were never fully revealed or understood until Guenther Rumrich became the key 
witness for the Federal prosecution in the spy trial of October, 1938. "Operation Sex," renamed "Operation Ilberg," had been able to operate for almost three more years without interruption from American authorities.

In June, 1938, following Rumrich's arrest and the grand jury hearings, eighteen individuals were charged by Federal indictment with having conspired to violate American espionage laws. The Federal authorities took the almost unprecedented step of naming all those indicted as agents of the German government. The New York Times reported on June 21:

...Germany was officially named as the party responsible for the under-cover force that aggressively sought to pry out the best technical military defense secrets of the United States. (19)

However, only four faced trial on October 14, 1938, and were subsequently convicted. Otto Voss, Lonkowski's aide who worked at the Sikorsky aircraft plant, received a six year sentence, and Johanna Hofmann, who had worked as a hairdresser and courier on the "Europa," got four years. For his theft of the Army's ship-to-shore communications code, Erich Glaser, a private in the Eighteenth Reconnaissance Squadron stationed at Mitchell Field, Long Island, received a two year sentence. Gustav Rumrich pleaded guilty to the indictment of espionage and was also sentenced to two years. (20)

The others named in the Federal indictment had either escaped the United States or had never left Germany. Karl 
Schlueter was exposed as a courier, but escaped arrest. Dr. Ignatz Griebl and Werner Gudenberg had been recruited by the FBI as witnesses following Rumrich's arrest, and both testified for the Federal Grand Jury in May, 1938, before the indictments were handed down in June. Though Rumrich's earliest admissions had identified them as part of the Nazi espionage ring, they seemed willing enough to testify and were neither bonded nor guarded by the FBI. They eluded trial by returning to Germany on the ships which had served the couriers, supposedly with neither ticket nor passport.(21) An attempt to arrest Griebl when the "Bremen" made its first stop in France was foiled by the Captain who refused to give up Griebl to the French police. (22) Erich Pfeiffer, who directed the spies in America for the Abwehr, was indicted "in absentia."(23)

1938 proved to be a landmark year in terms of German-American relations: it marked the beginning of a steady erosion of isolationist convictions within the United States and culminated in the recall of the German and American ambassadors from their respective posts. Guenther Rumrich's arrest in February, the federal indictments of eighteen Nazi spies in June, and the spy trial in October were seen by Americans in light of a series of Nazi-initiated European crises. These included the annexation of Austria in March, the threat to Czechoslovakia in the summer of 1938, and the attacks on Jewish life and property during the "Kristallnacht" pogrom in November. 
These events all served to increase American anxiety and hostility toward Germany's aggressive internal and external policies.

Relations between the two countries deteriorated to such an extent in 1938 that German Ambassador Dieckhoff wrote in November to the Foreign Ministry of a "...storm of anti-German feeling sweeping America."(24) Similarly, before his recall, American Ambassador Hugh Wilson described the Nazi-backed attacks on Jews in Germany, and stated, "...these pogroms dispel any hope of moderation in German-American relations." (25)

German diplomats in the United States were under no illusions that Germany could count on America's isolationist sentiment in all circumstances; indeed, the events of 1938 led many Americans to view world developments as an ideological struggle between democracy and dictatorship--a conflict between good and evil. In the minds of some Americans, the Nazis became the subverters of peace, truth, and virtue. The discovery of Nazi spies in America was seen as a personal attack on the nation and a conspiracy designed to undermine the allegiance of naturalized German-Americans.

The Rumrich trial alerted the United States government and the American public to the gravity of the German espionage problem. The three male defendants in the Rumrich trial were naturalized American citizens, as were other important members of the spy ring, including Griebl and Gudenberg. That these individuals had taken an oath of 
allegiance to the United States and had forsworn loyalty to the country of their birth made their crimes all the more treacherous. Their betrayal seemed to give credence to the fear that German-Americans were being manipulated by the Third Reich, and that the international community of people of German blood were part of Hitler's German "Volk," with all of the obligations the term implied. Though the average American was more than a little confused about the accomplishments and potential of German espionage in the United States as revealed by the media during the Rumrich trial, most were profoundly affected by the fact that German-born American citizens had chosen to spy upon their adopted country

The spy trial of 1938 and the activities of pro-Nazi groups such as the German-American Bund, which emphasized its connection to the Third Reich, ran afoul of American sensitivity toward organizations and individuals within the United States that maintained ties to another country. The trial also contributed to the public's reaction against National Socialism and reinforced popular suspicion of foreigners. This was partly because the information Americans acquired concerning German espionage in the United States was learned through media publicity--books, magazines, and newspapers--some of which tended to exaggerate and sensationalize the danger.(26)

Magazine articles that wrote of "Expanding Espionage" and "Spy Scares" and asked, "Is America Infested With Nazi 
Spies?" could not help but influence their reading public as to the magnitude of German spying in America. (27) Books such as Sabotage: How to Guard Against It, Armies of Spies, Secret Agents Against America, Total Espionage, and The Brown Network, all published in the United States before Pearl Harbor, at times used embellishment and allegation to capitalize on what was already known about America as a target for German espionage agents. (28) Americans were told that:

Before the United States started paying attention to foreign agents, there were fifty thousand individuals in this country who...contributed to the stream of information whose end was in the Nazi espionage centers in Berlin and Hamburg. (29)

It was also stated that the German diplomatic corps had been organized into a fifth column unit staffed by "...Nazi saboteur-diplomats..." who began arriving in the United States in 1933 and subsequently "...entangled the forty-eight states in a web of secret destruction."(30)

Many of these public sources attributed the growth of the Nazi spy system in the United States to the racial doctrine of the Hitler government which claimed:

...every 'Aryan' born German abroad remains a German regardless of whether he has sworn allegiance to a foreign government or not. Germans abroad must be at the disposal of the Reich and are obliged to serve its interests. (31)

Thus the foreign born, irrespective of citizenship, were labeled "aliens," and described as:

...individuals of an aggressively foreign character, wholly dissimilar from and unsympathetic to the standards and political system that prevail 
in the United States. A different

allegiance--regardless of length of American

residence--psychological estrangement and downright hostility are the characteristics of those who are the alien agitators, conspirators and spies....(32)

Nativism and distrust of foreigners was not new in the United States. But these attitudes toward Germans and German-Americans were strengthened in 1938 by Germany's actions abroad and the Rumrich trial, and because of associated published information Americans were reading and what they came to believe about the threat of German spies.

Fears about Nazi espionage agents, and the increasingly strong conviction that a vast Nazi fifth column movement operated in the United States, led to restrictions on immigrants from Germany and those refugees escaping National Socialism. Assuming that the Nazis only allowed selected individuals to emigrate, many Americans, including a number of state Department officials, felt that refugees from Germany were part of a German fifth column movement sent to threaten the security of the United States. (33) Assistant Secretary of State Breckenridge Long, who was in charge of the State Department's Visa section, and a number of his subordinates believed there was a subversive element among applicants for visas to America, and that many refugees were fifth columnists in disguise. (34) Long wrote in his diary:

It is very apparent that the Germans are using visitor's visas to send agents and documents through the United States and are using their Consulates in the United States as headquarters for their nationals who enter on transit permits and who are 
carrying confidential documents...(35)

The suspicion that spies were entering the United States in the guise of refugees actually had very little basis in fact. The nation's immigration quota system and the State Department's visa regulations were very tight. Many of the American Consuls abroad whose responsibility it was to issue visas felt it was also their responsibility to keep the number issued down to a minimum.(36) Ultimately each "alien" was required to have two American sponsors, and the sponsors were asked to submit loyalty or moral affidavits. (37) These actions were partially attributable to the Rumrich trial and the developing fear of German espionage in America.

Because German agents had indeed been arrested, there was some obvious basis of fact for the fears the nation harbored concerning naturalized German-Americans and a fifth column in the United States sponsored by the Third Reich. But German espionage was not as widespread as people seemed ready to believe, nor was the united states the veritable "paradise for spies" as was claimed in Total Espionage by Curt Riess, a popular book of the period. (38) Nevertheless, following the 1938 arrest and indictment of German spies, there was a demand for stronger and more adequate anti-espionage defenses in the United States.

What passed for counterespionage action in the United States had so far proven more of a liability than an asset by the Rumrich case. Certainly the FBI had done little to 
validate J. Edgar Hoover's claim that his men had "smashed" the greatest German spy ring since the First World War; many of the important members had escaped and others in America and Germany remained untouched. (39)

This ineffective counter-spying was excused by the implication that America's innate purity had kept it from the tradition of warfare that required counterespionage tactics:

Through many of our wars and most of the prospering intervals of peace one might have hidden all available American counter-spies behind a telegraph pole. And this absolute lack has appeared to be a special blessing, conferred on America by the temperament of the nation.... (40)

It was claimed that, prior to the threats on democracy from Germany, Japan, and Italy, America had had no need of an espionage or counterespionage system because:

The United States was not imperialistic; it had no desire to make conquests and therefore was not military. As for industrial espionage--America had no need of it. No spy could learn from another country anything that America did not already know. American industry was further developed than the industry of any other country. (41)

When sentencing the four convicted German spies in late November, 1938, the presiding judge publicly chided the FBI for its carelessness and ineptitude in letting members of the spy ring escape.(42) Shortly after the trial, President Roosevelt announced that the need for a stronger espionage force was to be served through the coordinated forces of the FBI and army and navy intelligence. (43) America's counterespionage facilities were to be improved 
and expanded in order to combat the intelligence threat to the nation posed by Nazi Germany.

1938 was a shocking year that portended things to come. Hitler's Third Reich was beginning to alter the face of Europe, and in America there was a gradual change in the isolationist conviction that the United States could live as an island unto itself. The Rumrich trial and the publisity that followed awakened the country to its vulnerability to enemy agents, and steps were taken to tighten security. However, what the FBI had uncovered with the aid of Rumrich's testimony did not disturb the core of Abwehr agents in the United States. These agents were able to operate, apparently unimpeded, for almost three more years. 
1. Inaugural Addresses of the Presidents of the United States From George Washington 1789 to Richard Milhous Nixon 1973 (Washington, D.C., 1974), 238 .

2. J.C. Carlson, Undercover (New York, 1943), $56-57,151-153$.

3. Documents on German Foreign Policy (Washington, D.C., 1949-1983), Series C, Volume IV, 316.

4. Richard Rowan, Secret Agents Against America (New York, 1939), 108; Farago, Game of Foxes, 69, 71; Curt Reiss, Total Espionage (New York, 1941), 250.

5. Michael Sayers and Albert Kahn, Sabotage! The Secret War Against America (New York, 1942), 15; Farago, Game of Foxes, 70 .

6. New York Times (April 6, 1936), 3, column 1 .

7. Farago, Game of Foxes, 42 .

8. Ibid., 72-73; Rowan, Secret Agents, 122.

9. Will Irwin, What You Should know About Spies and Saboteurs (New York, 1943), 90; New York Times (June 21, 1938), 12: 7 .

10. Farago, Game of Foxes, 75-76.

11. Kahn, Hitler's Spies, 328 .

12. Rowan, Secret Agents, 125-126.

13. Farago, Game of Foxes, 20.

14. Ibid., 21, 23-24.

15. Kahn, Hitler's Spies, 327; New York Times (October 18, 1938), 28:6.

16. Reiss, Total Espionage, 48; Rowan, Secret Agents, 135 .

17. Farago, Game of Foxes, 36-37; Kahn, Hitler's Spies, 328; New York Times (June 21, 1938), 1:8. 
18. Farago, Game of Foxes, 37; Rowan, Secret Agents, 130; Reiss, Total Espionage, 48-49.

19. New York Times (June 21, 1938), 1:8.

20. Sayers and Kahn, Sabotage, 16.

21. Irwin, what You Should Know, 93; Rowan, Secret Agents, 133-134.

22. Irwin, What You Should Know, 94.

23. Farago, Game of Foxes, 82.

24. Documents on German Foreign Policy D: IV:639.

25. United States State Department, Foreign Relations of the United States: Diplomatic Papers (washington, D.C., 1955-1969), 1938: I I:395.

26. Hans L. Trefousse, "The Failure of German Intelligence in the United States, 1935-1945," Mississippi Valley Historical Review, XLII.1:86 (June, 1955).

27. "Expanding Espionage," Literary Digest, CXXI.22:13-14 (May 30, 1936); "Spy Scare," Literary Digest, CXXII.4:5 (July 25, 1936); "Is American Infested With Nazi Spies?" Christian Century, LV.44:3 (November 2, 1938).

28. See: Harry Farren, Sabotage: How To Guard Against It (New York, 1940); Joseph Gollomb, Armies of Spies (New York, 1939); Richard Rowan, Secret Agents Against America (New York, 1938); Curt Reiss, Total Espionage (New York, 1941); World Committee for the Victims of German Fascism, The Brown Network (New York, 1936).

29. Reiss, Total Espionage, 122.

30. Sayers and Kahn, Sabotage, 11-12; Irwin, What You Should know, 85.

31. Rowan, Secret Agents, 16.

32. Ibid., 10 .

33. David S. Wyman, Paper Walls (Amherst, Massachusetts, 1968), 174, 175, 182, 186 .

34. Saul Friedman, No Haven For the Oppressed (Detroit, Michigan, 1973), 119. 
35. Fred L. Israel, ed., The War Diary of Breckenridge Long (Lincoln, Nebraska, 1966), 114 .

36. Arthur D. Morse, While Six Million Died (New York, 1967), 197.

37. Ibid., 301; Wyman, Paper Walls, 192.

38. Reiss, Total Espionage, 46.

39. Rowan, Secret Agents, 128.

40. Ibid., 4 .

41. Reiss, Total Espionage, 45.

42. Rowan, Secret Agents, 147-148.

42. Ibid., 149-151. 
CHAPTER IV

\section{ANATOMY OF A SPY NETWORK}

In February, 1939, William G. Sebold, a naturalized American of German birth, returned to Germany to visit his family. Sebold had left Germany after world War I, having served in the Kaiser's army. In the United States, he worked in various industrial and airplane plants throughout the country. On disembarking his ship in Hamburg, Sebold listed his occupation on the landing card as a mechanic with the Consolidated Aircraft Company plant in San Diego, California. This information appealed to the Gestapo and Sebold was invited to their Düsseldorf office.(1)

When Sebold declined, the Gestapo officials revealed that they knew of Sebold's past criminal record. In his youth, Sebold had spent time in German jails for smuggling and other offenses. Apparently sebold had not revealed these criminal activities to the American authorities when applying for citizenship. Threatened with reprisals against his family, a concentration camp stay, divulgence of his past sins, and perhaps the revocation of his American citizenship, Sebold went to the Gestapo office where he accepted an offer to work as a German spy.(2)

Sebold's case was forwarded by the Gestapo to the "Abwehrstelle" in Hamburg, which was in charge of espionage 
against the United States. The head of the air intelligence sector at Hamburg, Major Nikolaus Ritter, was told by the Gestapo that Sebold had "volunteered" to act as a spy and had been thoroughly checked out. The Gestapo recommended he be hired by the Abwehr for work in America.(3) It was the policy of the Abwehr, as ordered by Admiral Canaris, not to use pressure, threats, or blackmail in the recruitment of agents. The principle of such action was not questioned as much as it simply was bad for public relations and would limit enlistment. The fact that the Abwehr took William Sebold on as an agent shows how little the Reich agencies communicated with one another. The Gestapo's methods were not those of the Abwehr, yet it was almost taken for granted by Ritter that Sebold had volunteered, as the Gestapo maintained, and that he would work diligently for Germany despite his American citizenship.

It was arranged for sebold to attend the spy school in Hamburg where he was trained in the use of a Leica camera and shown how to make microphotographic reductions of documents. He was taught how to use secret inks, Morse telegraphy, codes, and the shortwave radio.(4) Ritter preferred using American citizens as radio operators; thus Sebold's job in the United States would be to radio intelligence gathered by other agents back to Germany, or make microphotographs of documents for mailing to the Abwehr .

Prior to his return to the United States, 
Sebold--codename "Tramp"--was supplied with a forged American passport made out to "william Sawyer", $\$ 1000$ in American currency, and a list of four agents in New York whose reports he was to forward to Germany. They were: Frederick Joubert Duquesne, Lilly Stein, Everett Roeder, and Hermann Lang. (5) sebold met with each after his return to America in early February, 1940.

Under instructions from his Abwehr contact, Major Ritter, Sebold set up a front for his operations called the "Diesel Research Company," and in a house on Long Island, installed a shortwave radio with which he contacted Hamburg with messages from agents.(6) All communications were to be sent in code, the key being a popular novel of the period, All This and Heaven Too by Rachel Field. (7)

Sebold was an extremely conscientious radio operator, and maintained almost daily communication with the Abwehr in Germany. Using the call letters CQDXVW-2, he sent out prompt weather reports and was always up to date on ship movements in and out of New York harbor. (8) However, the primary importance of sebold and his radio lay in the speed with which important information could be transmitted from America to Germany. Vital communications concerning ships, their destinations and cargoes tolerated no delay, particularly if the German U-boats wanted to plot intercept coordinates. All urgent messages from agents were transmitted by radio, while less important or longer reports went via courier. Consequently, it was necessary to have a 
trained and reliable radio operator who could get the intelligence out, and William Sebold was eminently qualified. In fact, his station functioned so dependably that Major Ritter expanded the group for which Sebold transmitted. Agents who operated under other Abwehr officers were allowed to use sebold as their communications channel.(9) As a result, Sebold became acquainted with a number of German agents working in the New York area. As did Sebold, many of them worked with the Duquesne ring, while others operated independently or in conjunction with other groups.

The importance of William Sebold cannot be stressed enough, because unfortunately for the Abwehr, Sebold was the key figure that brought down one of its largest spy rings operating in America. While sebold was visiting his family in Mulheim, and being pressured by the Gestapo in Düsseldorf, he visited the American Consulate in Cologne, ostensibly to send some money to a family member in the United States.(10) There he confided to consular officials the attempt on the part of the Germans to blackmail him into becoming a spy for the Abwehr and his wish to cooperate with the American authorities in order to expose the German spy organization in the United States.(11) Thus Sebold appeared to go along enthusiastically with the Abwehr's plans for him in America, and did well at the Abwehr's spy school in Hamburg •

When Sebold returned to the United States early in 
1940, State Department officials notified the FBI of the deception, and from that time on sebold worked with the FBI. Between January, 1940, and June, 1941, when arrests were made, all contacts between sebold and his co-agents that took place in Sebold's Diesel Research office were recorded and filmed through one-way mirrors by the FBI. Sebold's radio station on Long Island was manned by a Federal agent and all messages sent to the Abwehr were either screened for dangerous information, or were sent intact and the plans or facts behind the intelligence changed.(12) For nearly eighteen months William sebold served as the communications link for almost all of the American-based agents of the Hamburg branch of the Abwehr, as well as for an assortment of other agents from various branches and kOs, all of whom were monitored by the FBI.

Frederick Joubert Duquesne was the accepted leader of the group of German spies in America organized by the Abwehr's Major Ritter. A native of Cape Colony, South Africa, and a naturalized American, Duquesne was in his sixties when Sebold first met him, but still played an active role in the espionage activities of his New York ring.

Duquesne had worked for German intelligence to sabotage British shipping during the First world War. He was arrested in New York in 1918 and an attempt to extradite him was made by the British, who charged him with murder in connection with the sinking of the British steamship 
"Tennyson."(13) However, Duquesne escaped authorities until 1932, and by then Britain was no longer interested in extradition on the old murder charge. In October, 1937, when Major Nikolaus Ritter arrived in the United States to oversee the formation of a new spy group, he contacted Duquesne who had remained on the Abwehr's "sleeper" list as a prospective agent, and enlisted him to work actively for the Abwehr.

Duquesne's ability to supply information endeared him to his Abwehr masters, who were often amazed at his skill. However, his aptitude in procurement involved no real mystery. Security and censorship were not always rigidly enforced in the United States, and evidently Duquesne was sufficiently talented to avoid incurring suspicion when he attended Army maneuvers or visited ships in New York Harbor, camera or notepad in hand. In addition, Duquesne used a variety of information contacts, who provided him with scraps of intelligence which he forwarded to Germany for insertion into the larger espionage puzzle.

When other means failed, Duquesne often obtained his intelligence through letter writing. He was able to obtain a great deal of knowledge about American industrial products and manufacturing conditions through written communications in which he described himself as a student of the industry, or as a wholesaler.(14) For example, to acquire information on a new gas mask the Army's Chemical Warfare Service was developing, Duquesne wrote a letter to the head of the 
Service, identifying himself as a "well-known, responsible, and reputable writer and lecturer," as well as a "good citizen," and received what he had asked for through the mail.(15) Duquesne claimed to have obtained photographs of a new Navy speedboat by writing to the Navy Department in Washington. (16)

The intelligence Duquesne acquired included: information on a new Garand rifle; tanks and anti-tank weapons; the specifications of a new bomb he claimed the DuPont plant in Delaware had developed; various drawings and designs; reports on the nature and extent of equipment being sent to Great Britain; and data on ship sailings. (17) It was Duquesne who reported Churchill's arrival in the United States on the "King George V" in February, 1941, which of course was patently untrue, but impressed everyone back in Germany nevertheless since the ship had been in Annapolis in January.(18) Whether true or not, Duquesne always had something to send.

By the time William Sebold arrived in the United States to take up his guise as a radio operator for the Abwehr, Frederick Duquesne had become more interested in sabotage then in mere spying. He informed sebold (and the FBI) of his plans to blow up the General Electric plant in Schenectady, New York, and sabotage the DuPont powder works at Wilmington, Delaware. He also suggested putting a bomb in Franklin Roosevelt's church at Hyde Park. (19) In addition, Duquesne advocated burning the French liner 
"Normandie," which had been refitted as a United States Navy auxiliary ship and renamed the "Lafayette." (20)

Duquesne's proposed methods of sabotage included his own invention, the "chiclet" bomb. According to Duquesne, one chewed the gum thoroughly and then folded it around a phosphorous compound, after which it could be planted anywhere without arousing suspicion. The greatest advantage of the "chiclet" bomb was its inability to explode in temperatures under 72 degrees. (21) Temperatures above 72 degrees would trigger a chemical reaction, causing the phosphorous compound to generate intense heat, igniting whatever it was attached to. Duquesne explained that a similar incendiary device could be made with candy. For big jobs he preferred a lead-pipe bomb with dynamite caps and a slow-burning fuse. (22)

Hermann Lang, another of Sebold's contacts in America, had proved to be one of the Abwehr's greatest American spy coups, and a personal success for Major Ritter of "Abwehrstelle" Hamburg and his spy operation in the United states. Lang worked as an assembly inspector at the Norden plant, and had stolen and made copies of many of the assembly blueprints of the Norden bombsight for the Abwehr. In its quest for intelligence from the American Air Force and aircraft industry, the German espionage organization had long been interested in the bombsight developed by American inventors. Reportedly, this bombsight enabled a bombardier to determine the exact moment a bomb 
must be dropped to accurately hit a target. Different versions of this sight had been developed and, of course, the Abwehr was interested in any of them. Requests had gone out to the spy rings under Rumrich and Griebl in 1937, but none of the members had access to information concerning the bombsight. In fact, Hermann Lang sent the first sketches of the Norden bombsight to the Abwehr on his own initiative through one of the numerous letter drops employed by the Abwehr. The primary reason for sending Nikolaus Ritter to the United States was to facilitate the shipment of Lang's information back to Germany and coordinate an espionage ring. (23)

Hermann Lang was a naturalized American citizen, born in Germany. His motives as a spy were unique, since he did not profess to be a believer in National Socialism nor did he hate the united States. He claimed no interest in monetary rewards for his work as a spy, though he did not refuse payment. He considered himself to be a good German, and his position as an assembly inspector at the Norden plant gave him access to some of the bombsight blueprints. Perhaps this and his misplaced patriotism were reasons enough for his theft of the material.

For security reasons, sections of the sight were assembled at different plants. However, when Lang knew he would have custody of certain sectional blueprints for a number of days, he took them home at night and traced the prints rather than leaving them in the safe at the plant. 
Over a period of time, Lang smuggled copies of Norden bombsight parts to Germany by way of ship courier, where they were assembled. Missing parts were constructed by Luftwaffe engineers. (24) Lang himself made a trip to Germany--courtesy of the Abwehr--to help with assembling a new and improved bombsight, based on the Norden model, developed by German experts. There he received the congratulations of Hermann Goering. (25)

Major Ritter also recruited two more "sleepers" for work with the Abwehr during his trip to the United States in 1937. Everett Roeder and Lilly Stein, along with Duquesne and Lang, became part of William Sebold's major contact circle. According to FBI sources, Roeder had been born in New York, but had evidently been approached by German authorities during a visit to Germany, in much the same manner as Sebold had been. (26) The difference between the two was that Roeder accepted the Abwehr's request to act as a spy, primarily because of the money promised for any vital information he could relay to Germany. Roeder was employed by the Sperry Gyroscope factory, which was involved in the production of the Sperry bombsight and gyroscopes. However until his activation by spymaster Ritter, Roeder was kept as a "sleeper," even during the Abwehr's crucial search for intelligence on the Norden bombsight.

Roeder's employment as an engineer and designer at the Sperry plant gave him access to a variety of confidential mechanisms being developed for the United States Army and 
Navy. His deliveries to the Abwehr included specifications of the radio instrumentation on the Glenn Martin bomber, drawings of range-finders, blind-flying instruments, a bank-and-turn indicator, and a navigator compass. (27) Roeder also derived an income from his work as an inventor of firearm-related devices, which he sometimes shared with the Abwehr. According to the FBI, Roeder was probably the Abwehr's greatest producer of detailed technical data in America. (28)

Vienna-born Lilly stein worked as a fashion model in New York City, and operated as a courier for Major Ritter. Because of her work as a model, stein developed ties to influential people in New York and Washington. Her ability to move in society brought her into contact with many highly placed individuals, and she was able to pick up information by merely listening to the conversation of insiders. (29)

In the United States, the Abwehr had other spy rings about which Sebold had varying degrees of information. Among these was the group under the leadership of Kurt Ludwig, an American of German parentage, who began his espionage career in the United States in March of 1940. Ludwig had spent most of his life in Germany, but upon reaching maturity had indicated his desire to retain his American citizenship. FBI records state that Ludwig claimed to have been involved with Adolf Hitler and the Nazis in the Munich "Putsch" of 1923, and that he knew many high officials in the Nazi party. (30) In fact, according to 
Ludwig, it was Heinrich Himmler who encouraged him to become an Abwehr agent and practice his spy craft in the United States. (31)

Ludwig received his instructions from spymaster Major Ulrich von der Osten of the Abwehr's KO in Spain. Upon arriving in the United States in 1940, Ludwig was directed to form an espionage ring and obtain information concerning the size, equipment, and location of American army, navy, and airforce bases along the Eastern seaboard, as well as information on arms production and convoy movements. Ludwig himself, usually accompanied by his secretary, Lucy Boehmler, visited nearly every Army camp and airfield on the East coast.

Often either Ludwig or his companion would draw soldiers into conversations about their camp and its equipment, where they had been before and whether they were to be relocated. A favorite way to collect information was to pick up hitchhiking soldiers in the vicinity of army camps. Apparently Ludwig sometimes tried to disarm those he was questioning with his ignorance. In one instance, after picking up two soldiers, he asked if the airplanes lined up on the field could be bought for $\$ 1200$. The soldiers responded that the particular planes sold for approximately $\$ 30,000$ each. Ludwig then asked if the planes could fly as fast as the speed of an automobile, and whether a large cement mixer on the side of the road was an anti-aircraft gun. (32) Ludwig also visited many of the docks, harbors, 
and war factories along the coast, and even toured the white House in Washington. (33)

Ludwig's group of seven was for the most part a young and inexperienced company, with the noted exception of the group's technical advisor, Paul Borchardt-Battuta, a retired officer of the German army. FBI reports indicate that prior to his coming to the United States in early 1939, Borchardt had been placed in Dachau concentration camp because of his supposed Jewish heritage. He was released after only sixteen days, and with the help of German officials obtained a non-quota visa to the United States. (34)

Borchardt had evidently been on the Abwehr's payroll for a number of years, and his stay at Dachau was an elaborate ruse designed to absolve him from suspicion in the United States. There is no doubt that Borchardt was sent to the United States specifically to secure information concerning its national defense preparations, thus marking Borchardt as one of the few about whom there is concrete evidence that he used his position as a "Jewish refugee" in order to engage in espionage against America. (35)

Despite the youth of its members, the Ludwig ring was a productive and active organization. Aside from Borchardt, Ludwig's contacts included a soldier stationed at Governor's Island in New York Harbor. Rene Froehlich supplied Ludwig with lists of the admissions and discharges from the military hospital on Governor's Island, from which Ludwig was able to determine where specific military units were 
stationed. Prior to his induction into the army, Froehlich had provided Ludwig with technical and military magazines, and in fact had established a magazine and book selling business through which he was able to procure these magazines, as well as army and navy publications at dealer's prices. (36) In his capacity as a soldier, Froehlich continued to provide Ludwig with technical publications concerning aviation and defense production, and had material from the army and navy directed to him which he turned over to Ludwig for transmission to Germany. (37) Rene Froehlich was born in Germany, but claimed American citizenship through the naturalization of his father.

Hans Pagel and Frederick Schlosser were both members of the German-American Youth Movement, an affiliate of the Bund, and through this organization became acquainted with Ludwig. The two observed the ships and cargoes at the New York City waterfront, and with Ludwig visited some of the military establishments and defense plants in the area. (38) Schlosser was born in the United States but Pagel was a German citizen.

Another member of the group, Karl Mueller, also accompanied Ludwig on trips to airports and defense plants on Long Island, and furnished him with information concerning airplane production in the United States. (39)

The sixth member, Helen Mayer, was born in Brooklyn. She sought out individuals employed in the defense industry, developed relationships with them, and pumped them for 
information about their jobs and production at their plants. Her home served as a frequent meeting place for her group and others interested in Germany's success, and she often held parties which were attended--according to one report--by "a lot of men with square-looking heads... and good Heinie names."(40) Mayer also helped Ludwig with his correspondence to Germany, and provided him with magazines and periodicals which contained information she deemed valuable to his activities. (41)

Ludwig also employed Karl Schroetter of Miami, a naturalized American and a former deputy sheriff in Louisiana and Pennsylvania. Schroetter reported to Ludwig on the defense facilities located in Florida.(42)

An important member of the ring was eighteen year old Lucy Boehmler, who acted as Ludwig's secretary. Boehmler accompanied Ludwig on his trips up and down the Atlantic seaboard checking army and navy camps. One of Lucy's most important duties as Ludwig's assistant was to keep an active card file on United States army camps, the disposition of American military forces, troop movements, and arms production. (43)

Boehmler's routine chores included frequent perusal of the newspapers of the Eastern coast of the United States, as well as the study of a number of technical journals, manuals, or book publications such as Electrical World, Iron Age, and The Aircraft Yearbook. The American press harbored a wealth of information and was a cheap and 
available source of intelligence. From selected newspaper sources, Lucy clipped articles pertaining to defense plants along the East coast, or items about soldiers home on visits to their families from camps identified in the reports. From technical publications she was generally able to glean significant details concerning production, raw materials, and shipments by railroad or steamship. (44)

Lucy also maintained detailed records on Ludwig's observations and of the intelligence gathered by the group, and helped Ludwig in preparing secret messages for transmission back to the Abwehr. The information Ludwig sent by mail to Germany through mail drops in Spain or Portugal was either in code, or written on the backs or between the lines of normal letters with a mixture of Pyramidon--a headache remedy--and water. The mixture dried clear and invisible, but could be read if treated with iodine.(45) Lucy Boehmler was born in Germany, and like Hans Pagel and Frederick Schlosser, had been active in the Bund-affiliated German-American Youth group.

The Ludwig and Duquesne groups represented the most successful period of German espionage in America, and what the Abwehr considered its highest level of producing agents in the United States. Of course, it could only benefit spymasters von der Osten, Pfeiffer, Ritter, and even Canaris to tout their operations and agents in America. The Abwehr procured intelligence; it did not evaluate the information. The Abwehr stations were supposed to dispense with blatantly 
false intelligence before sending it on to the evaluating agencies, but they rarely had the comprehensive foreknowledge to know what to disregard, as in the case of William sebold and the information he was forwarding to the Abwehr. The truth was that the structure of the Third Reich's intelligence apparatus fostered an uncontrolled competition that saw each agency that dabbled in espionage scrambling to be the first with the most. Consequently, the Abwehr felt obliged to jealously guard its position as the intelligence and counterespionage organ of the German armed forces, and to produce intelligence no matter how questionable the information or the agents who sent it, for there were other departments in the intelligence establishment of the Third Reich anxious to discredit or replace the Abwehr.

Criticism of Abwehr activities in the United States between the beginning of the war in Europe and Pearl Harbor emanated strongly from the German diplomats stationed in America, particularly from the Chargé of the German Embassy, Dr. Hans Thomsen. (46) Thomsen's boss, Foreign Secretary Joachim von Ribbentrop, resented the reputed success of the Abwehr in America and had sought to establish his own intelligence network through his diplomats and German missions abroad; however, he was forced to depend on the SD and Abwehr for the majority of his secret intelligence. (47) Ribbentrop opposed Abwehr actions in America for his own reasons, but used the ammunition supplied by Abwehr mishaps, 
such as the exposure of Guenther Gustav Rumrich and the full story behind his enlistment in the Abwehr, to enhance the prestige of his own organization. Hans Thomsen also abhorred what he saw as incompetence on the part of the Abwehr because he feared the further degeneration of German-American relations.

Germany's invasion of Poland in the fall of 1939, the invasion of Scandinavia, and the march across western Europe culminating in the fall of France in June of 1940, brought America closer to the side of Britain and further from neutrality. President Roosevelt responded in september, 1940, with an executive agreement that transferred fifty old warships no longer in active service to the British in exchange for eight air and naval bases on British possessions ranging from Newfoundland to British Guiana. Roosevelt continued assistance to Britain in 1941 with Lend-Lease, which allowed goods and defense articles to go to any nation whose defense the President considered vital to the security of the United States. Both the bases-for-destroyers deal and Lend-Lease were violations of the neutrality claimed by the United States, and were, in essence, unofficial declarations of war against the Axis powers.

In May, 1941, President Roosevelt declared an unlimited national emergency and seized Axis-owned or controlled ships in American ports. After the sinking of the American merchantman "Robin Moor" on May 21, 1941, by a 
German submarine, the President froze German and Italian assets in the United States and ordered their consulates closed.

The undeclared naval war between Germany and the United States intensified through the summer of 1941. In July, American troops occupied Iceland; and in September, President Roosevelt issued a shoot-on-sight order for German U-boats. Though isolationist groups decried the administration's obvious violations of neutrality and international law, most Americans apparently favored aid to Britain, even at the risk of involving themselves.

Hans Thomsen, the German Chargé, understood the climate of American public opinion probably better than any other German diplomat. He was cognizant of the dangers inherent in the attitudes of the political leaders of his own country, who evidently had preconceived notions regarding the power of the united states and its ability to institute substantial military interference in Hitler's plans. Between 1939 and 1941, Thomsen was forced to deal with increasing hostility from America, and an American image of Germany which more and more depicted the Third Reich as the enemy and a nation grasping for world domination. It comes as no surprise then, that Thomsen viewed the Abwehr activities in the United States with distaste and felt they could only jeopardize what were already antagonistic foreign relations.

Thomsen felt that many of the spies he was familiar 
with were unsuited for espionage activity and he feared that the exploitation of acts of German espionage would be used to further anti-German propaganda and perhaps to justify America's entry into the war. Thomsen felt the United States could be driven into a war, and used 1917 as an example, when, he claimed, American public opinion was incited as much by alleged and actual cases of sabotage as by Germany's unlimited submarine war. (48)

Early in 1940, two men claiming to be Abwehr free-lance agents came to the German embassy in Washington asking for money. The two agents, Hausberger and Bergmann, claimed to have received instructions from the Abwehr's Major von der Osten to organize a sabotage ring in the United states. (49) Thomsen was angry not only because the Abwehr had spies and saboteurs in the United States, but because they had employed agents with so little wit and tact, who thought it natural to come to the embassy begging for funds.

Thomsen saw the Abwehr's activities as one of the surest ways to bring about direct participation of the United States in the war. Seeing it as his task to prevent America's entry into the conflict, he asked that the Wehrmacht terminate Abwehr activities in America. (50) Admiral Canaris claimed the bumbling agents were not his, and denied that any orders had been given for sabotage operations in the United States. (51) It was further stated that the OKW shared the Foreign Ministry's political 
objections to sabotage, and it was reiterated that no instructions had been given for such activities in the United States. As far as Canaris and the Abwehr were concerned, the statements of Bergmann and Hausberger were untrue. (52) An irritated Thomsen cabled back that if Hausberger and Bergmann were liars, then where did they get their explosives, and who was representing himself falsely as the Abwehr's Major von der Osten, who it was claimed, gave the two would-be saboteurs their instructions?(53)

These accusations and denials could have gone on indefinitely. The Abwehr did not want to admit to anything that would get it into trouble, and it was clear that Thomsen's objections regarding the blundering and ineffectual Abwehr agents who were jeopardizing American neutrality, were damaging and were bound to reach influential ears. The German state Secretary, Ernst von Weizsaecker, to whom Thomsen reported, was concerned over the entire incident, since as late as April, 1940, Admiral Canaris had assured Ribbentrop that the Abwehr had no agents in the United States spying on the American army or navy. (54) Thomsen felt it was imperative that the Abwehr refrain from their activities and Canaris was asked to follow up on the agents whom Thomsen described as, "...totally unsuited for the job...."(55)

On June 10, 1940, the Abwehr suddenly remembered that it had employed the two agents as "observers," not as saboteurs, and that under the circumstances, the two men 
should return to Germany. (56) Thomsen had won this particular battle, but not the war. The Abwehr continued to operate agents in the United States and Thomsen continued to rail against what he perceived as threats to American neutrality. Just ten days after the Abwehr admitted to hiring Hausberger and Bergmann, a new agent from Weisbaden arrived at the embassy and requested advice on where and how to install his shortwave radio, and also asked for support from the embassy in case of trouble with the American authorities. Thomsen's response to the OKW stated that, "...if the German military authorities must keep this method of procuring information, their agents must be prevented from contacting the German Diplomatic Missions."(57) When the arrests of the Duquesne and Ludwig rings were made in the summer of 1941, Thomsen wrote to the Foreign office:

Intelligence agencies in Germany indiscriminately trained totally unqualified persons and sent them to the United States. The operations of the German agencies were marked by naivete, carelessness and lack of coordination. (58)

It was Thomsen's impression that the operations conducted by these irresponsible and incompetent agents had not benefitted Germany's conduct of the war, and had certainly cost them the sympathy of the Americans. (59)

In september, 1941, the OKW formally objected to the criticism of the activity of the Abwehr in the United States made by the German embassy in washington, but by then any discussion of the problem was, for the most part, academic. The arrests of the members of the Ludwig and Duquesne 
espionage groups by the FBI effectively shut down the American-based spy rings so painstakingly developed by the Abwehr. Thomsen's attentions by then had turned elsewhere. He was preoccupied with what had essentially become the fiction of American neutrality, and the policies of the Roosevelt administration which clearly indicated that Germany's war with Britain ultimately meant American involvement. 
NOTES FOR CHAPTER IV

1. For William G. Sebold: Federal Bureau of Investigation, "Frederick Joubert Duquesne, et al Espionage" (Washington, D.C., May 5, 1953), 1-3; Farago, Game of Foxes, 406-407; Kahn, Hitler's Spies, 331.

2. For William G. Sebold: FBI, "Frederick Joubert Duquesne," 1-3; Farago, Game of Foxes, 408; Kahn, Hitler's Spies, 331; Sayers and Kahn, Sabotage, 24.

3. Farago, Game of Foxes, 408.

4. Ibid., 409; Sayers and Kahn, Sabotage, 25; FBI, "Frederick Joubert Duquesne," 3.

5. Kahn, Hitler's Spies, 332; FBI, "Frederick Joubert Duquesne," 4 .

6. Farago, Game of Foxes, 410.

7. Alan Hynd, Passport to Treason (New York, 1943), 39.

8. Ibid., 53.

9. Sayers and Kahn, Sabotage, 30; Farago, Game of Foxes, 413.

10. Farago, Game of Foxes, 409; FBI, "Frederick Joubert Duquesne," 6 .

11. FBI, "Frederick Joubert Duquesne," 9; Kahn, Hitler's Spies, 333.

12. Farago, Game of Foxes, 590; FBI, "Frederick Joubert Duquesne," 9 .

13. FBI, "Frederick Joubert Duquesne," 7-8.

14. Ibid., 9 .

15. Farago, Game of Foxes, 375.

16. Sayers and Kahn, Sabotage, 41.

17. FBI, "Frederick Joubert Duquesne," 9; Farago, Game of Foxes, 375; Sayers and Kahn, Sabotage, 41; 
"German Espionage and Sabotage Against the United states," 34 .

18. Farago, Game of Foxes, 414.

19. Ibid., 553; Hynd, Passport to Treason, 47.

20. Sayers and Kahn, Sabotage, 41 .

21. Ibid., 41; Farago, Game of Foxes, 553.

22. Farago, Game of Foxes, 553.

23. Ibid., $49,51$.

24. Kahn, Hitler's Spies, 328-331; FBI, "Frederick Joubert Duquesne," 21-22; Farago, Game of Foxes, 56-61; Charles wighton and Gunther Peis, Hitler's Spies and Saboteurs (New York, 1958), 28-29.

25. Sayers and Kahn, Sabotage, 27; Farago, Game of Foxes, 61; Wighton and Peis, Hitler's spies and Saboteurs, 32 .

26. FBI, "Frederick Joubert Duquesne," 23.

27. Farago, Game of Foxes, 59.

28. FBI, "Frederick Joubert Duquesne," 24.

29. Ibid., 27-29; Farago, Game of Foxes, 59, 374.

30. Federal Bureau of Investigation, "Kurt Frederick Ludwig, Espionage-G" (Washington, D.C., March 11, 1943), 8.

31. Farago, Game of Foxes, 541 .

32. FBI. "Kurt Frederick Ludwig," 12.

33. Farago, Game of Foxes, 543.

34. FBI, "Kurt Frederick Ludwig," 26-27.

35. Ibid., 24 .

36. Ibid., 16 .

37. Edward C. Aswell, "The Case of the Ten Nazi Spies," Harper's Magazine, CLXXXV.1105:4-5 (June, 1942); for example see: Chrysler Corporation-Dodge Division, Instruction Manual: Dodge Trucks $1 / 2$ Ton $4 \times 4$ Chassis, Built For United States Army (Detroit, Michigan, 1941); Victor Page, Lieut. Colonel Air Corps Reserve, Airplane Inspection 
Repair and Maintenance (New York, 1937).

38. Aswel1, "Ten Nazi Spies," 6; FBI, "Kurt Frederick Ludwig," 18-19.

39. Aswel1, "Ten Nazi Spies," 5; FBI, "Kurt Frederick Ludwig," 17 .

40. Hynd, Passport to Treason, 121-122, 131.

41. FBI, "Kurt Frederick Ludwig," 16-17.

42. Ibid., 3, 20 .

43. Sayers and Kahn, Sabotage, 33.

44. Hynd, Passport to Treason, 81; for example see: Aeronautical Chamber of Commerce of America, Inc., The Aircraft Yearbook of 1935 (New York, 1935).

45. Sayers and Kahn, Sabotage, 33, 35; Farago, Game of Foxes, 572 . 411 .

46. Documents on German Foreign Policy, D: IX:393,

47. Kahn, Hitler's Spies, 55, 70.

48. Documents on German Foreign Policy, D:VIII:89, IX $: 398$

49. Thomsen to German Foreign Ministry, 765/270416-270417, T-120/371.

50. Ibid., 765/270413-270415, T-120/371.

51. Documents on German Foreign Policy, D:VIII:700, IX $: 410$.

52. Ibid., D:IX: 491 .

53. Thomsen to German Foreign Ministry, 765/270426, $\mathrm{T}-120 / 371$.

54. Farago, Game of Foxes, 373-374.

55. Ibid., 547-548.

56. Documents on German Foreign Policy, D:IX:543.

57. Ibid., D: IX: 636 .

58. Ibid., D:XIII:98. 
59. Ibid., D:XIII: 98 . 


\section{CHAPTER V}

"THE GREATEST SPY ROUNDUP IN U.S. HISTORY"

In a series of arrests beginning on June 28 , 1941, the members of the Duquesne ring were taken into custody by the FBI. J. Edgar Hoover made the first announcement of what he described as, "the greatest spy roundup in American history..."; and by June 30, the Abwehr knew that thirty-three individuals associated with Duquesne had been arrested.(1)

William G. Sebold was, of course, instrumental in the breakup of the Duquesne ring. Because Sebold took advantage of the lax security within the Abwehr's American organization, and the social club atmosphere where everyone knew everyone else, the FBI was aware of other individuals operating in the New York area. However, Kurt Ludwig and his eight associates were not picked up until August. The Ludwig group had been monitored as a separate case by the FBI, for although the agency knew various spies were operating apart from the Duquesne group, they were unsure of the scope and extent of this second spy ring.

Ludwig communicated his intelligence primarily by letter through neutral country mail drops to Germany. He had a shortwave radio installed in his car and through it received instructions from the Abwehr. (2) He also made use 
of a radio center in the Bronx set up by Axel Wheeler-Hill. Ludwig rarely, if ever, used sebold's radio to send intelligence to the Abwehr. Thus the big break for the FBI on the Ludwig case came when the British secret service turned over a series of letters intercepted by British censors in Bermuda. All the letters had been sent from New York and signed "Joe K."(3) When the letters were tested chemically, the exposed message revealed that "Joe K." knew a great deal about American aircraft production and the identities of ships and their cargoes destined for Great Britain. (4)

Despite the clues contributed by the British and the "exhaustive efforts" of the FBI, the Bureau was unable to confirm the true identity of "Joe K." However, their search was aided when a man named Julio Lopez Lido was run down and killed by a taxi in Times Square on March 18, 1941. Lido's companion was seen taking the dead man's briefcase following the accident, and apparently tried to gain possession of Lido's luggage from his hotel after learning of Lido's death. (5) Investigation after the accident--including a close examination of Lido's luggage--revealed that Julio Lido was actually Ulrich von der Osten of the German military intelligence service.

Osten had come to the United States at the behest of Admiral Canaris to act as resident director of Abwehr agents, with orders to coordinate agent activities and improve overall organization.(6) Kurt Ludwig was of course, 
Osten's companion, the man who had taken Osten's briefcase, and who attempted to gain access to Osten's luggage. When a letter to Germany from "Joe K." was intercepted--again by British censors--describing Osten's accident, federal agents were able to put the letter and the results of the investigation of Osten's death together and come up with Ludwig as the identity of "Joe K."

FBI records confirm their knowledge of a connection between the Duquesne group and Ludwig; in fact, Ludwig was present at the arrest of two members of the Duquesne ring in a bookstore in New York City on June 28, 1941.(7) Before the arrest, the federal agents had observed Ludwig conferring with the two spies, but, "...pretended not to notice him and allowed him to continue with his activities, he being under surveillance, of course." (8)

Following the arrests of Duquesne and his company, Ludwig did little to merit FBI surveillance. Ironically enough, the Abwehr warned Ludwig to avoid relations with William Sebold--"Tramp"--lest he jeopardize Sebold's security.(9) Ludwig stopped all espionage activities until August, 1941, when during a trip across the country, his "inborn espionage instincts" caused him to take note of military camps and other defense establishments of interest to the Abwehr. (10) His cross-country trek was closely followed by the FBI, and when it became apparent that Ludwig's aim was to attempt to leave the united States for Germany by way of Japan, he was arrested in Cle Elum, 
Washington.

The trial of Frederick Joubert Duquesne and his thirty-two co-defendants began in September, 1941. Fourteen of the defendants, including Lang and Duquesne, entered pleas of not guilty, despite the movies, photos, recordings, and other incriminating evidence amassed by the FBI. The thirty-three defendants were indicted for violating the espionage statutes and for violation of the Federal Registration Act. All were convicted and collectively received more than 300 years in prison and were assessed fines amounting to $\$ 19,000$.(11) Duquesne received a term of twenty years and a fine of $\$ 2,000$; Hermann Lang received a term of twenty years; Everett Roeder was sentenced to sixteen years and Lilly stein twelve years.(12)

The only real drama in the trial was supplied by the appearance of William G. Sebold, who surprised his fellow agents and his Abwehr employers by revealing that he and his espionage activities were part of an FBI undercover operation. Sebold's testimony caused an uproar within the Abwehr, particularly since German intelligence had detected nothing that indicated Sebold's FBI affiliation. (13) In using Sebold, the Abwehr had neglected to take even the most elementary of precautions, and relied instead on the Gestapo's assurances that sebold had "volunteered" and was thought to be a good candidate for espionage work. This said little for the Abwehr's screening process. The fact that Sebold was able to identify Major Ritter as the man who 
hired him, and finger everyone in the Duquesne ring, as well as various other individuals, indicated that the Abwehr's security system was extremely poor.

There was evidently a strong sense of immunity among the German agents in America, because they had been able to operate for so long without challenge by the American authorities. More and more agents were recruited who were not properly instructed in the precautions important to an operative's security. It is particularly obvious in the case of the Duquesne group that members violated the most important of espionage principles: that of isolation. There was no conscious effort within the group to keep anything a secret, and that made Sebold's job all the easier.

The trial of Kurt Ludwig and his eight associates began on February 3, 1942, the first spy trial held in the United States after the attack on Pearl Harbor and after Germany's declaration of war on America. The nine were indicted on charges of conspiracy to violate the espionage statutes, and all were convicted. Lucy Boehmler, who turned state's evidence and became the government's chief witness, received the lightest sentence, five years. Kurt Ludwig, Rene Froehlich, and Paul Borchardt were each sentenced to twenty years. Helen Mayer, Karl Mueller and Hans Pagel received terms of fifteen years each; Frederick Schlosser received twelve years and Karl Schroetter, ten years. (14) Media coverage of both trials was heavy. Following the Rumrich trial in 1938 and the outbreak of war in Europe 
in 1939, America had essentially declared open season on German spies and saboteurs. On September 6, 1939, President Roosevelt issued a directive which placed the FBI in charge of investigating all suspected espionage and sabotage within the United States.(15) Local police authorities throughout the nation were instructed to give the FBI all possible aid. The nation-wide spy hunt and the publicity generated by the spies, heightened awareness of who and what to look for. A natural consequence was that nearly every public-minded citizen fancied himself a counterespionage agent in league with the FBI.

Books, magazines, and newspapers produced facts and figures which cited accidents, fires, and explosions on ships, trains, in defense plants, navy yards, airbases and army camps, and hinted that the cause was sabotage. (16) Everyone wanted to know whether or not the nation was overrun with Nazi spies and saboteurs. With so many arrested at once in late 1941, the answer seemed obvious. Thus, most people were interested in the captured spies, and there was a great deal of public fascination in their appearance, their past operations, and their trials. As was most often the case, the American public received its detailed information from newspapers, magazines and books, media that sometimes used stereotypes and sensationalism to heighten interest in the story.

American readers were told that, "...some of the spies working for Hitler were known to consider an autographed 
photo of their Führer the most precious reward they could ask."(17) Lilly Stein of the Duquesne ring was described as a "...willowy person of about thirty who might have been pretty had it not been for a sneer that constantly played about her lips."(18) The FBI claimed Stein had aspirations of "...attaining fame as a second Mata Hari..."(19) Rene Froehlich was slurred less subtly: "Rene didn't have a bad first name--for him. It could have been a girl's name, and Froehlich walked like a girl."(20)

During the Ludwig trial, a description of Helen Mayer listed her eyes as too small and too close together and her nose as long, bony, and pointed.(21) In fact, the reader was asked to make note of how the facial pattern was repeated in a number of the faces of those on trial.(22) It was noted that the government's chief witness, Lucy Boehmler, had a cool and withdrawn quality about her. This was attributed "...to the essential cold-bloodedness of her nature. She spied for the fun of it."(23)

The characteristics of the FBI agents instrumental in the apprehension of Ludwig were quite different than those attributed to the German spies. The Bureau operatives at the trial were:

...young, intelligent, sure of themselves in a quiet, competent way. All of them seemed to be college graduates, and each man had had special training in the work he was assigned to do. They had the straight, clear eyes, the firm jaws, the steady look of men to whom life is a perilous adventure and who are not afraid of it. (24)

Obviously the FBI was viewed as the nation's paramount 
counterespionage agency, and the prime power which had "smashed" the enemy's spy rings. However, the position of the FBI was not as omnipotent as was believed, nor were the successful arrests attributable only to the efforts of the Bureau.

The initial investigation of the Duquesne ring can be ascribed to the willingness of William sebold to act as an inside informer for the FBI. Sebold was not obligated to work with the American authorities, but volunteered on his own initiative, though he knew his activities could endanger his family still in Germany. Similarly, the Ludwig case was initially broken by the British censorship authorities who gave their information to the FBI. The Federal Bureau of Investigation was not an inept organization, but despite J. Edgar Hoover's accolades, the Bureau was not cracking cases on its own.

The era of Frederick Joubert Duquesne and Kurt Ludwig was the most successful for the Abwehr in America. Following the large-scale arrests of Abwehr spies in the summer of 1941, German espionage activities in the United States were sharply curtailed and the Abwehr was never again able to establish agents as firmly or acquire intelligence on the same scale. However, it has been clearly indicated that much of the intelligence gathered by Germany's spies in America came from relatively public sources, and additionally, after 1940, the FBI controlled sebold and thereby controlled most of the intelligence information that 
left the United States. The Abwehr agents made use of various technical journals, visually recorded shipping activities in the harbors and on the docks, and gathered verbal as well as written information concerning defense plants, military installations, and the war potential of the United States. True, Hermann Lang stole most of the blueprints of the Norden bombsight and Everett Roeder managed to obtain a great deal of technical data due to his position at the Sperry Gyroscope plant, but these individuals and their acquisitions were relatively unique. Most of the information gathered by the spies was readily available from the press and other sources which were open to practically anyone in the United States; but the significance of this knowledge was strongly dependent upon how it was interpreted. Thus the value the Germans put upon the intelligence from America was determined by the manner in which their intelligence agencies evaluated and made use of the material.

It would be inaccurate, however, to state that Germany's espionage activities in the United States prior to Pearl Harbor were a complete failure. Information was received by the Abwehr from William Lonkowski, Ignatz Griebl, Frederick Duquesne, Hermann Lang, Everett Roeder, and Kurt Ludwig among others; information which the Abwehr passed on to the evaluating agencies of the OKW. However, after 1940, the FBI had control of much of the information sent out of the United States, particularly that which went 
through sebold. It is also interesting to note that many of these German evaluation agencies found that the agent's reports were probably the least valuable of their major sources, and were considered by some commanders to be far below radio reconnaissance, prisoner interrogation, and the press in comparable quality and accuracy.(25) Undoubtedly this was due to the Abwehr's lack of true examination of its agent's reports before they were sent in. This was most evident in intelligence information which came from Britain, all of which was in some way tampered with since all of the German spies in England were double-agents under the control of the British authorities. (26)

Despite the publicity surrounding the arrests and trials of the Duquesne and Ludwig spy rings, the American public was unable to determine from available sources how effective German espionage in the United States actually was. Nevertheless, American citizens were kept aware of the real or imagined dangers espionage agents and saboteurs held for the United States. Some of the more sensation-seeking books and articles claimed for example, that the sinking of the merchantman "Robin Moor" in May, 1941, and the destruction by fire of the liner "Normandie" in February, 1942, were due respectively to Nazi spy reports and sabotage. (27)

Hollywood too, contributed to the public's concept of who the enemy spies were and what they were up to. A number of films were cranked out, among them "Confessions of a Nazi 
Spy," released in 1937, "Saboteur," and "Dawn Express," in 1942, and "Watch on the Rhine," released in 1943. These films chronicled Hollywood's version of Nazi espionage and sabotage in America, and served to keep the spy image larger than life by ascribing some rather outlandish behavior to the Nazi agents operating in the United States. The films were pure Hollywood camp, portraying a few stalwart Americans single-handedly defeating dozens of enemy spies. In the war according to Hollywood, it was often the amateur who apprehended enemy spies and saboteurs, while officials followed false leads.(28) But whatever the quality of its films, Hollywood was consistent in its portrayal of Nazism and its adherents as absolutely evil. Popular fiction also reinforced the view of the evil Nazi, often depicting arrogance and cruelty as common German characteristics. John Steinbeck's The Moon is Down, published in 1942, told the story of a Norwegian town taken over by the Nazis, and is a good example of the strain of anti-Nazi literature common in America at the time that pitted the courageous forces of good against wickedness. (29) In the months following Pearl Harbor the publicity generated by enemy spies had a strong effect on the American public, as evidenced by the unofficial help given the FBI by members of the populace. Americans were rightly warned about the serious effects indiscriminate talking about troops, ships, planes, production, fortifications, and even the weather could have on the war effort. But even these 
righteous cautions served to instill feelings in the united States that spies could, and probably were, operating everywhere. No one really knew what information the enemy considered valuable, therefore anything could be construed as a military secret.

However, the effort to be patriotic sometimes took a ludicrous turn, as when the FBI received letters from helpful Northwesterners telling how Japanese disguised as salmon were swimming up the Columbia River.(30) Federal agents were also advised by anxious citizens that German spies were communicating with each other through the water faucets.(31) Other stories investigated by the FBI included reports of landings by enemy parachutists, civilian fears that saboteurs were putting ground glass into food products, and finally that mysterious flashing lights were German spies signaling each other.(32) Examination by the FBI disproved each allegation, yet these stories confirm the fact that a state of anxiety generated by the presumed threats posed by enemy spies and saboteurs existed in the minds of many Americans.

The average American was bombarded with factual and fictional information about Nazis and enemy agents from movies, books, magazines, and newspapers; nevertheless citizens were particularly admonished not to discuss or repeat anything true or untrue about spies or saboteurs operating in the United States.(33) It was believed that any loose discussion about the opposition's espionage 
activity could serve as a means of spreading panic around the country. (34)

Yet those same sources that claimed to be fighting the war against spies and saboteurs acted almost as a catalyst in furthering spy hysteria in America. Americans were advised that the German psyche allowed no mercy to be shown to the enemy. (35) It was further stated:

Saboteurs and fifth columnists in this country will stop at nothing. Poisoned water supply systems, poisoned milk for babies, blasts of huge magnitude in schools and department stores and other panic centres[sic]; bombs planted in the homes of high government officials, chemical poisons unleashed against men in army and naval training centres[sic]; wholesale murders of key war production workers--all that is definitely on the German sabotage timetable.(36)

As the United States geared up to join the war effort against Hitler, there was a strong current of emotion against the "Nazi terror," and a belief that the war would encourage German espionage agents to work to undermine and ultimately destroy the United States. It was impossible to know that by 1942, the Abwehr and the Third Reich had already played out their strongest cards. Adolf Hitler's attempt to quickly conquer the Soviet Union had already failed, and on December 11, 1941, Hitler ignored the lessons of history, underrated the power of America and declared war on the United States. The Reich that was to have endured for a thousand years was destined to fall much sooner. Admiral Canaris' Abwehr would survive an even shorter period. 
German spying in America was far from the omniscient, all-pervading activity that many believed in and feared. True, the arrests and trials of German spies in 1938, late 1941, and early 1942 confirmed that spying had occurred in the United States, yet these facts were reinforced by a visual and written message to the American people that not only boosted a heartless and depraved image of the Nazi, but also suggested that these "treacherous" and "insidious" spies were everywhere, working to undermine the world's foremost democracy. Thus, for many Americans, truth was augmented by wild rumor, rumor fanned by apprehension, and what was believed took precedence over fact. 
NOTES FOR CHAPTER V

1. Farago, Game of Foxes, 578-579; Telegram to German Foreign Ministry, 765/270434-270446, T-120/371.

2. FBI, "Kurt Frederick Ludwig," 4; Farago, Game of Foxes, 544 .

3. FBI, "Kurt Frederick Ludwig," 2 .

4. Ibid., 2; Farago, Game of Foxes, 574.

5. FBI, "Kurt Frederick Ludwig," 2, 6; Farago, Game of Foxes, 573-574; Aswell, "Ten Nazi Spies," 2.

6. Farago, Game of Foxes, 569.

7. FBI, "Kurt Frederick Ludwig," 10.

8. Ibid., 10 .

9. Farago, Game of Foxes, 578 .

10. FBI, "Kurt Frederick Ludwig," 4.

11. FBI, "Frederick Joubert Duquesne," 1.

12. Ibid., 9-10, 22, 24, 29 .

13. Thomsen to German Foreign Ministry, 765/270499-270500, T-120/371; see also Memorandum from Canaris, 765/270564, T-120/371.

14. FBI, "Kurt Frederick Ludwig," 5.

15. Sayers and Kahn, Sabotage, 120.

16. Ibid., 109-119.

17. Hynd, Passport to Treason, 97.

18. Ibid. , 48 .

19. FBI, "Frederick Joubert Duquesne," 29.

20. Hynd, Passport to Treason, 120.

21. Aswel1, "Ten Nazi Spies," 5. 
22. Ibid., 5 .

23. Ibid., 7 .

24. Ibid., 14 .

25. Kahn, Hitler's Spies, 364 .

26. See: J.C. Masterman, The Double-Cross System in the War of 1939-1945 (New York, 1972).

27. Hynd, Passport to Treason, 151; Sayers and Kahn, Sabotage, 99-105.

28. John Morton Blum, V Was For Victory (New York, $1976), 36$.

29. John Steinbeck, The Moon is Down (New York, $1942)$.

30. Irwin, What You Should Know, 207.

31. Ibid., 207.

32. Ibid., 213-214.

33. Ibid., 207.

34. Ibid., 212.

35. Hynd, Passport to Treason, 306.

36. Ibid., 306 . 
OPERATION PASTORIUS

When the United States finally became involved in the war in December, 1941, following the Japanese attack on Pearl Harbor and Germany's declaration of war, Abwehr I was virtually without any good American agents. The majority of spies under their control in the United States were taken out of action by the FBI in the summer of 1941. As a result, when Adolf Hitler began insisting in 1942 that a program of sabotage be instituted against the United States, Admiral Canaris and General Erwin von Lahousen, who headed the sabotage division of the Abwehr, decided that saboteurs from the Reich would have to be landed on America's shores. (1)

The magnitude of the war to which they were officially committed increased the awareness of Americans to the dangers posed by enemy saboteurs. Americans were warned that much of Hitler's early successes were aided by the internal collapse of the countries he invaded and ultimately conquered, breakdowns which were precipitated by the actions of German fifth columnists and saboteurs.(2) Americans took much solace in the fact that their world was separated from that of their enemies by two oceans, yet there was a very real fear of sabotage and treachery from within as evidenced 
by the way Americans and their leaders reacted to the highly visible Japanese-American section of the population. Germans living in the United States were spared the internment camps and the sort of prejudice directed against the Japanese; but Nazi Germany remained the power that excited the highest suspicions, and its purported control over its nationals abroad generated fear. The specter of Sabotage, published in December, 1941, stated:

The Nazis know the whereabouts of nearly all German nationals in the United States and past experience teaches us that Germany is the specialist among nations in the murderous business of sabotage and espionage. To the Nazis, therefore, goes the dubious distinction of heading the list of those from whom we have most to fear in any consideration of the threat of sabotage. (3)

The Abwehr chose the candidates for a sabotage mission to the United States from the files of the "Deutsches Ausland-Institut." Lahousen wanted men who spoke English, had lived in America, and were familiar with American customs, and the "Ausland Institut" was a good place to look for individuals with these qualifications. A pre-Nazi organization formed in 1917, the "Ausland-Institut" had originally operated as a propaganda agency, but changed its function after World War $I$, when it began collecting information on other countries to help Germans find opportunities overseas. After Nazification, the "Ausland Institut" continued collecting information on foreign countries from German residents abroad. It also held extensive files on Germans who had lived abroad but had 
returned to Germany. The functions of the "Ausland Institut" under the Nazis confirmed that Germany had knowledge of, if not control over, many Germans living outside the Reich.

The man Lahousen appointed to recruit the would-be saboteurs was Lieutenant Walter Kappe, an officer of Abwehr II, the sabotage division. Kappe had lived in the United States from 1925 to 1937, had been active in pro-Nazi groups, and was instrumental in forming "Teutonia," the first national Nazi organization in America.(4) As the National Socialist party in Germany became more powerful, "Teutonia" became the Friends of the Hitler Movement, the Friends of the New Germany, and finally the German-American Bund. Kappe was named Press and Propaganda Chief of the organization in 1933, but apparently tried and failed to overthrow the American Führer, Fritz Kuhn, and was thrown out of the group in $1937 .(5)$

Upon returning to Germany, Kappe became propaganda director for a radio station in Berlin which broadcast to North and South America. When war came he served a short time in the army before being assigned to the Abwehr. Because Kappe himself had lived in the United States for a number of years, he worked with the files of the "Ausland-Institut," paying particular attention to those repatriated Germans who had also lived in the United States. Hostility between the United States and Germany had increased dramatically between 1939 and 1941, and naturally 
the Nazis were interested in those individuals who had spent time in America and who were familiar with the country.

After a long process of interviews and eliminations, Walter Kappe selected twelve men from the records of the "Ausland-Institut" for a sabotage mission to the United States. The codename for the project was "Pastorius," named after Daniel Pastorius, the leader of one of the first groups of immigrant Germans to land in the United States almost 260 years before. (6)

Kappe arranged to have all twelve men transferred from their assorted posts in the army or in defense plants to the Abwehr's sabotage training school at Quentz Lake in Brandenburg. There they spoke only English and underwent three weeks of instruction on the various methods of destroying industrial targets in America. The men were educated in general chemistry, learned how to combine incendiary mixtures and how to ignite them. They studied different kinds of fuses, detonators, and primers, as well as electrical, mechanical, and chemical timing devices. (7) The men were tested under realistic conditions in finding their targets, deciding whether to use an explosive or an incendiary device, how much to use, and finally, escaping detection. Kappe and his men toured lock gates on rivers and canals, railroads, and a few of Germany's major aluminum and magnesium plants, including the I.G. Farben aluminum plants in Bitterfeld. The saboteurs were instructed about the vulnerability of these sites and were shown which key 
points were most susceptible to damage. (8)

The saboteurs were also drilled daily in their personal, albeit fictitious, biographies. If questioned, the saboteurs were to maintain they had never left America, and were given forged Selective Service cards and letters with American stamps and recent postmarks to carry. (9) In addition, the men were instructed in the making of invisible inks and the use of secret writing for communication through the regular mail.

The three week training period served to weed out those who showed no aptitude for sabotage work. Kappe dismissed three of the original twelve, and divided the remaining nine into two groups. George John Dasch was appointed the leader of one group, Edward John Kerling the other.

At thirty-nine, George Dasch was the oldest member of the sabotage group and had spent nineteen years in the United States--more than any of his companions. Dasch had been born in the Rhineland and had served Germany in the last year of the First World War. Like many of his countrymen, he found Iife in Germany hard after defeat in 1918, and in October, 1922, entered America as a stowaway. (10)

Dasch worked as a waiter and a dishwasher in restaurants and hotels around the country, and in 1927 joined the United States Army Air Corps. After serving a little over a year, Dasch purchased his way out of the army 
and received an honorable discharge and an "excellent" character rating.(11) He married an American woman shortly after leaving the army, and later filed a declaration of intention to become a citizen of the United States, but never filed the final citizenship papers.

In 1941, Dasch left New York City for San Francisco, traveled by boat to Japan, and by railroad overland through Manchuria and Russia to Berlin, where he arrived on May 13 , 1941. Dasch was employed in Germany by the "Sonderdienst Seehaus," a radio monitoring service which operated under the combined auspices of the offices of Goebbels and Ribbentrop. (12) Since the "Sonderdienst Seehaus" listened to foreign broadcasts, its employees had to know a foreign language well, be fairly up to date on the politics and customs of the country whose broadcasts they listened to, and be able to translate what they heard into German. Consequently the "Seehaus" preferred to hire Germans who had lived abroad. Dasch listened to American news broadcasts for approximately six months before he was approached by Walter Kappe as a prospective candidate for a sabotage mission to the United States. Dasch was placed under Kappe and transferred to Abwehr II in February, 1942.

Edward Kerling was born in Wiesbaden, Germany in 1909, and became an early member of the Nazi Party in 1928. Kerling came to the United States on an immigrant quota visa and worked primarily as a chauffeur and a domestic servant. He married a German-born woman in America, and apparently 
was active in the German-American Bund. (13)

Shortly after the war in Europe began, Kerling and a few Bundist friends--including Hermann Neubauer who would later join Kerling on the sabotage mission to the United States--purchased a sailboat, the "Lekala," with the intention of returning to Germany to help its war effort. The yawl and its passengers were investigated by the coast Guard, the FBI, and Immigration and Customs officials for possible violations of American law. Kerling was ordered to dispose of the boat, and shortly after its sale in June, 1940, he departed for Germany on the SS "Exchordia." (14) Like Dasch, Kerling obtained employment as a translator of English-language radio broadcasts. He went from there to a position in the Propaganda Ministry in Berlin. (15)

Kerling was approached by Kappe in March, 1942, and interviewed for what he was informed was a secret "military mission" in the United States. Kerling agreed to what he thought would be a commando raid carried out by soldiers in uniform. He was not apprised of the sabotage mission until he arrived at the training center in Brandenburg. (16)

Dasch and his group of four were to land off the coast of Long Island, New York. His companions included: Ernest Peter Burger, Joseph Schmidt, Heinrich Heinck, and Richard Quirin.

Apart from the two group leaders, Ernest Peter Burger was the most important member of the mission, for it was Burger whom Kappe appointed to set up a front to serve as a 
communications center for the sabotage mission. Burger was also to maintain written, coded contact with Kappe and the Abwehr, since walter Kappe himself planned to come to the United States and direct sabotage operations as soon as all the groups he intended to send over were stabilized.

Burger was born in 1906 in Bavarian Germany, joined the Nazi party early, and marched with Hitler in the Munich Beer Hall Putsch of 1923. As a member of Hitler's brown-shirted "Sturmabteilung"--storm detachment--or SA, Burger fought in innumerable street battles. During peaceful interludes, he completed his technical education and worked as a machinist. In 1927, Burger came to the United States on an immigrant visa, found employment as a machinist, joined the National Guard, and became a naturalized citizen. (17)

Burger returned to Germany after Hitler's appointment as Chancellor in 1933, and was attached to the staff of Ernst Robm, head of the SA. Burger escaped the purge of the SA on June 30, 1934, and eventually found employment in the domestic propaganda branch of the Party. In March, 1940, Burger was arrested by the Gestapo and accused of falsifying government documents, apparently for critical remarks contained in a geopolitical report he wrote concerning the Gestapo's activities in Poland. He was released in July, 1941, drafted as a private in the army, and was engaged in guarding British and Yugoslav prisoners-of-war when his name was discovered by Kappe in the files of the 
"Ausland-Institut." (18)

Heinrich Heinck and Richard Quirin were both born in Germany, and both had received training as machinists. In 1927, the two men had come to the United States--Quirin legally as an immigrant, Heinck illegally after jumping ship. Heinck and Quirin joined the Bund and its storm troop division, the "Ordnungsdienst." In 1939, both men took advantage of Germany's offer to pay the expenses of those who wanted to return to the Reich. They finally met at the Volkswagen plant in Braunschweig where they were assigned to work. Heinck and Quirin were recruited for the sabotage mission by Walter Kappe who, representing the "Ausland-Institut," had lectured those employees at Braunschweig who had once lived in the United States. (19) Joseph Schmidt was the fifth member of group that was to land off of Long Island in America. He too, had been born in Germany, but left during the unsteady years of the Weimar Republic and had gone to Canada. There he had lived by hunting, trapping, and selling alcohol to the Indians. Schmidt expressed his desire to go off on his own to Canada and start forest fires, but Kappe vetoed the suggestion. Schmidt completed the training with his fellow-saboteurs and accompanied them on their final leave in Paris and to their departure point in Lorient, France. However, Schmidt found he had contracted gonorrhea during the Paris holiday, and Kappe would not let him on the close-quartered submarine.(20) With Schmidt's departure, the two groups 
were evenly matched at four each.

Herbert Hans Haupt was the youngest member of the sabotage mission. A member of Kerling's company which included Hermann Neubauer and Werner Thiel, Haupt was born in 1919 in stettin, Germany. Haupt came to the United States with his family when he was five, and became naturalized in 1930 when his father received citizenship. In June, 1941, Haupt, accompanied by a friend, left the United States for Mexico to escape a pregnant girlfriend. When their money ran out, Haupt and Wolfgang Wergin accepted the help of the German consulate which paid their fare to Japan on the pretext that there was employment for them there. Faced with work in a labor camp in Japan, Haupt and Wergin found working passage on a German freighter leaving for France, which arrived in Bordeaux on December 11, 1941, the day Germany declared war on the United States. Haupt was allowed to stay with his grandmother in Germany, but had to endure frequent questioning by the Gestapo, and the inability to acquire a work permit and find a job.(21)

Haupt was contacted by walter Kappe in early 1942 about the possibility of an article Haupt might want to write about his trip to Germany. It was during the second interview that kappe asked Haupt if he would be willing to return to the United States where" "...certain unspecified duties might be expected of him..."(22) Haupt agreed and was sent to Quentz Lake where he learned of the sabotage mission. 
Like their companions, Hermann Neubauer and Werner Thiel had been born in Germany and had come to the United States before Hitler came to power, hoping for opportunities that had not presented themselves in Germany. Neubauer arrived in America in 1931 and found work as a cook in restaurants, hotels, and on an occasional ocean liner. He became a member of the German-American Bund, and later joined the Nazi Party. He applied for his first citizenship papers but did not obtain final naturalization. (23)

In 1939, Neubauer joined Edward Kerling on the boat "Lekala" in an attempt to sail to Germany. After this plan was foiled by the Coast Guard, Neubauer and his wife returned to Germany via Lisbon in July, 1940. Neubauer was drafted into the German army and served in the Polish campaign and in the first days of the war with Russia. He was wounded and while recuperating received a letter from Walter Kappe asking if he "...would be willing to go on a secret assignment to a foreign country where he had once lived."(24) Neubauer agreed and learned of the sabotage plans in Kappe's office.

Werner Thiel was trained as a machinist and worked for the Ford plant and General Motors after coming to Detroit in 1927. He filed a declaration of intent to become a citizen but made no further attempt to receive final naturalization. Thiel lost his job when the depression struck and was forced to travel around the country picking up what work he could. During this time he joined the Friends of the New Germany 
and later the Bund. (25)

Thiel returned to Germany in the spring of 1941, and met George Dasch during the crossing. He found employment in a war plant until March, 1942, when he was approached by both Kappe and Dasch about returning to the united States to do "something."(26) Thiel was informed of the nature of the mission discussed by Kappe and Dasch when he arrived at Quentz Lake.

The equipment the two sabotage groups would carry via submarine to the United States was packed in wooden crates lined with steel to insure against water damage. The crates contained explosives, some of which were designed to look like lumps of coal. Also included in the crates were fuses, detonators, timing devices, and pen and pencil sets which were actually incendiary bombs. (27)

The men were also supplied with a quantity of American currency for expenses they were expected to accrue in the United States. Each group leader was given $\$ 50,000$ as a general fund for buying sabotage materials, travel, bribes, and other group expenses. Each of the saboteurs was given $\$ 9,000, \$ 5,000$ of which was held by the group leader. In addition all of the men received $\$ 450$ in small bills for immediate use in America.(28) However, some of the bills issued to the saboteurs had to be exchanged or discarded since they were gold certificates which had been withdrawn from circulation when America went off the gold standard in April, 1933.(29) All of the saboteurs were equipped with a 
special money belt designed by George Dasch.

While the group was to forego radio contact with the Abwehr in Germany, both Kerling and Dasch were given a white handkerchief on which was written in invisible ink the name and address of a mail drop in Lisbon through which they could communicate with Kappe. The handkerchiefs also had the names of two trustworthy people in the United states whom the saboteurs could call on for help. Kerling's information included the address of Dasch's brother in New York, and Dasch's that of Herbert Haupt's uncle in Chicago. The two leaders could communicate with each other through these mail drops until Burger had the communications center set up, and even after if circumstances warranted it. (30)

'Before they were to depart, the eight saboteurs were informed of their sabotage objectives in the United States. Because aluminum and magnesium production was important to the American war effort, specific targets included three of the plants of the Aluminum Company of America at Alcoa, Tennessee, East St. Louis, Illinois and Massena, New York. The Philadelphia Salt Company's cryolite plant in Philadelphia was also slated as a target because it provided materials essential to the production of aluminum. (31)

Vulnerable spots along the Chesapeake and Ohio railroad were to be damaged to disrupt the carrying of coal, as well as the Pennsylvania Railroad terminal in Newark, New Jersey, through which large quantities of war products and raw materials passed daily. Destruction of the Pennsylvania 
railroad's horseshoe curve at Altoona, Pennsylvania, and interference in rail transportation was stressed as an important step in crippling that state's anthracite coal industry. Other targets included: the Hell Gate Bridge over the East River in New York City; locks and canals on the Ohio River between Cincinnati and St. Louis; and the water reservoirs of New York City.(32) These were specific targets and did not represent all the mission's objectives. Aside from these goals, it was largely up to the group leaders what was to be sabotaged and when; however Kappe emphasized the importance of any acts of sabotage that would disrupt industry or damage transportation facilities and thus slow the passage of war materials. In addition, Kappe advocated a series of nuisance bombings in public spots around the country to undermine American morale.

Following the weekend in Paris where Schmidt caught gonorrhea and the rest of the men got drunk, the remaining eight saboteurs, accompanied by walter Kappe, travelled to the Lorient naval base which the Germans had occupied since June, 1940. On May 26, 1942, Kerling and his group left for Florida aboard the submarine U-584. Dasch and his group left two days later on the $\mathrm{U}-202$. The two groups arrived in the United States in the early hours of June 17 and June 13, respectively.

George Dasch and his companions landed on the beach at Amagansett Beach on Long Island. They wore German naval uniforms so they would be treated as prisoners of war and 
not spies in case they were caught. Shortly after the four men and their crates of explosives had been landed on the beach, they were approached by a patrolling Coast Guardsman, twenty-one-year-old John Cullen. Dasch told Cullen that he and his friends were fishermen who had run aground. When cullen invited them to spend the rest of the foggy night at the Coast Guard Station, Dasch refused, saying that they had neither identification papers nor a fishing permit. When Cullen insisted, Dasch threatened to kill him. After speaking of murder, Dasch abruptly changed tactics and offered cullen a bribe to "forget what he had seen." Cullen accepted the money and was about to leave when Dasch gave him the name he would be operating under in America--"George John Davis"--and oddly enough, demanded that Cullen look closely at his face. After the patrolman left, Dasch and the other saboteurs buried their German uniforms and their trunks of explosives on the beach, walked to the train station at Amagansett, and rode the train to Manhattan. (33) Kerling's group landed without incident at Ponte Vedra, Florida, about seven miles south of Jacksonville. After burying their crates of explosives in the sand, they travelled by bus to Jacksonville where they separated. Herbert Haupt and Hermann Neubauer went to Chicago, Edward Kerling and Werner Thiel to New York City by way of Cincinnati. Both groups were to establish themselves securely before taking any action, and each group was to work separately--Kerling's primarily in New York and 
Pennsylvania and Dasch's in the Midwest. Kerling and Dasch were to meet in Cincinnati on July 4 to compare progress reports and discuss sabotage plans.

When John Cullen ran back to the Coast Guard Station at Amagansett in the early morning hours of June 13, 1942, it was to raise the alarm over his confrontation with the men on the beach, one of whom had threatened his life and then had given him money. Cullen returned to the beach about twenty minutes later with a group of coast Guardsmen to search the area, but Dasch and his men were gone. The searchers could hear the diesel motor of the submarine and the smell of diesel oil was strong along the beach, but the U-boat was never clearly seen. (34) Until daylight, nothing suspicious was found except a package of German cigarettes. However, later in the morning, the searchers found the boxes of explosives and the German naval uniforms, which they turned over to the FBI. (35)

Certain that the evidence they possessed signified an invasion attempt by Nazi saboteurs, federal agents questioned residents of the area as well as known Nazi sympathizers around Long Island in the hopes that someone could corroborate the description of Dasch supplied by Cullen. With little to go on aside from cullen's testimony, the explosives, and the uniforms, it was a number of days before the Bureau could ascertain that the saboteurs had probably headed for New York City and the near anonymity of its immense population. 
Though Dasch had been instructed by walter Kappe to establish himself and his men in Chicago as soon as possible after arriving in the United States, he delayed moving his group, which upset Quirin and Heinck, both of whom disliked Dasch. Dasch reveled in his return to New York City and the power he derived from the money supplied by the Abwehr. However, unbeknownst to his companions, Dasch's plans for the sabotage mission were vastly different from those envisioned by Walter Kappe and the Abwehr. George Dasch had decided to betray Operation Pastorius; whether he decided this prior to his arrival in the United States or because he believed both he and the mission had been compromised by his encounter with Coast Guardsman Cullen, is uncertain. Whatever the reason, Dasch made his first telephone call to the FBI in the late afternoon of Sunday, June 14, little more than twenty-four hours after his arrival in America. (36)

In his initial telephone conversation, Dasch identified himself as "Franz Daniel Pastorius," and stated that he had come from Germany to New York with information he would give only to J. Edgar Hoover. The agent he spoke to gave him little encouragement, thinking, no doubt, that it was one of the many crank calls directed to the FBI. Dasch stated that he would come to Washington later in the week and deliver his information personally. (37)

Dasch had apprised only Peter Burger of his plans to wreck Pastorius, and gave Burger the option of either going 
along with him or being arrested as a spy when Dasch gave everything away to the authorities. Because of the compatibility of Richard Quirin and Heinrich Heinck, Dasch and Burger had been thrown together as partners within the sabotage group; thus Dasch saw Burger as his only choice for an accomplice, someone who would back up the story he wanted to tell the FBI. Though Lieutenant Kappe had warned each of the saboteurs that death was the penalty for revealing either what they learned in Germany or the purpose of the sabotage mission, the power of the Abwehr to enforce their punishment was small beside that of the death penalty the United States government would almost certainly mete out to convicted saboteurs. Burger for his part must have sensed that his personal survival depended on his support of Dasch's betrayal, and thus agreed to play the role of the silent partner.

Aside from a tense meeting on June 14, Dasch had avoided all contact with Quirin and Heinck, preferring to let Burger deal with the frustrations and security fears stemming from their stay in New York City. Free from the stress of maintaining the guise of one dedicated to the sabotage mission, Dasch enjoyed a thirty-six hour stint of two-handed pinochle before leaving for Washington, D.C. on the afternoon of June $18 .(38)$

He made his second call to the FBI the following morning, identifying himself as "George Davis," the leader of eight saboteurs from Germany. By this time the FBI 
offices had been informed of cullen's report and the discovery of the crates of explosives, buried on the beach at Amagansett. Agents were sent to question Dasch.

Dasch was placed in protective custody by the Bureau, and subjected to an intense period of interrogation. He not only exposed the men in his own group, but surprised the FBI with information about Kerling's group and their landing in Florida, about which the FBI had no prior knowledge or suspicion. A week after they had arrived in the United States, all four of the spies who landed on the beach at Amagansett were in the hands of the FBI.

The arrest of Kerling's group took longer, primarily because Dasch was not certain of the time of the Florida landing, or where Kerling would send the members of his group. Dasch claimed to have forgotten that ammonia fumes would activate the invisible writing on the handkerchief that contained the names of Kerling's contacts in the United States, and the Bureau laboratory had to discover the key for themselves. (39)

It was not until Tuesday, June 23 , that federal agents were assigned to watch Helmut Leiner, a close friend of Kerling's, and as his name on the handkerchief revealed, one considered reliable enough by the Abwehr to serve as a source of help to their saboteurs. FBI agents followed Leiner from his home on Long Island to New York City where he met with Edward Kerling and werner Thiel. Kerling was arrested that evening and Thiel two days later. 
The FBI did not have to search long for Herbert Haupt. He came to the FBI office in Chicago on his own initiative on the morning of June 22 , to explain his absence from the United States and to clarify his selective service status, about which the FBI had questioned his parents prior to his return to America. Haupt's cover included using his own name and maintaining that he had never left Mexico during the year he was away from America; unfortunately his well-rehearsed story was wasted on the the federal agent who listened to him. Dasch had already given Haupt's name to the FBI.

Haupt was followed in the hope that he would lead to the last of the saboteurs, Hermann Neubauer, but the two never met. Haupt was finally arrested on Saturday, June 27 , and it was only after his interrogation that the FBI was able to locate Neubauer.

Throughout his days in the protective custody of the FBI, George Dasch had apparently envisioned himself a second William Sebold; a double agent working with the authorities, aiding in the arrests of enemy saboteurs, and ultimately receiving well-deserved accolades as an American hero. (40) Unfortunately for Dasch, the FBI and the Justice Department evidently did not believe the story of his deep-rooted antipathy toward the Nazis, or that he had planned from the beginning to betray the mission in the United States. Instead, as the prosecutor in the case suggested, they believed that Dasch had gotten "cold feet" when he was 
observed on the beach at Amagansett by a member of the coast Guard shore patrol. Dasch was arrested and charged along with his seven companions, all of whom were liable for the death penalty under America's wartime regulations.

The arrests of the saboteurs were made public on the evening of June 27, 1942, by J. Edgar Hoover who assumed full credit for the FBI. Hoover played down the role of the Coast Guard, and made no mention of Dasch's confession. The report prepared by the FBI on the case, RE: GEORGE JOHN DASCH, with aliases, et al SABOTAGE, and released in November, 1942, did describe the actions taken by the coast Guard at Amagansett Beach, but again contained nothing of the voluntary confession of George Dasch, which for all purposes, solved the case for the FBI. (41)

However, at the time of the announcement the American public had little interest in the self-serving maneuvers of the Bureau, or in who or what had captured the German saboteurs. That they were in custody was enough for the majority of Americans, most of whom treated the news of the arrests as a victory of sorts--a triumph over the Nazi invaders. Public opinion was very obviously against the captured Germans, and demands for the death penalty were rife across the pages of newspapers and magazines. (42) The summer of 1942 was not a terribly successful time for America and its allies, with the Axis offensive in North Africa, the German advance in the Soviet Union, the almost constant bombardment of England, and the costly victory at 
Midway. The capture of the German saboteurs gave Americans a badly needed win, and the nation wasted no pity on those who had sought to bring the war so much closer to home. The trial of the eight men began on July 8, 1942, in Washington, D.C. Although they had been captured as civilians, the saboteurs were tried by a military tribunal composed by President Roosevelt, under the rules of court martial for military personnel. It was the aim of the Justice and War Departments to subject these confessed agents of an enemy nation to the law of war; that being a secret military trial and a certain death verdict, neither of which could be guaranteed by the civil courts. The court that judged the eight saboteurs consisted of three major generals and three brigadier generals under the leadership of Major General Frank R. McCoy. The prosecution was led by Attorney General Francis Biddle and the Army's Judge Advocate General, Major General Myron Cramer. The defense counsel consisted of Colonel Cassius Dowell and Colonel Kenneth Royall, with Colonel Carl Ristine appointed as counsel for George Dasch, since Dasch was certain to testify against the others.

All eight men were described in the official charges as being in "Violation of the Law of War," that is, that they acted on behalf of Germany to sabotage war materials and industries in the United States. The second charge was the "Violation of the 81st Article of War," which stated that the saboteurs had relieved or attempted to relieve 
enemies of the United States, and had given intelligence to enemies of the United States. The third charge, "Violation of the 82nd Article of War," concerned spying, and accused the eight men of acting as spies for the German government. The fourth charge accused them of conspiracy to commit the first three crimes. (43)

Because the United States was at war and because of the method and manner in which the trial was arranged and conducted, it was almost a foregone conclusion that the would-be saboteurs would be found guilty and receive the death penalty. Their confessions and the discovery of the crates of explosives brought from Germany to destroy and disrupt American war production--all documented by the press--certainly insured a wide-spread belief in their criminality days before the trial began. Nevertheless the defense counsels for both Dasch and the other seven defendants did their best to counter the charges levied by the prosecution.

Colonel Ristine's defense of Dasch was based primarily on Dasch's voluntary confession and cooperation with the FBI. Colonels Royall and Dowell stressed the fact that their clients had committed no acts of sabotage and tried to establish that they had had no intention of carrying out the mission entrusted to them by the German Abwehr. Royall also questioned the validity of the military commission formed by President Roosevelt, which in essence suspended the writ of habeas corpus and denied the eight men a trial by civil 
court. Royall maintained that the crimes with which the saboteurs were charged were covered by civil statutes, and thus the men were due a trial in civil court. That they were not so tried effected a challenge to both their civil rights and the American Constitution.

Royall informed the President, the military commission, and the prosecution of his intention to apply for writs of habeas corpus and to test the legality of the military trial and the President's war powers in forming the military tribunal. Royall was well aware that his appointment had been made by the same authority that created the military commission, yet he felt he could not compromise in the defense of the Germans over a procedure which he felt was legally questionable. Royall wanted the president to grant either him and Dowell, or other individuals, the authority to pursue the matter as far as it could go. (44)

The President was noncommittal. It was relayed via the President's secretary that Royall and Dowell would have to make their own decisions as to the scope of their authority.(45) Royall and Dowell responded:

We...are of the opinion that we are authorized, and our duty requires us, first, to try to arrange for civil counsel to institute the proceedings necessary... and second, if such arrangements cannot be made, to institute such proceedings at the appropriate time. Unless ordered otherwise, we will act accordingly. (46)

It was Royall's hope to convince the United States Supreme court to convene in special session to receive requests for a writ of habeas corpus, which if granted, 
would put the saboteurs under the jurisdiction of the civil courts. The foundation for Royall's request was in the Supreme Court decision of 1866 in "Ex parte Milligan," which ruled that a civilian could not be tried by a military commission unless martial law had been declared, or the civil courts were not in operation. (47) Milligan, a resident of Indiana during the Civil War, was accused of conspiring against the United States. His activities considered dangerous to the North were: inciting to insurrection; communicating with the enemy; giving aid and comfort to the enemy; conspiring to seize munitions of war and to free prisoners of war; and resisting the draft. Milligan was tried before a military court established under the authority of President Lincoln after he had suspended the writ of habeas corpus. Though convicted, Milligan was awarded a writ of habeas corpus by the supreme court and a trial in civil court. (48) In the Milligan case, the Supreme Court held that neither the President nor Congress had the power to set up military tribunals except in the actual theater of war where the civil courts were no longer functioning. (49) It was Royall's argument that American justice and legal rights applied to the German saboteurs--agents of an enemy in time of war--as much as to any American citizen.

The court agreed to meet on July 29, and Royall made his formal application for writs of habeas corpus on July 28 to the District Court in Washington, D.C., since the Supreme 
Court would only hear the case on appeal from a lower court. Colonel Ristine did not feel that Dasch would benefit from an appeal to the supreme court and declined to join in the appeal, therefore escaping the adverse publicity and personal attacks visited upon Royall and Dowell.

One letter to Royall implied threats of violence and suggested that Royall stay out of his home state of North Carolina after the war.(50) One woman wrote that the appeal to the supreme court on behalf of the saboteurs made a mockery of the United States, but added: "It is one way to kill Hitler. He must be dying of laughter right now."(51) A milder reprimand came from The New Republic, which stated:

Even in wartime and even toward the enemy we do not abandon our basic protection of individual rights. Where should America show its greatest strength? In assuming every possible legal recourse to the enemy or striking at the heart of the enemy's power and destroying him? The legal tradition will not win the war for the United States. (52)

The New York Times wrote:

The decision to seek recourse in the supreme court did not meet popular approval in washington. On the contrary there is great dissatisfaction here with the length to which the trial has already proceeded. Complainants recognize the duty of the Army Colonels to demand all possible rights for the saboteurs but none the less there was a feeling of disappointment that further steps would be taken on their behalf. On all sides hope was expressed that the Supreme Court would make short work of the move. (53)

Royall also received positive reinforcement for his efforts to insure that the seven saboteurs received the justice he felt they deserved under the Constitution. His 
desire to test the legality of the military trial and his efforts on behalf of his clients undoubtedly had much to do with the Court's decision to meet in special session. Royall's case was a test of the principles of American justice, and there was a great deal of interest among the justices and ordinary citizens as to how the case would be argued.

In his case before the Supreme Court, Royall based his defense on the same argument as he had used before the military commission: that though they had the equipment to do so, the seven men committed no act of sabotage in the United States. He went on to stress that neither the coast of Long Island or Florida could be construed as a zone of military operations, and that only congress had the right to suspend the writ of habeas corpus, and then only in case of rebellion or invasion.(54) Most important of all, Royall emphasized the precedent established in "Ex parte Milligan," which stated:

Martial law cannot arise from a threatened invasion. The necessity must be actual and present; the invasion real, such as effectually closes the courts and deposes the civil administration. (55)

For Royall's case to be successful, he had to convince the Supreme Court that the trial of the saboteurs was illegal under the Constitution, that the President of the United States had gone beyond his legal powers in forming the military commission, and that the crimes the men were charged with came under civil statutes. 
Despite his ingenious defense, Royall was questioned by the Supreme court and challenged by Attorney General Biddle over the definition of the location of a theater of wartime operations. Justice Frankfurter asked: "Cannot the enemy determine what the theater of operations is by being the aggressor?" (56)

As prosecutor, Biddle maintained that the entire east coast of the United States was a theater of operations, and cited the sinking of merchant ships off the coast and the landing of the German saboteurs as proof. The fact that Nazi Germany and the United States were at war was conclusive enough for Biddle that the arrival of the saboteurs was an act of invasion and should be treated as such. "Ex parte Milligan" did not pertain to the case, according to Biddle, since Milligan, as opposed to the saboteurs, never wore an enemy uniform, nor was he a resident of a state in rebellion during the Civil war. For Biddle, the major issue before the Supreme court was whether or not the President had acted legally in causing the eight Germans to be tried by a military court. He felt the President was perfectly within his rights as Commander-in-Chief to give up the eight men to a military trial, and cited as precedent a law passed by Congress in 1798, which stated:

Whenever there is a declared war and the President makes a public proclamation of the event, all natives, citizens, denizens or subjects of the hostile nation...shall be liable to be apprehended, restrained, secured and removed as alien 
enemies. (57)

Biddle felt the authority of the president included the power to bar these enemy aliens from the civil courts. In fact, Biddle indicated his belief that the court should consider repealing that part of "Ex parte Milligan," which stated that military commissions could not be established for civilians unless martial law had been declared or the civil courts were not functioning. He felt the case interfered with "...the appropriate execution of orders of the Commander-in-Chief." (58)

Biddle's concluding remarks accurately summed up his own feelings and the position of the administration:

The United States and Nazi Germany are fighting a war to determine which of the two shall survive. This case is no more important than a small skirmish, but on an important front. It is part of the business of war. Military trial for the petitioners endangers no traditional civil liberty. These German soldiers have already been given rights which no American would receive in Germany, and now ask for Constitutional privileges which we do not allow our own soldiers.(59)

The hearing before the supreme court lasted just two days. On Friday, July 31, the decision was read without the usual accompanying opinion which, in the interest of time, would come later. The court unanimously decided that the crimes with which the saboteurs were charged were sufficient cause for the President to authorize their trial by military commission. (60) Therefore, President Roosevelt's military tribunal was legal under the Constitution, and the plea for writs of habeas corpus for the seven men were denied. 
It was not until October 29, 1942, that the full opinion of "Ex parte Quirin" was released. In it the Supreme court affirmed the right of the President to have appointed a military commission to try the saboteurs, because the eight men were examples of "unlawful combatants" as opposed to "lawful combatants." "Lawful combatants" would have worn uniforms and would have been held as prisoners-of-war. (61) Since the saboteurs had worn civilian clothes and had come "with hostile purpose"--that is with crates of explosives--across the battleground of the Atlantic and the boundaries of America, Royall's defense that the men had committed no act of sabotage was not accepted by the court.(62) To the court, the demeanor and furtive methods of the saboteurs bespoke their belligerence and guilt.

After the Supreme Court's decision, there was little doubt as to what the outcome of the military trial would be. Yet, even through his closing statement, Royall continued to emphasize what he had throughout his defense: that the men had not committed any act of sabotage, and it was doubtful that they would have. For Kerling, Quirin, Thiel, Neubauer, and Heinck, Royall probably expected a guilty verdict, but hoped for a prison term. In the case of Herbert Haupt, Royall stressed Haupt's youth and the circumstances under which he had left the United States. Haupt had not purposefully left the United States for Germany, but had gone to Mexico after learning of his girlfriend's pregnancy. 
Royall stated that working with walter Kappe and the Abwehr was merely Haupt's way of getting back to America.(63)

Peter Burger probably made the best impression of the eight at the trial due primarily to the manner in which he conducted himself and answered questions. Royall felt that Peter Burger deserved leniency because of his appearance as a witness for the prosecution. (64) The fact that he had been arrested by the Gestapo also struck a responsive chord with those before whom he testified because it made him appear to be a dissident of the Third Reich. Royall used the anti-Nazi attitude attributed to Burger as the reason behind Burger's desire to leave Germany in any way opportunity provided.

Ristine's closing summary on the behalf of George Dasch reiterated Dasch's aid to the FBI and the part he played in the arrest of the other seven saboteurs. Ristine sought an acquittal on all the charges, and in a different year, Dasch might have received both the acquittal and the hero's accolades he felt he deserved. But in 1942, the appearance of eight German saboteurs in a nation at war decreed otherwise. In the era of the "total" war, the United States could not afford to be tolerant of its enemies, nor would the country allow it. Roosevelt's selection of the military commission, its method and secrecy were all part of a process to insure that all eight men received the death penalty.

The trial ended on Saturday, August 1, and on Monday, 
August 3 , the military commission reached a verdict and reconvened to inform the prosecution, defense, and the prisoners, not what the verdict was, but only that one had been reached. This same style of secrecy had been maintained throughout the trial; in fact the trial transcript remained a classified government document until 1960. It was up to President Roosevelt to consider the commission's recommendations and decide the final verdict. The defendants were not allowed the right of appeal.

On Saturday, August 8, 1942, Edward Kerling, Heinrich Heinck, Richard Quirin, Werner Thiel, Herbert Haupt, and Hermann Neubauer were electrocuted in the Washington, D.C. jail. It was only after their death that the nation learned of the military commission's findings and President Roosevelt's verdict. All eight saboteurs were found guilty and sentenced to death. However, the commission recommended a commutation of sentence for George Dasch and Peter Burger because of their cooperation as government witnesses. Burger was sentenced to life imprisonment, and Dasch received thirty years. (65)

After the executions, there were associated trials of those whom the government accused of helping the eight saboteurs. Herbert Haupt's parents and his aunt and uncle were tried for treason in Chicago, along with the parents of Wolfgang Wergin, the friend with whom Haupt had originally left the United States. Peter Burger testified against them as the government's major witness. All were found guilty, 
the men sentenced to death, the women to twenty-five years and $\$ 10,000$ fines. However, after appeals the women were found not guilty, wergin and Froehling received five years, and Haupt was sentenced to life imprisonment and a $\$ 10,000$ fine. (66)

In New York, Burger also testified against Anthony Cramer, to whom Thiel had given his money belt for safe keeping. Cramer was sentenced to forty-five years, but appealed all the way to the Supreme court where the verdict was overruled. Cramer was finally sentenced to six years for trading with the enemy. Hermann Faje had taken Heinrich Heinck's money and received five years for trading with the enemy. Edward Kerling's girlfriend, Hedwig Engemann, and Helmut Leiner, whom Kerling had contacted as a reliable source of help, were both convicted of concealing their knowledge of the saboteurs in America. Engemann received three years and Leiner was sentenced to eighteen, but was paroled in $1954 .(67)$

George Dasch and Peter Burger served only a fraction of their respective prison terms. In April, 1948, President Truman commuted their sentences and the two men were deported to Germany. (68) Presumably by 1948 the crimes for which Burger and Dasch had been convicted were not taken as seriously as they had been in 1942. Certainly immediately after the saboteurs were caught, public opinion raged against them, demanding death as the only fitting punishment. After the arrest of the eight saboteurs and the 
execution of six of their number, sabotage in America became something to guard against with increasing vigilance. The public was warned that "...the Germans will try again--next time perhaps not by a landing on our coasts but by some new route!"(69) "Patriotic citizens" were encouraged to take "defensive counterespionage" measures in their speech and written communications and in the overall conduct of their daily lives to aid in the struggle against enemy agents. (70) But by this time, the United States was more prepared to battle the total war strategy practiced by the enemy. The Nazis were still consistently portrayed as brutal evildoers, but fifth columnists, saboteurs, and spies were acknowledged with less of a shock then they had been in the Abwehr's early days in America. And perhaps most importantly, in late 1942, the initiative was just beginning to pass to America and its allies. Americans were dealing with a more positive vein of war news following the execution of the six German agents and the internment of Dasch and Burger than they had when the arrests were first made public. But, if the United States and its allies had experienced severe and consistent losses throughout most of the war, it is probable that Dasch and Burger would either have been executed or would have stayed in prison much longer.

By 1948, when Dasch and Burger were released, attitudes toward who the foe was had changed. The country was deeply involved in the Cold war and concerned over the 
containment of Soviet expansion. In 1942, the eight saboteurs had been "the enemy." In 1948, Burger and Dasch were merely extra baggage left over from an incident that had lost much of its significance; who were remembered only to be released, deported, and forgotten.

The Abwehr learned of the dissolution of Operation Pastorius when J. Edgar Hoover announced the arrests of the eight German agents. General Lahousen, the head of the Abwehr's sabotage division wrote:

...we have been receiving Reuter reports of American radio transmission announcing the arrest of all participants in Operation Pastorius, some in New York and some in Chicago. The reports give the correct location of the landings in the United States and of the targets for the planned sabotage operations. (71)

The failure of Operation Pastorius, coming no more than a year after the Abwehr had suffered the humiliating Sebold affair, hurt the status of the Abwehr in Germany. The inefficiency of Admiral Canaris' intelligence organization had become more apparent, and it was clear it had blundered particularly in its choice of agents.

In 1941, William Sebold had double-crossed the Abwehr and an entire network was uncovered by the FBI. Now a year later the Abwehr had been stung by treachery again, this time in the person of George Dasch, who ambitiously sought to emulate Sebold's actions. Unfortunately for Canaris and his service, the United States was not the only site of Abwehr failures. Within the Abwehr's files were a number of code-name missions which, like Pastorius, were unsuccessful. 
Operation "Weisdorn" was to be an incitement of a popular uprising in South Africa; Operation "Tiger" the incitement of Afghanistan and western India against the British; Operation "Shamyl" the instigation of an anti-soviet revolt in the Caucasus--none of which proved triumphant for the Abwehr.(72) Instead, the miscarriage of these missions bespoke Abwehr incompetence and in the long run, a marked inability to get the job done right.

Though the Abwehr's chief antagonist, Reinhard Heydrich, had been assassinated in Czechoslovakia and had died on June 4, 1942, both the Abwehr and Canaris had no lack of critics or enemies. The Abwehr had undergone severe cuts to its authority when, prior to Heydrich's death, he and Canaris signed an agreement which increased the powers of the RSHA at the expense of the Abwehr. In March, 1942, the RSHA took over all political intelligence services abroad and part of the Abwehr's counterespionage field. (73) In addition to this loss of power and its failures abroad, the Abwehr was unable to meet the general staff's demands for more information concerning the enemy's battle plans, especially in the Russian and North African campaigns. (74) Abwehr intelligence forwarded to the Foreign Armies Sections for final evaluation was often received critically. (75) Consequently the general staff evaluators believed they could do a better job than the Abwehr in gathering and appraising information pertaining to the enemy, and as a result began taking over some of the Abwehr's sources of 
information, among them the Abwehr's Main Post East, codenamed "Walli I."(76)

The Abwehr had other problems that hampered its attempt to stay afloat and functioning in the Third Reich. Before his death, Heydrich had indicated to Hitler and Himmler apparent ties the Abwehr seemed to have with the anti-Nazi resistance. (77) The Abwehr had played host to a number of opponents to the Nazi regime, providing them with an ideal cover. Among these were Hans Oster, head of the Abwehr's "Zentralgruppe," and Helmut Groscurth, the head of Abwehr II until 1939. Both of these men were part of the military's plan--headed by Chief of the General. Staff Franz Halder--to overthrow Hitler during the Czechoslovakian crisis in 1938; a proposed coup to which Admiral Canaris was evidently receptive. $(78)$

Though Canaris rededicated himself to the regime following Hitler's success at the Munich Conference, he joined in the planning of another "coup d'etat" in late 1939. This coup was organized primarily to eliminate Hitler and thereby avoid mounting an offensive in the west, an attack which Canaris and others felt would sever important ties with Western Europe and bind Germany closer to Russia. (79) The circle had enlarged and included not only General Halder, but the man whom he had replaced, Ludwig Beck. Oster's circle also included the ex-mayor of Leipzig, Carl Goedeler, and "Reichsgerichtsrat" Hans von Dohnanyi, a high official in the judiciary who manned desk "ZB"--Foreign 
Policy Reports--in Oster's department, and maintained contact with the Christian resistance circles through his brother-in-law, Pastor Dietrich Bonhoeffer. (80)

The coup failed to materialize and the offensive against western Europe took place. This aborted coup marked the end of Admiral Canaris' active participation with the resistance, though he was undoubtedly conscious of resistance plans and intrigue within the oster circle.(81) By March of 1942, Oster was busy again with renewed plans for a "coup d'etat" along with retired General Beck and officers from Army Group Center in Russia, including Fabian von Schlabrendorff and Colonel Henning von Tresckow. This group fomented the tactical plan that the July 20, 1944, assassination attempt on Hitler was to follow. (82)

The strong indications that the Abwehr was infested with "traitors" lent credence and power to those who would see the Abwehr dissolved or put under a different department. The specter of conspiracy in the Abwehr, coupled with what many saw as its declining effectiveness, simply added to already strong criticism against canaris and his entire organization. If the Abwehr had to deal with the competition and intrigue instigated by its rivals, and the political dissension and lack of internal cohesion within its own ranks, how effective could their performance in the intelligence war have been? Put in this light, the vain attempt to install German saboteurs in America in June, 1942, was a crucial failure to the Abwehr and its existence 
under Admiral Canaris, and had a great deal of influence on future Abwehr actions in the United States.

In his book, They Came To Kill, Eugene Rachlis said of Operation Pastorius:

At the time it was conceived, the plan was logical in terms of the Nazis' military superiority in Europe. But not long after the failure of the saboteurs, Hitler and the German High Command had to contend with major defeats in Russia and Africa. It is not likely that any new plans from Abwehr II, even had they been suggested, would have received high priority. (83)

Rachlis could have easily added that the Abwehr's institutional health and loyalty were so faulty and questionable that chances are, it could not have successfully mounted any sort of sabotage operation, nor would it have been asked. The controversial status of the Abwehr, following Operation Pastorius, had much to do with the subsequent lack of Abwehr-inspired offensives in America. Admiral Canaris and his organization never again mounted a sabotage operation of this size against the United States. 
1. Eugene Rachlis, They Came To Kill (New York, 1961), 10-11, 13; Wighton and Peis, Hitler's Spies and Saboteurs, 41-43.

2. Blaney Matthews, The Specter of Sabotage (Los Angeles, California, 1941), 7-8.

3. Ibid., 35-36.

4. Rachlis, They Came to Kill, 18-19; Federal Bureau of Investigation, "Re: George John Dasch, with aliases, et al Sabotage" (Washington, D.C., November 14, $1942), 2$.

5. FBI, "George John Dasch," 2 .

6. Wighton and Peis, Hitler's Spies and Saboteurs, 50; Farago, Game of Foxes, $5 \overline{49}$.

7. FBI, "George John Dasch," 3; Rachlis, They Came to Kill, $48-50$.

8. Wighton and Peis, Hitler's Spies and Saboteurs, 47; Rachlis, They Came to Kill, 51-52, 76-77; FBI, "George John Dasch," 3 .

9. Wighton and Peis, Hitler's Spies and Saboteurs, 49; FBI, "George John Dasch," 3 .

10. FBI, "George John Dasch," 8.

11. Ibid., 8; Rachlis, They Came to Kill, 26

12. Kahn, Hitler's Spies, 55, 162.

13. FBI, "George John Dasch," 14.

14. Ibid., 14; Hynd, Passport to Treason, 35-36; Rachlis, They Came to Kill, 37-39.

15. Rachlis, They Came to Kill, 39.

16. Ibid., 42; FBI, "George John Dasch," 15.

17. Rachlis, They Came to Kill, 55; FBI, "George John Dasch," 8-9. 
18. Wighton and Peis, Hitler's Spies and Saboteurs, 45; FBI, "George John Dasch," 9; Rachlis, They Came to Kill, 56-57.

19. FBI, "George John Dasch," 9-11; Rachlis, They Came to Kill, 68-70.

20. Wighton and Peis, Hitler's Spies and Saboteurs, 46, 51; Rachlis, They Came to Kill, 59.

21. FBI, "George John Dasch," 14; Wighton and Peis, Hitler's Spies and Saboteurs, 46-47.

22. Rachlis, They Came to Kill, 63 .

23. FBI, "George John Dasch," 13.

24. Ibid., 13.

25. Ibid., 12 .

26. Rachlis, They Came to Kill, 71-72.

27. Ibid., 81-82; FBI, "George John Dasch," 4.

28. Rachlis, They Came to Kill, 72.

29. FBI, "George John Dasch," 4.

30. Wighton and Peis, Hitler's Spies and Saboteurs, 49 ; Rachlis, They Came to Kill, 73 .

31. Rachlis, They Came to Kill, 21; FBI, "George John Dasch," 6-7.

32. Sayers and Kahn, Sabotage, 123-124; Rachlis, They Came to Kill, 20; FBI, "George John Dasch," 6-7.

33. FBI, "George John Dasch," 5-6; Rachlis, They Came to Kill, 99-103, 106-108; New York Times (July 16, 1942), $1: 6$.

34. Rachlis, They Came to Kill, 151; FBI, "George John Dasch," 8; Wighton and Peis, Hitler's Spies and Saboteurs, 58 ; New York Times (July 16, 1942), 1:6.

35. Wighton and Peis, Hitler's Spies and Saboteurs, 58; Rachlis, They Came to Kill, 151, 153 .

36. Rachlis, They Came to Kill, 143; Wighton and Peis, Hitler's Spies and Saboteurs, 62 . 
37. Rachlis, They Came to Kill, 144 .

38. Ibid., 145.

39. Ibid., 162 .

40. Wighton and Peis, Hitler's Spies and Saboteurs, 75 .

41. FBI, "George John Dasch."

42. "The 8 Nazi Saboteurs Should Be Put To Death," Life, XIII.2:32-33 (July 13, 1942).

43. Rachlis, They Came to Kill, 188-189.

44. Ibid., 182 .

45. Ibid., 182 .

46. Ibid., 182 .

47. Ibid., 241.

48. Ibid., 254-255.

49. New York Times (July 28, 1942), 10:4.

50. Rachlis, They Came to Kill, 250.

51. Ibid., 250 .

52. "The Saboteurs and the Court," New Republic, CVII.6:159-160 (August 10, 1942).

53. New York Times (July 28, 1942), 10:3.

54. Rachlis, They Came to Kill, 256.

55. Ibid., 257.

56. Ibid., 259 .

57. Ibid., 264 .

58. Ibid., 265 .

59. New York Times (July 29, 1942), 11:4.

60. Rachlis, They Came to Kill, 272 .

61. Ibid., 294 . 
62. Ibid., 294-295.

63. Ibid., 276.

64. Ibid., 277.

65. Ibid., 287-288.

66. Ibid., 292.

67. Ibid., 293.

68. Ibid., 299; FBI, "George John Dasch," 16; Wighton and Peis, Hitler's Spies and Saboteurs, 79.

69. Irwin, what You Should know, 177.

70. Ibid., 209-213. 75.

71. Wighton and Peis, Hitler's Spies and Saboteurs,

72. Höhne, Canaris, 491.

73. Ibid., 470-471.

74. Ibid., 467, 490; Kahn, Hitler's Spies, 363.

75. Höhne, Canaris, 467.

76. Ibid., 467; Kahn, Hitler's Spies, 430; Reinhard Gehlen, The Service: The Memoirs of General Reinhard Gehlen, trans. David Irving (New York, 1972), 41. Service, 28 .

77. Kahn, Hitler's Spies, 267; Gehlen, The

78. Höhne, Canaris, 303; Anthony Cave Brown, Bodyguard of Lies (New York, 1975), 166.

79. Höhne, Canaris, 383; Cave Brown, Bodyguard of Lies, $179-180$.

80. Höhne, Canaris, 287, 383-384.

81. Ibid., 422 .

82. Ibid., 495-496.

83. Rachlis, They Came to Kill, 302 . 


\section{CHAPTER VII}

\section{THE FINAL REMNANT}

The collapse of the Abwehr's large spy networks in the summer of 1941 came at a time when the Abwehr was greatly in need of information from America. Just a few months after the arrest of the Ludwig and Duquesne rings, the Japanese attacked Pearl Harbor and the United States was propelled into what had become another world war. The number of Abwehr agents who had operated up through the summer of 1941 was sharply reduced. The FBI had arrested large numbers of spies, and only a few escaped the net and continued to operate. Among these was Simon Emil Koedel, who weathered America's spy scares and worked for Germany from 1936 until $1944 .(1)$

Koedel was older than the majority of Abwehr spies, a few days short of his sixty-third birthday at the time of his arrest. Koedel was born in Bavaria in 1881 and came to the United States in 1904. He served in the United States Army from 1908 to 1911, and after his discharge became a naturalized American citizen.(2)

Ladislas Farago, author of The Game of Foxes, called Koedel "...the best all-round spy the Abwehr had in the United States--in two world wars."(3) Farago wrote that Koedel began his spying in America when the First World War 
began by watching and reporting on ships and harbor activities. He went to England to collect military intelligence, but was arrested and deported back to the United States. Farago claimed Koedel "somehow" reached Germany, obtained the rank of Captain and worked in intelligence. When Hitler took over, Koedel joined his "...new crop of intelligence officers," all the time holding on to his American citizenship. (4)

The FBI report on Koedel agreed that he was involved in some sort of espionage work during World War I, but intimated that it was only in Britain and not the United States. According to the FBI report, Koedel had to have been back in the United States shortly after the war, since a three-year-old daughter was adopted in 1921 by Koedel and his American-born wife. The FBI also stated that Koedel became a motion picture projectionist and operated his own theater. In 1933, Koedel divorced his first wife and remarried. (5) The information from the Bureau seems to suggest that Koedel remained in the United States following his deportation from Great Britain.

Sources agree however, that it was sometime in the middle thirties that Koedel volunteered his services to "Abwehrnebenstelle" Bremen to act as a spy against the United States.(6) Though Koedel had retained his American citizenship, he stated: "I love Germany with all my heart and I am even willing...to give my very life for her."(7) Koedel was trained by spymasters at the Bremen subpost and 
returned to America as a "sleeper" agent. He established a residence in Manhattan, and on a monthly salary of $\$ 200 \mathrm{a}$ month plus expenses, explored and consolidated intelligence resources he would use on behalf of the Abwehr. (8)

To obtain intelligence in the United States, Koedel adopted a technique that appeared to be free from evasiveness and therefore was rarely questioned. Koedel applied for membership in the American Ordnance Association, a pro-defense organization comprised of armaments and munitions producers who maintained close ties to the war Department. Koedel enclosed his discharge papers and identified himself as a "...chemical engineer with large stock holdings in major defense industries...."(9) He was accepted in the $A O A$ and put on the War Department's confidential mailing list for all information regarding military supplies and production. As a member of the AOA, Koedel was given access to all meetings and lectures of the Association, and was allowed admittance to any defense plant in the United States.(10)

Koedel used the stationery of the AOA to write letters to the chairmen and members of the Military and Naval Affairs committees in both houses of congress, in which he called himself "an investor with considerable stake in the American defense industry," and asked for their help "in the interest of our nation's preparedness and security."(11) Senator Robert Reynolds of North Carolina, a member and later the chairman of the Senate's Military Affairs 
committee, replied and invited koedel to visit him in Washington. (12) Koedel was able to use this relationship to his advantage later in his career when he needed a highly-placed friend.

After Germany's invasion of Poland, Koedel was activated as an operational agent of the Abwehr. He used his twenty-one-year-old adopted daughter, Marie, to help him spy on the New York harbor and its shipping. Koedel had his daughter spend time with sailors and merchant seamen on the docks and accompany them to waterfront bars, where she would attempt to gain information on convoys and cargoes leaving the United States. Marie's duties included a daily ride on the Staten Island ferry from which she could observe ships in the harbor and what they were loading or unloading. She also typed reports for Koedel which relayed the intelligence they had obtained to the Abwehr.(13) To augment what Marie discovered, Koedel sometimes dressed in the clothes of a longshoreman and visited docks along the waterfront to watch ships being loaded. The name and address of the manufacturer listed on the crates of supplies often gave Koedel the clues he needed to conclude what kinds of materials the ships were carrying.(14)

Koedel preferred to let his daughter handle the waterfront while he occupied himself with the more interesting aspects of procuring intelligence. In December, 1939, Koedel managed to gain entrance to the United States Army's Chemical Warfare Center at the Edgewood Arsenal in 
Bel Air, Maryland. Twice in November, Koedel had tried to get into Edgewood by showing his AOA card, but was turned away. He finally telephoned the AOA in washington, which called the war Department, which in turn called the Edgewood Arsenal. Koedel was given a guided tour on December 7, 1939, a description of which he promptly sent to Bremen. (15) His report included as much technical data as he could assimilate, information on the storage facilities, and even names of the arsenal's suppliers. He also sent labels he peeled off boxes ready for shipment, one of which read: "25 Hand Grenades--Irritant M 7--Fuse M 200--Gas."(16)

Koedel had planned well when he first wrote to Senator Reynolds under the auspices of the AOA. In March of 1940, the German General Staff was planning its invasion of France and needed information on the French ports of Nantes and La Rochelle, particularly whether these ports could hande ships other than colliers and tankers. Koedel contacted Senator Reynolds and said he needed the information to arrange for supply shipments to France. Thanks to the Senator, Koedel was able to report to Bremen that, "according to the U.S. Maritime Commission, these ports are not limited in their facilities, but are capable of handing ships loading oil and coal, as well as general cargo."(17) As an additional favor, Senator Reynolds put Koedel on the list to receive a confidential report issued weekly by the Munitions Board of the State Department, which listed permits granted for the export of war material to Great 
Britain. (18)

Koedel made use of Senator Reynolds again in August, 1940, when the Abwehr asked him to obtain the passenger list of the army transport, "American Legion," which had left Finland bound for New York. The transport had evidently made an unscheduled stop in Scotland, and the Abwehr wanted to find out what passengers boarded there. Koedel asked Reynolds, who wrote to the State Department and the War Department, and asked that his Military Affairs Committee receive the passenger list. The war Department would not release the list, but when Reynolds insisted, it was finally relinquished to him. It is not clear what koedel told the Senator that resulted in Koedel's knowledge of the transport's passengers, but in December, 1940, Koedel was able to report to the Abwehr that the "American Legion" had picked up no passengers in Scotland. (19)

Marie's success on the waterfront was used by Koedel to augment the information he sent to the Abwehr. Through the sailors and merchantmen she dated, Marie was able to provide Koedel with enough intelligence to write two reports for the German Navy. The first was entitled: "Report Concerning American Ships Inspected by England on Suspicion of Contraband." The second: "Report on the Conduct of Enemy Ships in Convoy at Sea in the Atlantic, Based on Conversations with British Seamen."(20) The second report was assembled with the help of Duncan Scott-Ford, a British sailor who had jumped ship in New York and was picked up by 
Marie Koedel. Scott-Ford evidently volunteered himself as a spy for the Abwehr, and was highly recommended by Simon Koedel. This former British sailor went to work in Lisbon, where his knowledge of British convoy routes made him a welcome addition to the Abwehr's shipping expert in Portugal. Scott-Ford was hanged by the British in November, $1942 .(21)$

The reason Simon Koedel was able to operate for so long in the United States, and why he was able to escape the purge of Abwehr agents precipitated by the FBI plant, William sebold, was singularly simple: Koedel did not use a radio to send his intelligence to Germany. Officers of the Bremen subpost had not allowed their agents to send intelligence through "Tramp." Thus Koedel was not involved with Sebold's radio or the communications center of Axel Wheeler-Hill, both of which were compromised because of Sebold's involvement with the FBI.

For convoy and shipping intelligence that needed quick transfer to Germany, Koedel used the cable facilities and the Enigma coding machine of the German Consulate in New York. (22) All other intelligence obtained by Koedel went through the mail, and was thus subject to the scrutiny of British censors, who in the past, had uncovered Guenther Rumrich and Kurt Ludwig. To thwart the censors, Koedel made use of his $A O A$ affiliations by using the same envelopes the War Department sent to AOA members. Apparently Koedel adapted these envelopes to send his intelligence to the 
Abwehr via a mail drop in Milan, correctly assuming that the censors would not suspect the official-looking government envelopes. (23)

The espionage career of Simon Koedel eventually came to an end. From 1935 to 1943, Koedel worked as a projectionist at the Lyric Theater in New York City. Evidently his co-workers entertained suspicions because of letters bearing foreign addresses Koedel brought with him to the projectionist's booth. Apparently Koedel received communications from Germany and from other Abwehr agents and hid them in an old stairway at the theater. Additional doubts about koedel grew among his fellow employees when a section of film about a new airplane was cut from a newsreel. A search of the projectionist's booth revealed nothing. The missing film was later found by Koedel while working alone in the booth; a discovery the FBI thought "...made it appear that it had actually been in his possession." (24)

In 1943, Koedel left New York for Harper's Ferry, Virginia, where he found work as a projectionist. It is not known whether his daughter continued her espionage activities on the New York waterfront, though chances are she did not. Koedel was reportedly a tough man to work for, in addition to being a stern father and a severe disciplinarian. He often hit Marie or beat her with his belt if he felt she was lazy or slow in performing her duties. (25) Koedel's attitude toward his daughter was not 
one to induce love and affection, nor did it insure filial loyalty. Thus, unfortunately for Simon Koedel, Marie told all to a boyfriend who told a friend who eventually went to the FBI. Koedel was arrested on October 23, 1944, in Harper's Ferry. Marie was arrested later that same day. (26)

Simon and Marie Koedel were indicted for conspiracy to violate the Peacetime Espionage Statute. Apparently the FBI accused them of spying for the enemy only from 1939 to 1941 , either not knowing about or ignoring their activities in other years. Consequently, even though they were arrested in wartime, their espionage work came under peacetime regulations. (27) There was no threat of the death penalty for the Koedels, and Simon was not about to fill anyone in on what they had been doing since October, 1941, nor was he anxious for the FBI to find out about the more than six hunàred messages he successfully sent to the Abwehr. (28) Thus, Koedel was quick to plead guilty after the trial began on February 7, 1945. Marie Koedel was found guilty by a jury on February 19. They were both sentenced on March 1, 1945, Marie to seven years and six months and her father to fifteen years. (29)

Though Koedel was arrested and sentenced to serve a prison term, he fared better than the Abwehr which had fostered and subsidized his espionage activity. The numerous failures attributed to the Abwehr were paraded before Hitler by his henchmen, and by late 1943, the Abwehr's incompetence was a common theme when Hitler 
discussed Canaris and his organization. (30) In January, 1944, a series of events turned the tides of fate permanently against Admiral Canaris and the Abwehr.

On January 12, 1944, the members of an anti-Hitler group called the Solf circle were arrested by the Gestapo. Among those taken in was Major Otto Kiep of the Ausland branch of the Abwehr. (31)

In late January, 1944, the German Army commanders were anxious about an Allied landing behind German lines and were particularly interested in what the Abwehr knew about enemy plans. When Admiral Canaris visited the headquarters of the Commander-in-Chief Southwest, on January 21, 1944, he stated that the Abwehr contemplated no Allied landing in the near future. Just hours later the Allies landed at Anzio, fifty miles behind German lines.(32) Needless to say, this did little to enhance the reputation of Canaris or the Abwehr. Finally on January 27, 1944, Dr. Erich Vermehren, a member of the "Abwehrstelle" in Istanbul, and his wife, defected to the British. (33)

It was this last incident that broke the proverbial camel's back for Canaris and the Abwehr. On February 11, 1944, Wilhelm Canaris was relieved as head of the Abwehr. The following day a directive was issued from the Führer's headquarters which stated that a unified German intelligence service was to be formed under the command of Heinrich Himmler. As an independent organization, the Abwehr was finished. (34) 
The head of Abwehr I, Colonel Georg Hansen, who had taken over from Piekenbrock in 1943, was put in charge of the Abwehr during reorganization. Canaris' name was taken off the active list and he was directed to Burg Lauenstein in Thuringia under what was essentially house arrest. However, by the end of June, 1944, Canaris was again made available for duty and Hitler appointed him head of the OKW's special staff for mercantile warfare and economic combat measures. (35)

Canaris had little time to enjoy his new appointment. On July 20, 1944, Colonel Count Claus Schenk von Stauffenberg arrived at the Führer's headquarters in East Prussia to attend the daily conference. The bomb he carried in his briefcase failed to kill Hitler, and nearly 5000 people were executed and some 7000 arrested by the Gestapo as a result of the failed assassination attempt. (36)

Canaris knew of the plot, but did not take part. He did not get along personally with Staufenberg and disapproved of what he felt were the leftist leanings and amateur conduct of some stauffenberg group members. For their part, the July 20 plotters found Canaris too conservative and of little importance to be actively involved or informed. (37) Canaris did not even know the date of the portended military coup. When he received the call on the afternoon of July 20 , informing him of Hitler's supposed death, Canaris' first response was, "Dead? Good God, who did it--the Russians?" (38) However, Canaris was 
arrested on July 23, after being implicated by Abwehr I's Colonel Hansen, who had actively conspired with stauffenberg and others in the military coup.

Further interrogations and confessions vaguely linked Canaris to the resistance, particularly to the oster group. What tied Canaris inexorably to the anti-Nazis was the discovery of the Oster circle's papers on September 22 , 1944, which were hidden at the Abwehr's wartime headquarters at Camp Zeppelin in Zossen on the outskirts of Berlin. (39) These papers evidenced that the conspiracy against Hitler had begun long before the war; some of the material dated from as early as 1938, when a military coup was first contemplated. (40) The zossen papers, indiscreetly preserved by Hans von Dohnanyi, were exposed by the Gestapo. This proved disastrous for a number of Abwehr and military officers who had contributed their ideas and names to the resistance against Hitler. The papers were the proof long sought by the Gestapo of Canaris' "treachery" and effectively sealed his fate.

Thus by October, 1944, when Simon Koedel was arrested, the Abwehr he knew had been abolished. June 1, 1944, was the official date of dissolution for the Abwehr. Abwehr I and II were consolidated to form a separate Military Department--or "Amt Mil" in its abbreviated form--and transferred to the RSHA. Georg Hansen, the former head of Abwehr I, was placed in charge of "Amt Mil." After Hansen's arrest, SS General Walter Schellenberg who headed RSHA VI, 
the Nazi Party's foreign intelligence organ, personally took over the direction of "Amt Mil." The Abwehr's posts and subposts within Germany, its occupied territories, and neutral countries were placed under control of the RSHA, as were its front line units. The Abwehr's budget and a number of its civilian and military personnel were also transferred to the RSHA. (41)

Subsequent investigation of the July 20, 1944, assassination attempt implicated some of the more highly placed Abwehr officials. Canaris and Hansen were both arrested and executed. Hans Oster, the head of the Abwehr's Central Group, who had been relieved of his Abwehr command late in 1943 because of his ties to the resistance, and his friend Hans von Dohnanyi, the civilian lawyer who had occupied the desk next door, were arrested and executed. Colonel Wessel von Freytag-Loringhoven who took over command of Abwehr II from General Lahousen, and Colonel Werner Schrader, a member of the Abwehr's Special Duties Section and of the Oster Circle, committed suicide. (42) Many other individuals either directly or indirectly involved with the Abwehr were implicated in the assassination attempt, arrested, and executed. What was left of the Abwehr after its absorption into the RSHA was struck a severe blow. Ultimately all of Germany's intelligence functions were assigned to the uncoordinated, chaotic, and by then tottering Nazi party. 
NOTES FOR CHAPTER VII

1. Federal Bureau of Investigation, "Simon Emil Koedel Espionage-G" (Washington, D.C., June 8, 1945), 1. 2. Kahn, Hitler's Spies, 333; FBI, "Simon Emil Koedel," 1 .

3. Farago, Game of Foxes, 630.

4. Ibid., 630 .

5. FBI, "Simon Emil Koedel," 1. Foxes, 630 .

6. Kahn, Hitler's Spies, 333; Farago, Game of 7. FBI, "Simon Emil Koedel," 1. Foxes, 631 .

8. Kahn, Hitler's Spies, 333; Farago, Game of

9. Kahn, Hitler's Spies, 333.

10. Farago, Game of Foxes, 632.

11. Ibid., 632 .

12. Kahn, Hitler's Spies, 333.

13. Ibid., 334-335; FBI "Simon Emil Koedel," 4.

14. FBI. "Simon Emil Koedel," 2; Kahn, Hitler's Spies, 334 .

15. Farago, Game of Foxes, 634-635.

16. Ibid., 635.

17. Ibid., 637; Kahn, Hitler's Spies, 334.

18. Farago, Game of Foxes, 638.

19. Ibid., 638 .

20. Ibid., 639; Kahn, Hitler's Spies, 335 . 
21. Kahn, Hitler's Spies, 335; Farago, Game of Foxes, $639-640$.

22. FBI, "Simon Emil Koedel," 3; Kahn, Hitler's Spies, 334; Farago, Game of Foxes, 636.

23. Farago, Game of Foxes, 636 .

24. FBI, "Simon Emil Koedel," 2, 3.

25. Farago, Game of Foxes, 633-634.

26. Ibid., 628; FBI, "Simon Emil Koedel," 2, 4; New York Times (October, 24, 1944), 25:8.

27. FBI, "Simon Emil Koedel," 1; Farago, Game of Foxes, 628,630 .

28. Kahn, Hitler's Spies, 335.

29. New York Times (February 8, 1945), 21:3, (February 16, 1945), 25:7, (February 20, 1945) 21:7; FBI, "Simon Emil Koedel," 4.

30. Höhne, Canaris, 539.

31. Ibid., 538.

32. David Irving, Hitler's War (London, 1977). 604.

33. Kahn, Hitler's Spies, 268; Höhne, Canaris, 550.

34. Kahn, Hitler's Spies, 268-269; Höhne, Canaris, 553-554; Gehlen, The Service, 94.

35. Cave Brown, Bodyguard of Lies, 456; Höhne, Canaris, 557, 561 .

36. John Toland, Adolf Hitler (New York, 1976, 1977), 1121; William L. Shirer, The Rise and Fall of the Third Reich (New York, 1960, 1962), 1393.

37. Höhne, Canaris, 563, 564, 565.

38. Abshagen, Canaris, 242.

39. Höhne, Canaris, 580.

40. Ibid., 580-581.

41. Ibid., 559; Kahn, Hitler's Spies, 270-271. 
42. Hohne, Canaris, 571; Gehlen, The Service, 28. 


\section{CHAPTER VIII}

\section{A LAST EFFORT}

There was a final episode of German espionage activity against the United States following the Abwehr's fall. This last mission was arranged under the auspices of the office of walter Schellenberg, who directed RSHA VI and "Amt Mil"--the remnants of the Abwehr. In late 1944, RSHA VI landed two agents off the coast of Maine. Their job was to obtain technical and scientific data from the United States--anything that would aid Germany's deteriorating military condition.

By 1944, Germany's war effort was in trouble. Its ally Italy had surrendered unconditionally on september 23, 1943, following the Allied invasion of the Italian mainland. Italy had then joined the Allies as a co-belligerent, and a combined force of British and Americans was fighting its way up the Italian boot. In the east, the soviets were on the offensive and were recapturing much of the territory they had lost earlier to the Germans. Germany was vitally in need of technical intelligence to help its faltering military situation, and Schellenberg knew the best place to acquire advanced data on ships, airplanes, rockets, engineering, and scientific discoveries was in America. The German agencies were receiving some information from the 
United States and South America, but it was not enough and the delays were too long. (1)

Apparently the first request for a mission to the United States had come to Schellenberg from Joachim von Ribbentrop, the German Foreign Minister. Ribbentrop wanted a source in the United States to gather and relay American political intelligence back to Germany, and also a source to judge the effect of German radio propaganda on the American public during the 1944 presidential campaign. (2) Schellenberg's priorities for the mission were different, but as an end result, both men wanted the same thing: the landing of an agent or agents in the United States, subsequent infiltration into American life, and finally the acquisition of a great deal of important intelligence for Germany •

Schellenberg was ever aware of the abortive eight-man Abwehr mission to the United States in 1942, and sought to overcome the frailties inherent in an operation of this type, which he felt the Abwehr had overlooked or succumbed to. The choice of agents was a particularly important element; a decision that had to be made with the utmost care and consideration. This vital process was put in the hands of SS Major Theodor Paeffgen who directed Group D of RSHA VI and supervised spying in America. Paeffgen looked for candidates within the files of the Nazi Party's "Auslandsorganisation" or AO, the organization which united all party members abroad.(3) The "Auslandsorganisation" 
also served as an information source about the countries in which various members lived, since each AO leader forwarded a monthly report concerning the economic, military, and political situation of his respective host country. (4) The two men finally selected were William Colepaugh and Erich Gimpel.

Colepaugh was born in Niantic, Connecticut, in 1918. An American of American-born parents, Colepaugh's only tie to Germany came from his mother's immigrant parents. He attended the Massachusetts Institute of Technology where he studied naval architecture and engineering before flunking out in early $1941 .(5)$

After the war began in Europe, Colepaugh revealed a fascination with Nazi Germany and its methods of war that was, perhaps, not unusual for a young man of his age and interests. However, Colepaugh went further than necessary and began acquainting himself with German consulate officials in Boston, and the crew of the German tanker "Pauline Friedrich" that was tied up at Battery Wharf in Boston.

In late May, 1940, Customs Guards stationed around Battery Wharf reported to the FBI that Colepaugh had made statements indicating an interest in going to Germany to study engineering, and also that he was unhappy in the United States and wished to leave the country.(6) When Colepaugh was asked why he wanted to spend time with Germans on a German ship, he replied that they were "nice" to him 
and that he liked them better than people in the United States. (7) Because Colepaugh made many visits to the "Pauline Friedrich," invited crew members to his home in Niantic, and for a time lived and worked on board the tanker, the FBI initiated an investigation of him in June, $1940 .(8)$

While still at school, Colepaugh received a great deal of propaganda material from the German consul in Boston, Herbert Scholz, and from German news agencies in New York. In addition, he made a number of visits to the Boston Consulate in early 1941.(9)

On May 7, 1941, Colepaugh went to Canada, shipped aboard the British freighter "Reynolds," and sailed for Scotland. Colepaugh had evidently been enlisted by Scholz to bring back information on British convoys, however by the time he returned, all German consulates in America had been closed.(10) In September, 1941, he shipped out of New York on the Swedish ship "Anita," which sailed for Rio de Janeiro. In Buenos Aires he was unable to get permission from authorities there to join the German army.(11)

Back in America in July, 1942, a warrant was issued for Colepaugh's arrest for violating the Selective Training and Service Act. Colepaugh had failed to keep his draft board advised of his address, which was a violation of federal law and came under the jurisdiction of the FBI. (12) He was advised by the United States Attorney in Boston that he would not be prosecuted if he volunteered for military 
service; consequently Colepaugh enlisted in the Navy. However, by June of 1943, the FBI was advised that Colepaugh had been honorably discharged "for the good of the service." Undoubtedly Colepaugh's pro-German sympathies had not been popular with his fellow apprentice seamen. (13)

In January, 1944, Colepaugh obtained employment on the Swedish liner "Gripsholm," and dutifully informed his draft board. In Lisbon, Colepaugh jumped ship and went to the German consulate to find out if he could go to Germany. Colepaugh explained his relationship with the former German consul in Boston, his trip for Scholz to gather information on British convoys, and his desire to join the German army. A few days later Colepaugh was cleared to go to Germany. (14) RSHA VI was very interested in Colepaugh; the fact that he was American-born would make him almost undetectable as a spy in the United States. However, there was always the chance that, like Sebold, Colepaugh was a double agent working for the Americans. Schellenberg was determined to avoid the mistakes of the Abwehr, and had Paeffgen spend months checking Colepaugh's story, attitude, and actions. Finally after numerous interviews, Colepaugh was told he would be placed at the disposal of the Reich's Security Service, and was sent to the SD's spy school at The Hague in June, $1944 .(15)$

The second selection for the RSHA VI mission to America was Erich Gimpel. Gimpel was born in Merseburg near Berlin in 1910. From 1935 to 1942 he worked in Lima, Peru, 
for Telefunken, the German radio corporation. While in Lima, Gimpel was asked by a German attaché to observe the ships and cargoes going in and out of port. When diplomatic relations between Peru and Germany were severed, Gimpel was interned as an enemy alien. He was repatriated to Germany by way of the United States, going first to Camp Kennedy in Texas and then to Jersey City, New Jersey. Gimpel sailed on the Swedish vessel "Drottningholm" and arrived back in Germany August 1, 1942.(16)

After his return to Germany, Gimpel worked for a time designing radio transmitters. He also served as a courier for the Foreign office between Berlin and Madrid, and because of his knowledge of Spanish, was put to work translating into German technical information from Spanish newspapers and magazines. This work brought him to the attention of RSHA VI, and in the summer of 1944, Gimpel was asked to go to the United States as a spy.(17) According to David Kahn, author of Hitler's Spies, Gimpel at first refused to spy on America, but was finally persuaded when the SS interviewer warned him that if Germany lost the war, Gimpel would be forced to go to the Soviet Union because of his technical abilities. (18) Gimpel was sent to the spy school at The Hague where he trained with William Colepaugh. The spy school at The Hague was similar to the Abwehr school which had operated outside of Brandenburg. There Gimpel and Colepaugh learned to handle explosives and firearms. Both received a great deal of physical fitness 
training, and learned to ride a motorcycle. Political instruction was also included. Colepaugh was also trained in radio communication during his two month stay at the school.(19) Gimpel had much of the technical knowledge and training required and stayed only four weeks.

After their training at The Hague, Gimpel and Colepaugh returned to Germany where they were educated in photography--how best to use their Leica cameras and how to develop and print the pictures they took. They also studied how to reduce their negatives to microdots that could be hidden on any letter or envelope, and read only under a microscope. (20)

It was during the photography training that Colepaugh was told that he and Gimpel would be sent to the United States to gather information from American magazines, newspapers, books, and radio regarding airplanes, shipping, and rocket production. The two men were told to pay particular attention to anything in the engineering field.(21) Gimpel was instructed to build a radio by which all vital intelligence was to be sent to Germany. The code for sending radio messages was based on the advertising slogan on the Lucky Strike Cigarette package: "Lucky Strike Cigarettes--It's Toasted."(22) Mail drops in Lisbon and Madrid were to be used for the less essential material. In addition the men were provided with the names and whereabouts of twenty American prisoners-of-war in Germany. If Colepaugh or Gimpel needed to get in touch with Berlin, 
they were to address the letter to one of the prisoners, using invisible ink for the important message. These letters would be intercepted by German authorities and forwarded to RSHA VI. (23)

Both men were issued false papers, Colepaugh's in the name of "William C. Caldwell," and Gimpel's made out to "Edward George Green." Colepaugh received a birth certificate, a selective service registration card, a Selective Service classification card, discharge papers from the United States Navy, and a driver's license from Massachusetts. Gimpel's papers were substantially the same. They also received duplicate papers that they could fill out themselves if necessary. The mission was to last two years and some of the forms were predated for 1946. (24)

Gimpel and Colepaugh were given $\$ 60,000$ in American currency for their two year mission. Colepaugh had told the Germans that the cost of living in the United States had taken a "sharp turn upwards," and that a single man needed $\$ 15,000$ a year to live on. (25) Gimpel was also given approximately one hundred small diamonds to be used if they ran out of money, or if the currency given to them was no longer in use. (26)

Colepaugh and Gimpel left Kiel harbor on board the U-1230 in early October, 1944. They landed at Frenchman Bay, Maine, on November 29, 1944, and were in New York City by December 1, too late to make any judgements on the effect of German propaganda on the American presidential election. 
Once in New York City, the two German agents looked for an apartment in a building that was constructed without steel, where they could operate their short-wave radio. A suitable headquarters was found by December 8 , and radio parts were purchased for Gimpel to begin construction on a transmitter-receiver unit. The rest of the time they spent living it up in New York City on the RSHA's money. The Christmas season in New York provided a host of entertainments and neither of the two men seemed anxious to begin spying. (27)

Though Schellenberg had tried to take every precaution in organizing his first espionage operation to the United States, there occurred events that were simply beyond his control. On December 3, the British freighter "Cornwallis" was torpedoed off of Bar Harbor, Maine, just a few miles away from Frenchman Bay. The FBI was alerted since this sinking signified the presence of an enemy submarine close to the Maine coast and the possibility that it may have landed enemy agents. (28) During the FBI interviews of area inhabitants, Harvard Hodgkins, the son of a Deputy Sheriff, reported seeing two men walking away from the beach in the vicinity of Frenchman Bay on November 29. Hodgkins had told his father about the two men, but their subsequent investigation of the road and the beach turned up nothing.(29) Another resident of the area had seen two men about a mile from where Hodgkins reported his sighting. The FBI found nothing on the beach but were able to determine 
that the two men did not ride the bus, make any long distance calls, or buy train tickets in the area. Unbeknownst to the FBI, Gimpel and Colepaugh had stumbled across a taxi and had hired it for the ride into Bangor, Maine. (30)

The sinking of the British ship and the warning it provided to the FBI was an incident Schellenberg could not have foreseen, but he was reasonably confident in Paeffgen's ability to predict the actions of the men the leader of Group $D$ had recruited for the mission to the United States. Unfortunately for Paeffgen and Schellenberg, their mission experienced the same sort of failure as the Abwehr mission of 1942. The flaw was William Colepaugh.

During the waging of the last German offensive of the war--the Battle of the Bulge--Colepaugh decided to walk out on Erich Gimpel, taking their cumulative cash with him. It is not clear why Colepaugh left, nor whether his intention was to turn himself in to the authorities. For whatever the reason, on December 21, Colepaugh left Gimpel at a men's clothing store, took the suitcase containing the money and his own traveling bag (both of which Gimpel had the keys for) to the baggage room at Grand Central Station. He checked in at the expensive St. Moritz Hotel on Central Park South for two days and continued to live it up in the city. On December 23, Colepaugh went to see Edmund Mulcahy, an old friend from school, and confessed his entire story, showing the false identification papers and the large amount of 
money as proof.(31) Colepaugh and Mulcahy spent the next few days together and discussed informing the authorities. Finally on December 26, Mulcahy called the FBI and arranged for a special agent to come to his house and hear Colepaugh's story. Colepaugh was taken into custody and the hunt for Gimpel began. (32)

Gimpel retrieved the suitcases Colepaugh left at Grand Central station by first claiming he had lost the claim tickets and then producing the keys for the bags. Gimpel guessed correctly that Colepaugh would probably stay in New York and enjoy the night life before leaving the city, and would not want to carry around suitcases that he could not easily open. (33)

Gimpel left the apartment he had shared with Colepaugh and moved twice to different hotels. In the meantime FBI agents were combing the city armed with an accurate description of Gimpel supplied by Colepaugh. Gimpel was picked up by agents of the FBI on December 30,1944 , at a newsstand in Times square.(34)

Erich Gimpel and William Colepaugh were charged with violation of the 82 nd Article of War--spying--and conspiracy. Their trial by Military Commission began on February 6, 1945, at Governor's Island, New York. On February 14, the Commission found both men guilty and sentenced them to death by hanging. President Truman later commuted their sentences to life imprisonment. (35)

When Gimpel and Colepaugh came ashore at Frenchman Bay 
on November 29,1944 , they entered a country that was in profound contrast to Nazi Germany, a country whose inhabitants felt their war was all but won. In America there were no bombed-out cities, no real austerity, and nothing like the SS or Gestapo that dominated German life. True, rationing was a part of the war years in United States, but the country was well-off by German standards, and was reveling in the success of the war effort, of which the entire nation felt it shared a part. Though many experienced losses, the country as a whole celebrated the Allied push at Normandy in June, 1944, and the liberation of Rome and Paris in June and August.

The Russians were racing through eastern Europe, and in October, 1944, captured Belgrade in Yugoslavia. The only surprise was the Battle of the Bulge in December, and American troops at Bastogne stopped this last German offensive. The war in the Pacific was also going well for the United States. New Guinea was conquered in september, 1944. In the Battle of Leyte Gulf in October, the Japanese fleet was virtually wiped out by the U.S. Navy, and by February 23, 1945, the liberation of the Philippines was complete.

Consequently, much of the fear that had been generated by the threat of German spies and saboteurs prior to the war was absent in the winter of 1944-45, though up through the war's end and even after, the American people retained the strongly reinforced image of the merciless, monocled 
Prussian, and the diabolical, completely bad Nazi as a threat to the free world. Spy hysteria most assuredly waxed and waned in direct relation to America's conduct and success in the war, though by late 1944 Americans were no doubt more vigilant about enemy spies. A good example of this was the conduct of Harvard Hodgkins who spotted Gimpel and Colepaugh walking up from the beach in the early morning of November, 29. After passing the men on the highway he followed their footprints in the snow down to the shore, aware of the concern about spies landing on the coast. Later he was able to impart this information to the FBI. (36) In fact, shortly after the arrest of Gimpel and Colepaugh, J. Edgar Hoover recognized Hodgkins' action and stated:

The only way that the agencies charged with the internal security of this country can cope with the problem is to ask for the cooperation of every loyal American in reporting any suspicious characters to the FBI. (37)

The responsibility of coordinating the fight against enemy espionage rested with the FBI, and it is true that the Bureau worked hard correlating information against those reported to be disloyal to the United States, and searching out those "enemies of democracy." The Bureau's director was anxious that the $F B I$ retain its paramount position as America's chief spy catcher. After the capture of Gimpel and Colepaugh, Hoover cautioned Americans to be ever on the alert:

A great many persons have the idea that the war is over and that now we can let down the bars. This case and some other recent matters should dispel 
that idea. It is very clear that the German government is carrying on an intensive program of training espionage and sabotage agents and sending them into the Western Hemisphere. The German government at least, does not think the end of the war is near. (38)

However, by this last winter of the war, the danger of enemy infiltration seemed to have passed, or was at least more readily accepted and thus easier to handle and eliminate. The "salad" days enjoyed by the Abwehr's agents for a short time in the late 1930's were never to be repeated, probably due more to the quality of agents the German intelligence service recruited than to the vigilance of the FBI. It is certain that Nazi Germany underestimated the United States militarily and did itself great damage. It is easier to understand then, that the Third Reich's leaders possibly overestimated the capabilities and skill of the agents selected to work against the United States, and at the same time underrated the American security organs. Thus German agents sent to the United States after December, 1941, were never able to gain a substantial footing. Schellenberg and Paeffgen had hoped to avoid the sort of disasters that had befallen the Abwehr's team of saboteurs in 1942, but they did not. Despite all of the intense checking the RSHA did on William Colepaugh and the precautions they took against his being a double agent, Colepaugh duplicated George Dasch's actions of 1942 and betrayed the operation to the FBI. Consequently the mission that had involved so much preparation, materials, and money 
while the Third Reich struggled through the last months of the war in the end accomplished nothing. 
NOTES FOR CHAPTER VIII

1. Kahn, Hitler's Spies, 6 .

2. Ibid., 5 .

3. Ibid., 7 .

4. Ibid., 7, 98; International Military Tribunal, Trial of the Major War Criminals Before the International Military Tribunal (Nuremburg, 1949; Reprint ed., New York, 1971), $\mathrm{X}: 20,31-32,42$.

5. Federal Bureau of Investigation, "William Curtis Colepaugh, Erich Gimpel, Espionage" (Washington, D.C., September 20, 1954), 2; Kahn, Hitler's Spies, 10.

6. FBI, "William Curtis Colepaugh," 1.

7. Ibid., 2 .

8. Ibid., 2 .

9. Ibid., 2, 4; Kahn, Hitler's Spies, 7.

10. FBI, "William Curtis Colepaugh," 4; Kahn, Hitler's Spies, 7-8.

11. Kahn, Hitler's Spies, 8 .

12. Ibid., 8; FBI, "William Curtis Colepaugh," 4.

13. FBI, "William Curtis Colepaugh," 5; New York Times (January 2, 1945), 6:2.

14. FBI, "William Curtis Colepaugh," 5-6.

15. Ibid., 7 .

16. Ibid., 24 .

17. Ibid., 24 .

18. Kahn, Hitler's Spies, 11.

19. Ibid., 11; FBI, "William Curtis Colepaugh," 7, 8.

20. FBI, "William Curtis Colepaugh," 8. 
21. Ibid., 8-9; Kahn, Hitler's Spies, 13.

22. FBI, "William Curtis Colepaugh," 10.

23. Ibid., 9.

24. Ibid., 10; Kahn, Hitler's Spies, 14.

25. FBI, "William Curtis Colepaugh," 11.

26. Ibid., 10 .

$34: 1$.

27. Ibid., 13; New York Times (February 8, 1945),

28. FBI, "William Curtis Colepaugh," 14.

29. Ibid., 15; Kahn, Hitler's Spies, 18, 20.

30. FBI, "William Curtis Colepaugh," 12, 15; Kahn, Hitler's Spies, 20 .

31. FBI, "William Curtis Colepaugh," 16; New York Times (February 9, 1945), 9:1; Kahn, Hitler's spies, 24.

32. FBI, "William Curtis Colepaugh," 17.

33. Ibid., 21; Kahn, Hitler's Spies, 23.

34. FBI, "William Curtis Colepaugh," 22-23; Kahn, Hitler's Spies, 25.

35. FBI, "William Curtis Colepaugh," 26.

36. Ibid., 15 .

37. New York Times (January 2, 1945), 6:2.

38. Ibid., (January 2,1945 ), 6:2. 


\section{CHAPTER IX}

\section{RESPICE FINEM}

In his final testament, Adolf Hitler wrote, "The war with America is a tragedy; illogical, devoid of fundamental reality."(1) Indeed, the entire German campaign against the United States was a tragedy--for the Third Reich. It reflected an almost nearsighted determination on the part of Adolf Hitler to ignore America as a world power, and the prospect and impact of American intervention on behalf of the Allies. Hitler disregarded the lessons of 1917, and through December, 1941, maintained his antagonistic attitude toward the United States, while appearing indifferent to America's power, its hostility to the Third Reich, and its growing attachment to the Allies.

In 1941, Germany's war expanded from its fight against lonely Britain to the invasion of the Soviet union, and finally to its declaration of war on the United States on December 11, 1941. The Third Reich went from an offensive war which it largely controlled, to tactics that pitted it against two of the largest and most powerful countries in the world. Hitler's ideology however, allowed him to maintain an unrealistic belief that Germany's purity and innate supremacy would ultimately triumph over the combined forces of his enemies. 
Hitler alone was supreme in the Third Reich, controlling the state, the government, the party and the armed forces. His power was dictatorial, and he was extremely jealous of the authority he held. Power and influence in Nazi Germany was gained by seeking Hitler's favor, encouraging intrigue and rivalry between individuals and organizations. Intelligence work suffered from the competition for power generated between agencies. No agency or department had the full support of its peers. Hitler was the final arbiter in the use or disposal of material

gathered by the intelligence groups. His view of America as being inconsequential to the war in Europe contributed to the inefficient espionage and sabotage campaigns in the United States.

The Abwehr--Germany's military intelligence organ, and the office most involved in espionage against the United States--had to struggle for its very existence within Hitler's Germany. In addition, despite the fact that it was engaged in gathering intelligence from the United States from a relatively early time in the Third Reich's history, information obtained by the Abwehr did not influence Hitler, nor did his plans hinge on what the Abwehr learned.

Hitler's designs for Germany were firmly founded in his own ideology, one of the main points being acquisition of land in Eastern Europe as a solution to the problem of German living space, or "Lebensraum." Hitler's foreign policy reflected an obsession with Eastern "Lebensraum," 
observable in the annexation or "Anschluss" of Austria, the takeover of Czechoslovakia, the invasion of Poland, and of the Soviet Union. Each step he took was part of a calculated plan to expand the Reich eastward, often at the expense of all other considerations. Throughout the Reich's years of peace and the early years of war, Hitler's offensive policies proved successful. With these initial conquests following his schedule, Hitler felt foreign intelligence was superfluous, and had no need of the knowledge collected by his various espionage groups. As David Kahn, author of Hitler's Spies, said of the Führer: "He intended to impose his will on other countries. Their fate would lie in his hands. For this he needed no intelligence." (2)

Hitler disregarded or ignored any contradictions of his beliefs or interference in his plans. The Abwehr's work in America and the results produced did not, and would not have, dissuaded Hitler from his goals, nor would it have changed what he felt were his intuitive truths. Hitler claimed the United States was weak, calling it "a feeble country with a loud mouth."(3) He underestimated its military potential, and stressed American isolationism, social division, economic problems, and "racial decay" in order to discount a strong American role in Europe. In 1938, Hitler replied to a question regarding the effect of American intervention in a European war with the statement that, the United States was incapable of conducting war. (4) 
Hitler was convinced that America was an inferior country; an unrealistic belief, but one suited to his purpose. It left him free to deal with the problem of "Lebensraum" and the Reich's march east.

Hitler's world was central Europe, and it cannot be emphasized enough that areas outside his world were essentially outside his scope of interest and concern. America was one of those nations that was of no vital importance to Hitler. That is not to say that the whole of Germany felt America was weak and of little consequence. On the contrary, German diplomats in the United States consistently warned the Reich's political leadership of American hostility toward Germany's domestic and foreign policies, while emphasizing America's industry, its potential military strength, and its close ties with Britain. However, these cautious truths made little impression on Hitler and those close to him. This failure on the part of Germany's leaders, particularly Adolf Hitler, to properly evaluate and use information from the United States hampered the German intelligence system. It is not unlikely then that these general beliefs held by the Führer regarding the United States trickled down through the structure of the Third Reich and its people, including perhaps, its intelligence organizations. The Abwehr had to have been exposed to these arrogant distortions of Hitler's, and the RSHA certainly was.

Naturally the Abwehr was interested in information 
from the United States, but its methods and operations were often conducted in clear defiance of the American security system. In the spring of 1941, Hitler was spouting rhetoric that affirmed a German-American conflict would find Germany "...vastly superior, and that quite apart from the fact that the German soldier naturally ranks high above the Americans."(5) In a similar vein, many Abwehr agents and their spymasters felt espionage activities in the United States could be conducted safely and with little interference from "those stupid Americans."(6)

The accomplishments of Germany's agents in America did not live up to expectations of the spymasters in the Third Reich, nor did the information ferreted out by these agents affect the final outcome of the war. The Abwehr enjoyed some success in its early years in America, but by and large the Abwehr was forced to deal with a number of abortive and unsuccessful missions, and caused by agents who were singularly unequipped for intelligence work. When the Nazi Party in the form of the RSHA took over German foreign intelligence and worked against America the results were the same.

Competition and rivalry between agencies within the Third Reich, the Abwehr's own internal problems and diverse loyalties, the fact that military intelligence was not at first a priority for the Third Reich's leaders, and the underestimation of the United States, made the Abwehr lax and sometimes caused distortions in its intelligence; thus 
its espionage work in America suffered. This is clearly indicated by the caliber of a number of the agents engaged for espionage work against the United States: Guenther Rumrich, the consummate failure who joined the Abwehr via a letter and an ad in the New York Times, who was caught because of a foolish error and promptly informed on everyone he knew; George Dasch, the waiter selected for a sabotage mission, who betrayed his co-agents and their assignment in the hopes of becoming an American hero; william Colepaugh, the disgruntled American who thought it would be fun to spy for Germany, who energetically spent more than $\$ 400$ a week of the RSHA's funds, and after less than a month in the United States, turned himself and his partner in to the FBI. (7) And finally, in the epitome of poor screening, the Abwehr's enlistment of William sebold as a spy, whose clandestine work for the FBI coupled with the lack of security precautions on the part of the German agents working in the United States, led to the largest number of mass arrests of alien spies in American history.

Obviously the choice of these men as agents was not successful for German intelligence in the long run; instead their selection proved self-defeating, for first the Abwehr and later the RSHA. Additionally, their performance did Iittle to fit Hitler's much touted view of Aryan supremacy, or his belief in the unwavering loyalty and sense of duty imbued in those of German blood. Thus many of those enlisted by German intelligence for espionage work against 
the United States were probably the least qualified, or the least likely, to serve as spies.

From the beginning, National Socialist Germany and the United States were separated by a wide ideological gulf, and neither country's inhabitants were especially reticent about expressing their views about each other. Hitler, for example, was always very clear. To him the United States was :

...a decayed country, with problems of race and social inequality, of no ideas.... My feelings against America are those of hatred and repugnance; half Judaized, half negrified with everything built on the dollar.(8)

According to Hitler, Americans had "the brains of a hen," and the country itself was "a Jewish rubbish heap."(9)

The Americans were equally blunt. Anti-Nazi demonstrations in the United States were mentioned regularly in dispatches from the German embassy in Washington to Berlin, beginning shortly after the installation of Hitler as Chancellor in January, 1933. By March, Ambassador Prittwitz reported on the already unfavorable reaction in the United States toward National Socialism.(10) Outbursts ranged from protests against German anti-Semitism to a mock murder trial of Hitler in New York City.(11)

After 1938, most of America's hostility was directed toward what was viewed as Germany's aggressive foreign policy. In the United States, Germany was seen as the moral enemy, ideologically at odds with American principles, intent on ultimately conquering the world. This view was 
reinforced by a number of America's governmental and political leaders. Treasury Secretary Henry Morgenthau and Interior Secretary Harold Ickes were noted for their anti-German feelings and statements, and secretary of War Henry Stimson and Secretary of Navy Frank Knox were avowed interventionists.(12) In 1940, President Roosevelt stated that Hitler and Germany aimed at "the complete domination of the world."(13) Secretary of State cordell Hull described Hitler in late 1941 as:

The most devastating and all-pervading conqueror and destroyer in the last thousand years and we believe there is no geographical limit whatsoever to his infamous plans. (14)

These views, accompanied by a certain amount of effective exaggeration, were passed on through the media to the American public who, in general, came to share these same opinions.

Almost from its inception as the reigning power in Germany, National Socialism was perceived by many Americans as a threat to the United States. Germany was the adhesive that bound the Axis together, ties which automatically put the anti-fascist countries of the world--the United States included--on the defensive. As the Third Reich maintained its aggressive policies, many Americans began to visualize a dividing line between themselves and the Nazis, which not only differentiated between their ideologies, but also emphasized what were seen as moral differences--good and evil, freedom and slavery, democracy and fascism. It 
naturally followed that Americans, for the most part, were adamantly against the importation of National Socialism to the United states, though the country had its share of pro-Nazi groups. High-visibility organizations like the German-American Bund, taken in the same context as statements by Hitler and others which stressed the international solidarity and innate loyalty to the Reich of those of German blood, violated American sensitivities toward foreign ties and contributed to the fear of fifth column activities.

Though the United States had maintained a policy of isolationism after the First World War, Americans found that their self-imposed quarantine did not render their country inviolate from the activities of German espionage agents. The first arrests of Nazi spies in the United States in 1938 illuminated this most clearly. Americans had determined that their country would remain apart from the problems of Europe and the rest of the world, but naturally the Abwehr did not recognize this position and showed no compunction in its attempts to delve into America's secrets. Thus the involvement of the Abwehr in America and its justifiable refusal to acknowledge American "isolationism," brought the United States closer in principle and position to other potential enemies of Germany, and accelerated America's progress away from its self-imposed segregation.

The arrest of Guenther Rumrich in 1938 was the first outward manifestation of Nazi aggression directed toward the 
United States. It was at this point that all the fears harbored by Americans for the Nazis seemed justified. The fact that espionage agents were sent to the United States seemed proof enough of the Third Reich's intentions. Suddenly Nazi spies seemed to be everywhere; sent to weaken America, to steal its secrets, to sabotage its industry, to topple the country from the inside. And their numbers were apparently enormous. For every spy arrested, Americans were told there were hundreds, even thousands more still at large.

In 1941, the American public was again apprised of the presence of German espionage agents in their midst. This time more than forty individuals involved in two spy rings were arrested by the FBI. Fear of sabotage increased during the war years. In 1942 and 1944, in two different operations, the Nazis landed agents on America's eastern coast in an attempt to infiltrate spies and saboteurs into the population. Both missions were ultimately exposed from within.

In each of the spy cases described, publicity and media coverage were very strong, exceeding by far the actual importance and success of the individuals involved. In the late 1930's and the early 1940's, the views of President Roosevelt's administration and the American public regarding German National Socialism were amplified through the media, and after the detection of the first German spies, publicity exaggerated the skills and numbers attributed to the network 
of German espionage agents in the United States. This, in turn, led to unrealistic fears regarding German espionage in America, which translated into hysterical calls to the FBI describing German spies communicating through the water faucets, putting ground glass into food, parachuting into the hills, or sending cryptic messages all over the country by means of flashing lights. (15)

The American public was swayed by their conceptions of the Nazis and what was believed to be the Nazi plan for the United States. While the spies arrested were often prejudiciously portrayed due to their "fascist" beliefs and their results belittled, there remained the fear among Americans of those German spies who had not yet been caught. These undetected agents were those who generated the most apprehension throughout the country. They were the ones who would start the fires, poison the water supplies, disseminate disease cultures and germs in populated areas, and blow up vital transportation centers.

Unfortunately, most Americans were not informed of the ratio of success to failure for German spies and saboteurs in the United States between 1935 and 1945. Essentially, they knew only that agents of the Third Reich had been caught, and that each patriotic American had to be constantly on the defensive to guard against the insidious German spy. Of course this belief was strengthened by what the average American read and watched in films, and was mitigated slightly only in the last months of the war when 
victory was in sight.

The accomplishments of German espionage agents in America did not merit such fears; Americans themselves exaggerated the success and stature of the German spy, an image unfortunately reinforced somewhat by the media, and by the government. In the Third Reich, the value of gathered intelligence was determined by how the information was evaluated. Ironically enough, vital intelligence could be lost or disregarded if improperly judged. In the same vein, it could be said that what was perceived as the success of German spying in America was determined less by the concrete achievements of the agents than by how the entire espionage threat was evaluated by the American people. In the end, like Hitler, the Abwehr, and the RSHA, the American public became the victims of their own distortions and misconceptions. 
1. James V.Compton, The Swastika and the Eagle (Boston, 1967), 266.

2. Kahn, Hitler's Spies, 529.

3. Gerhard Weinberg, "Hitler's Image of the United States," American Historical Review, LXIX.4:1017 (July, $1964)$.

4. Compton, The Swastika and the Eagle, 33.

5. Documents on German Foreign Policy, D:XI:524.

6. Farago, Game of Foxes, 580 .

7. New York Times (January 2, 1945), 6:2. FBI found $\$ 56,574.61$ out of the original $\$ 60,000$.

8. Compton, The Swastika and the Eagle, 17.

9. Ibid., 17.

10. Documents on German Foreign Policy, C: I:175.

11. Ibid., C:II:552.

12. Compton, The Swastika and the Eagle, 73, 89.

13. Ibid., 255.

14. Ibid., 255.

15. Irwin, what You Should know, 207, 213-214. 


\title{
A LIST OF WORKS CONSULTED
}

\author{
GUIDES AND CATALOGS
}

American Historical Association, Committee for the Study of War Documents. Guides to German Records Microfilmed at Alexandria, Virginia. Washington, D.C.: National Archives, 1958-1964. 40 volumes.

American Historical Association, Committee for the Study of War Documents. List of Archival References to Material in the German Foreign Ministry Archives. Whaddon Hall, Buckinghamshire, England: American Historical Association, 1958.

Kent, George. A Catalogue of Files and Microfilms of the German Foreign Ministry Archives 1920-1945. Stanford, California: Hoover Institution Press, 1966-1972. 4 volumes.

National Archives and Records Service, General Services Administration. Guides to German Records Microfilmed at Alexandria, Virginia. Washington, D.C.: National Archives and Records Service, 1964-1982. 40 volumes.

National Archives Trust Fund Board. Catalog of National Archives Microfilm Publications. Washington, D.C.: National Archives Trust Fund Board, 1974. Supplement, 1982 .

Weinberg, Gerhard. Guide to Captured German Documents: Supplement. Washington, D.C.: National Archives and Records Service, 1959.

\section{PRIMARY SOURCES}

PUBLISHED DOCUMENTS AND OFFICIAL PUBLICATIONS

British War Bluebook. New York: Farrar and Rinehart, 1939.

Documents on American Foreign Relations. Volumes I-VI Boston Massachusetts: World Peace Foundation, 1939-1945; Volumes VII-VIII Princeton, New Jersey: Princeton University Press, 1947-1948. 
Documents on German Foreign Policy 1918-1945. Series C (1933-1936), series D (1937-1941), Washington, D.C.: United States Department of State, 1949-1983.

Documents on the Events Preceding the Outbreak of the War. Berlin: German Foreign Office, 1939; New York, 1940.

Federal Bureau of Investigation. "Anastase A. Vonsiatsky, Espionage." Washington, D.C.: Federal Bureau of Investigation, August $8,1945$.

Federal Bureau of Investigation. "Captain Laurent Hendrikus Johannes Brackx, Espionage-Censorship." Washington, D.C.: Federal Bureau of Investigation, July 31, 1945.

Federal Bureau of Investigation. "Carlos Vejarano $Y$ Cassina, Espionage-G." Washington, D.C.: Federal Bureau of Investigation, July 4, 1944 .

Federal Bureau of Investigation. "Ernst Fritz Detler Heinrich Lehmitz, Espionage-G." Washington, D.C.: Federal Bureau of Investigation, October 22, 1943.

Federal Bureau of Investigation. "Frederick Joubert Duquesne, et al Espionage." Washington, D.C.: Federal Bureau of Investigation, May 5, 1953.

Federal Bureau of Investigation. "Re: George John Dasch, with aliases, et al Sabotage." Washington, D.C.: Federal Bureau of Investigation, November 14, 1942.

Federal Bureau of Investigation. "Herbert Karl Friedrich Bahr, Espionage." Washington, D.C.: Federal Bureau of Investigation, September 21, 1942 .

Federal Bureau of Investigation. "Kurt Friedrich Ludwig, Espionage-G." Washington, D.C.: Federal Bureau of Investigation, March 11, 1943.

Federal Bureau of Investigation. "Simon Emil Koedel, Espionage-G." Washington, D.C.: Federal Bureau of Investigation, June $8,1945$.

Federal Bureau of Investigation. "Washington Glendale Spiegelberg, Espionage." Washington, D.C.: Federal Bureau of Investigation, January 7, 1943.

Federal Bureau of Investigation. "Wilhelm Albrecht von Pressestin Genant von Rautter, Espionage." Washington, D.C.: Federal Bureau of Investigation, July 11, 1945 . 
Federal Bureau of Investigation. "William Arthur Schuler, Espionage-G." Washington, D.C.: Federal Bureau of Investigation, August 29, 1942.

Federal Bureau of Investigation. "William Curtis Colepaugh, Erich Gimpel, Espionage." Washington, D.C.: Federal Bureau of Investigation, September 20, 1954.

Inaugural Addresses of the Presidents of the United States From George Washington 1789 to Richard Milhous Nixon 1973. Washington, D.C.: Government Printing Office, $\frac{1974}{1974}$.

International Military Tribunal. Trial of the Major War Criminals Before the International Military Tribunal. Nuremberg: 1947-1949; New York: AMS Press Inc., 1971. 42 Volumes.

Irving, David, ed. Breach of Security. The German Secret Intelligence File on Events Leading to the Second World War. London: William Kimber and Co., 1968.

National Archives and Records Service. Records of the German Armed Forces High Command (Oberkommando der Wehrmacht/OKW), Part VI, Amt Ausland Abwehr. National Archives Microfilm Publication T77.

National Archives and Records Service. Records of the German Foreign Ministry. National Archives Microfilm Publication T120.

Nazi Conspiracy and Aggression. Washington, D.C.: Government Printing Office, 1946. 10 Volumes.

United States Department of State. Foreign Relations of the United States: Diplomatic Papers. Washington, D.C.: Government Printing Office, 1955-1969. Volumes for $1938-1945$.

United States Navy Department, Office of Naval Intelligence. Espionage-Sabotage-Conspiracy: German and Russian Operations 1940-1945. Washington, D.C.: Apri1, 1947.

United States Navy Department, Office of Naval Intelligence, Op 32-E. German Naval Intelligence. Washington, D.C.: October 15, 1946 .

United States State Department, European Affairs Division. National Socialism: Basic Principles, Their Application by the Nazi Party's Foreign Organization, and the Use of Germans Abroad For Nazi Aims. Washington, D.C.: Government Printing Office, 1943. 
Federal Bureau of Investigation. "William Arthur Schuler, Espionage-G." Washington, D.C.: Federal Bureau of Investigation, August 29,1942 .

Federal Bureau of Investigation. Erich Gimpel, Espionage."

"William Curtis Colepaugh, Bureau of Investigation, September 20, 1954.

Inaugural Addresses of the Presidents of the United States From George Washington 1789 to Richard Milhous Nixon 1973. Washington, D.C.: Government Printing office, $\overline{1974}$.

International Military Tribunal. Trial of the Major War Criminals Before the International Military Tribunal. Nuremberg: 1947-1949; New York: AMS Press Inc., 1971. 42 Volumes.

Irving, David, ed. Breach of Security. The German Secret Intelligence File on Events Leading to the Second World War. London: William Kimber and Co., 1968.

National Archives and Records Service. Records of the German Armed Forces High Command (Oberkommando der Wehrmacht/OKW), Part VI, Amt Ausland Abwehr. National Archives Microfilm Publication T77.

National Archives and Records Service. Records of the German Foreign Ministry. National Archives Microfilm Publication T120.

Nazi Conspiracy and Aggression. Washington, D.C.: Government Printing Office, 1946. 10 Volumes.

United States Department of State. Foreign Relations of the United States: Diplomatic Papers. Washington, D.C.: Government Printing Office, 1955-1969. Volumes for 1938-1945.

United States Navy Department, office of Naval Intelligence. Espionage-Sabotage-Conspiracy: German and Russian Operations 1940-1945. Washington, D.C.: April, 1947.

United States Navy Department, office of Naval Intelligence, Op 32-E. German Naval Intelligence. Washington, D.C.: October 15, 1946 .

United States State Department, European Affairs Division. National Socialism: Basic Principles, Their Application by the Nazi Party's Foreign Organization, and the Use of Germans Abroad For Nazi Aims. Washington, D.C.: Government Printing Office, 1943. 
Dodd, William. Ambassador Dodd's Diary. New York: Harcourt Brace Jovanovich, 1941.

Gehlen, Reinhard. The Service: Memoirs of General Reinhard Gehlen. Translated by David Irving. New York: World Publishing, 1972 .

Hitler, Adolf. Mein Kampf. Translated by Ralph Manheim. Boston, Massachusetts: Houghton Mifflin Co., 1943.

Hitler, Adolf. Hitler's Secret Conversations. Translated by Norman Cameron and R.H. Stevens. New York: Octagon Books, 1972 .

Hull, Cordell. Memoirs of Cordell Hull. New York: Macmillan Co., 1948.

Israel, Fred, ed. The War Diary of Breckenridge Long. Lincoln, Nebraska: University of Nebraska Press, 1966.

Schellenberg, walter. The Labyrinth: Memoirs of Walter Schellenberg. Translated and edited by Louis Hagen. New York: Harper Brothers, 1956; Hitler's Secret Service. Translated by Louis Hagen. New York: Jove Publications, 1977.

SECONDARY SOURCES

CONTEMPORARY PUBLICATIONS

Aeronautical Chamber of Commerce of America, Inc. The Aircraft Yearbook for 1935. New York: Aeronautical Chamber of Commerce of America, 1935.

Carlson, J.R. Undercover. New York: E.P. Dutton and Co., 1943.

Chase, Allan. Falange; The Axis Secret Army in the Americas. New York: G.P. Putnam's Sons, 1943.

Chrysler Corporation-Dodge Division. Instruction Manual: Dodge Trucks $1 / 2$ Ton $4 \times 4$ Chassis, Built for United States Army. Detroit, Michigan: Chrysler Corp., 1941 .

Farren, Harry. Sabotage. How To Guard Against It. New York: National Foremen's Institute, Inc., 1940. 
Gollomb, Joseph. Armies of Spies. New York: Macmillan Co., 1939.

Hynd, Alan. Passport to Treason. New York: Robert M. MCBride and Co., 1943.

Irwin, William. What You Should know About Spies and Saboteurs. New York: W.W. Norton and Co., 1943.

Matthews, Blaney. The Specter of Sabotage. Los Angeles, California: Lymanhouse, 1941.

Page, Victor Lieut. Colonel Air Corps Reserve. Airplane Inspection Repair and Maintenance. New York:

Aeronautical Digest Publishing Corporation, 1937.

Riess, Curt. Total Espionage. New York: G.P. Putnam's Sons, $19 \overline{41 .}$

Rowan, Richard. Secret Agents Against America. New York: Doubleday, Doran and Co., 1939.

Sayers, Michael and Kahn, Albert. Sabotage! The Secret War Against America. New York: Harper and Brothers, 1942 .

Steinbeck, John. The Moon is Down. New York: The Viking Press, Inc., 1942 .

World Committee for the Victims of German Fascism. The Brown Network. New York: Knight Publications, $\frac{19}{19} 36$.

\section{GENERAL WORKS}

Abshagen, Karl Heinz. Canaris. Translated by Alan Broderick. London: Hutchinson and Co., Ltd., 1956.

Blum, John Morton. $\mathrm{V}$ Was For Victory. New York: Harcourt Brace Jovanovich, 1976.

Brissaud, Andre. Canaris. Translated by Ian Colvin. New York: Grosset and Dunlap, 1974.

Cave Brown, Anthony. Bodyguard of Lies. New York: Harper and Row, 1975.

Colvin, Ian. Master Spy. New York: McGraw-Hill Book Co., 1951.

Compton, James V. The Swastika and the Eagle. Boston: Houghton Miffin Co., 1967. 
Davidson, Eugene. The Trial of the Germans. New York: Macmilian Co., 1966 .

Farago, Ladislas. The Game of Foxes. New York: David McKay Co., $19 \overline{71 .}$

Friedman, Saul. No Haven For the Oppressed. Detroit, Michigan: Wayne State University Press, 1973.

Frye, Alton. Nazi Germany and the American Hemisphere. New Haven, Connecticut: Yale University Press, 1967.

Hilton, Stanley E. Hitler's Secret War in South America, 1939-1945. Baton Rouge, Louisiana: Louisiana state University Press, 1981.

Hoffmann, Peter. The History of the German Resistance 1933-1945. Translated by Richard Barry - Cambridge, Massachusetts: The MIT Press, 1977.

Höhne, Heinz. Canaris. Translated by J. Maxwell Brownjohn. New York: Doubleday and Company, Inc., 1979 .

Hohne, Heinz. The Order of the Death's Head. Translated by Richard Barry. New York: Coward-McCann, Inc., 1970 .

Irving, David. Hitler's War. New York: Viking Press, 1977.

Kahn, David. Hitler's Spies. New York: Macmillan Publishing Co., Inc., 1978.

Masterman, J.C. The Double-Cross System in the war of 1939-1945. New Haven, Connecticut: Yale University Press, 1972 .

Morse, Arthur D. While Six Million Died. New York: Random House, 1967.

Nicholls, A.J. Weimar and the Rise of Hitler. New York: St. Martin's Press, 1968.

Rachlis, Eugene. They Came To Kill. New York: Random House, 1961.

Satterfield, Archie. The Home Front: An Oral History of the United States 1941-1945. Chicago, Illinois: Playboy Press, 1981.

Shirer, William L. The Rise and Fall of the Third Reich. 
New York: Simon and Schuster, 1960; Crest Books, 1962.

Toland, John. Adolf Hitler. New York: Doubleday and Company, Inc., 1976; Ballantine Books, 1977.

wighton, Charles and Peis Gunter. Hitler's Spies and Saboteurs. New York: Henry Holt and Co., 1958.

Wyman, David S. Paper Walls. Massachusetts: University of Massachusetts Press, 1968.

\section{ARTICLES AND NEWSPAPERS}

Aswell, Edward C. "The Case of the Ten Nazi Spies," Harper's Magazine, CLXXXV.1105:1-21 (June, 1942).

"Caught in the Act," Time, XXXVIII.13:14 (September 29, 1941).

"Expanding Espionage," Literary Digest, CXXI.22:13-14 (May $30,1936)$.

"FBI Smashes Spy Ring," Life, XI.26:24-27 (December 29, 1941).

"German Aerial Cameras Spy Out the Military Secrets of Britain," Life, VII.25:13-17 (December 18, 1939).

"German Espionage and Sabotage Against the United States," ONI Review, I.3:33-38 (January, 1946).

"Hitler's Advocate," Time, LVII.9:32 (February 26, 1951).

"Is America Infested With Nazi Spies," Christian Century, LV.44:5 (November 2, 1938).

New York Times. 1938-1945.

"Spy Business," Time, XXXII.20:19-20 (November 14, 1938).

"Spy Scare," Literary Digest, CXXII.4:5 (July 25, 1936).

"The Big Spy Scare," Newsweek, XI24:10-11 (June 13, 1938).

"The 8 Nazi Spies Should Be Put To Death," Life, XIII.2:32-33 (July 13, 1942).

"The Saboteurs and the Court," New Republic, CVII.6:159-160 (August 10, 1942).

Trefousse, Hans. "Failure of German Intelligence in the 
United States, 1935-1945," Mississippi Valley

Historical Review, XLII.1:84-100 (June, 1955).

Weinberg, Gerhard. "Hitler's Image of the United States," American Historical Review, LXIX.4:1006-1021 (July, 1964). 